\title{
Documenting the Business Register and Related Economic Business Data
}

by

\author{
Bethany DeSalvo \\ U.S. Census Bureau
}

Frank F. Limehouse

U.S. Census Bureau

Shawn D. Klimek

U.S. Census Bureau

\begin{abstract}
CES 16-17 March, 2016
The research program of the Center for Economic Studies (CES) produces a wide range of economic analyses to improve the statistical programs of the U.S. Census Bureau. Many of these analyses take the form of CES research papers. The papers have not undergone the review accorded Census Bureau publications and no endorsement should be inferred. Any opinions and conclusions expressed herein are those of the author(s) and do not necessarily represent the views of the U.S. Census Bureau. All results have been reviewed to ensure that no confidential information is disclosed. Republication in whole or part must be cleared with the authors.

To obtain information about the series, see www.census.gov/ces or contact Fariha Kamal, Editor, Discussion Papers, U.S. Census Bureau, Center for Economic Studies 2K132B, 4600 Silver Hill Road, Washington, DC 20233, CES.Papers.List@census.gov. To subscribe to the series, please click here.
\end{abstract}




\begin{abstract}
The Business Register (BR) is a comprehensive database of business establishments in the United States and provides resources for the U.S. Census Bureau's economic programs for sample selection, research, and survey operations. It is maintained using information from several federal agencies including the Census Bureau, Internal Revenue Service, Bureau of Labor Statistics, and the Social Security Administration. This paper provides a detailed description of the sources and functions of the BR. An overview of the BR as a linking tool and bridge to other Census Bureau data for additional business characteristics is also given.
\end{abstract}

We thank Brandy Yarbrough, Carrie Hill, and Eddie Salyers from the Economic Directorate. We also like to thank Kristen McCue and CJ Krizan for their thoughtful guidance and Jim Davis, Chris Galvan, Danielle Sandler, Melissa Banzhaf, John Sullivan and Rachelle Hill for their assistance.

For comments or questions about this working paper, contact the corresponding author, Shawn Klimek via email at Shawn.D.Klimek@census.gov or by telephone at 301-763-2861. 


\section{Introduction}

The Center for Economic Studies (CES) partners with stakeholders within and outside the U.S. Census Bureau to improve measures of the economy and people of the United States through research and innovative data products. As part of this mission, CES maintains micro-level data on business establishments and the population of individuals and households in the United States. CES is also responsible for archiving Census data, collected under Title 13, that are commingled with Federal Tax Information (FTI), in agreement with the National Archives and Records Administration. Social scientists at the Census Bureau, as well as external researchers in the academic community, federal agencies and other research organizations, improve upon the data and conduct research using them to benefit Census Bureau programs.

In 1968, the Office of Management and Budget directed the Census Bureau to develop and maintain the Business Register (BR) on behalf of federal statistical agencies. The BR is a current and comprehensive database of business establishments and companies in the United States. Since 1972, it has been the central repository of statistical and administrative record data providing key information to the federal statistical system. All active employer business establishments with payroll at any time during the past three years, or with an indication that the business expects to hire in the future, are included in the database. This paper will address only the employer part of the BR. For information on non-employers, see www.census.gov/econ/nonemployer. 
The BR or Standard Statistical Establishment List ${ }^{1}$ (SSEL) contain FTI protected under Title 26, which applies to statistical work conducted using the Census Bureau’s collection of Internal Revenue Service (IRS) FTI data on households and businesses. The BR information is confidential and access is restricted to persons specially sworn to uphold the confidentiality provisions of Titles 13 and 26.

Access to micro-level data is advantageous to external researchers in many ways, such as the analysis of heterogeneous behaviors of firm and employment dynamics, and for linking to external data. Another notable advantage is the fine level of geographic specificity. Census Bureau microdata on persons, households, and businesses typically have geographic identifiers at the census tract or block level (for more information see Davis and Holly, 2006). However, the BR also includes the physical and mailing address of individual businesses. Because the BR can be linked to other Census Bureau data, the scope of potential research broadens. Such low levels of geocoding also allow for the linkage of Census Bureau business data to other (non-Census) micro-level data that have the same geographic identifiers such as mailing or physical address. The BR is a valuable source for several key measures of business activities such as payroll, total employment, sales, and industrial classification. Additional business characteristics and measures of activity are available from other economic censuses or survey data. ${ }^{2}$ The Longitudinal Business Database (LBD) is often used alongside the BR by researchers who need longitudinal links for businesses (see the Linkages section below as well as Jarmin and Miranda, 2002, for further details about the LBD).

\footnotetext{
${ }^{1}$ Prior to 2002, these data were referred to as the Standard Statistical Establishment List (SSEL).

${ }^{2}$ For a full list of available business data, see https://www.census.gov/ces/dataproducts/.
} 
The primary functions of BR data include sourcing and maintaining the frames for economic surveys and censuses and serving as a central repository for administrative records information about businesses. The $\mathrm{BR}$ is also directly aggregated to generate measures for the County Business Patterns, ZIP Business Patterns statistical series and Business Dynamics Statistics (Haltiwanger, Jarmin \& Miranda, 2009). ${ }^{3}$ For external researchers, the BR and LBD are the backbone of business and economic research. They serve as the definitive list of all business establishments and firms in the United States and allows for the linkage of establishments and firms across economic surveys and censuses.

This paper proceeds as follows. Section 2 provides a brief description of the sources of data in the BR. Section 3 describes the statistical units within the dataset. Section 4 presents the variables available for use in the BR. Section 5 gives examples of how these data can be linked to internal and external datasets. Section 6 provides concluding remarks.

\section{Sources of data}

The BR is a comprehensive database that contains a record for each known legal establishment that is located in the U.S. or its territories and has information on employees, except employers classified as private households. It is updated using information from several federal agencies, including the IRS, the Bureau of Labor Statistics (BLS), the Social Security Administration (SSA) and the Census Bureau. The IRS provides the Business Master File (BMF) ${ }^{4}$, which includes the IRS-assigned Employer Identification Number (EIN). The EIN is used to identify all companies known

\footnotetext{
${ }^{3}$ www.census.gov/ces/dataproducts/bds /publications.html

4 http://www.irs.gov/pub/irs-pia/bmf-pia.pdf
} 
to the IRS. These data are used to identify business births. The IRS also provides payroll tax returns and business income tax returns. The payroll tax returns are used to identify business and organizational employers that file the Employer’s Quarterly Federal Tax Return, IRS Form 941 series (944 replaces the 941 for small businesses ${ }^{5}$ ) and agricultural employers that file the Employer's Annual Tax Return for Agricultural Employees, Form 943 series. Both types of returns identify taxpayers by EIN and provide total employment for the pay period including March 12 and information on the tax period covered. The business income tax returns provide basic measures of business receipts or revenue and assets annually. Most returns also provide a principal business activity (industrial) classification.

The SSA and the BLS provide critical data elements to the BR. The SSA provides information on new businesses and organizational taxpayers that file an application for EIN, Form SS-4. Form SS-4 data include EIN, industry, or North American Industry Classification System (NAICS) codes, geographic information, estimated employment, and other classification/status indicators. The BLS maintains a separate list of business establishments, known as the Business Establishment List (BEL). These data are based on information collected at the state level in connection with unemployment insurance programs. Each quarter, BLS matches the BEL to Census Bureau supplied EINs and provides establishment-based information on location, industry classification codes, and ownership type, particularly for new and small businesses (Fairman et al, 2008).

The Census Bureau contributes to the BR through multiple data sources. The Company Organization Survey (COS), also known as the Report of Organization Survey,

\footnotetext{
${ }^{5}$ Small businesses are defined as having less than $\$ 1,000$ in tax liability, equivalent to under $\$ 4,000$ in annual payroll. 944 reporting started for the 2006 year in 2007 as a requirement for small businesses. The 944 form does not have fields for entry of employment totals.
} 
is an annual survey performed specifically for the purpose of maintaining BR information about multi-unit establishments' current organization and operating information. The COS covers about 30 percent of the multi-unit companies and a small selection of business entries that have not been identified as multi-units but are likely to be as indicated by administrative records. ${ }^{6}$ This survey allows for the delineation of the relationships among multiunit enterprises and their EIN entities and establishments. The survey also captures the end-of-year operating status, employment for the pay period including March 12, first quarter payroll, and annual payroll for each establishment. Since 2011, the COS also included inquiries about enterprise-level operating revenue and net sales, revenue from royalties and license fees for rights to use intellectual property, and contract manufacturing activities. These enterprise-level inquiries are published through the Enterprise Statistics Program (ESP). For more information on ESP, see http://www.census.gov/econ/esp/.

The Economic Census, conducted every 5 years (covering years ending in ' 2 ' and '7'), is a large sample of the U.S. business establishment population and, therefore, a valuable source of information for BR maintenance. From October through December 2012, forms were sent out to nearly 4 million establishments, representing all U.S. locations and industries. For most economic census sectors and programs, all multi-unit establishment firms were surveyed. The economic census also surveys a sample of small, single-establishment employers. The Economic Census and COS programs are closely integrated, ensuring comprehensive BR updates. During intercensal years, the Annual Survey of Manufactures (ASM) is integrated with the COS and provides valuable annual

\footnotetext{
${ }^{6}$ The certainty sample cutoff was changed from 250 to 500 employees to increase the number of companies available for the target sample starting in 2013.
} 
feedback on coverage and classification information for enterprises and their manufacturing establishments. The ASM is often the first to identify new multiunit establishments in the manufacturing sector, changes in ownership, and updated address information. Figure 1 shows how these data are processed within Census Bureau.

\section{Figure 1. Data Processing Flow for the Business Register}
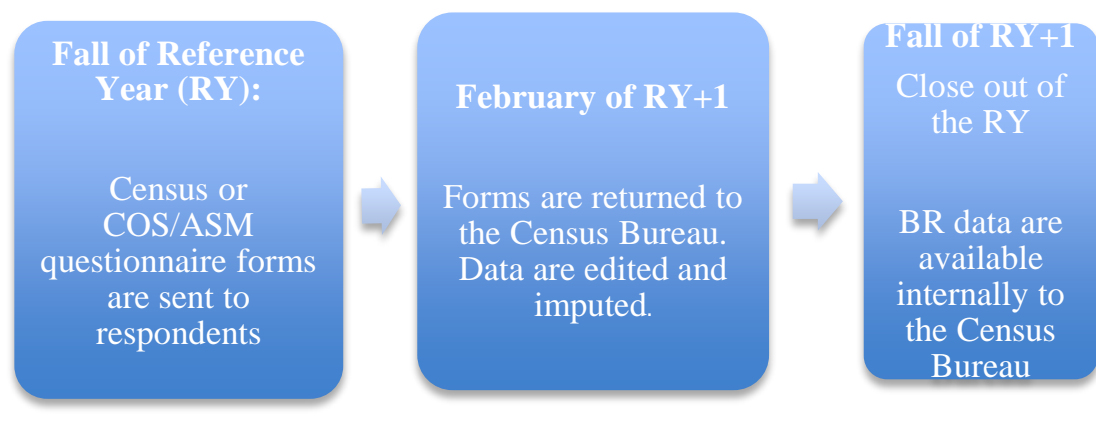

Spring of RY+2

BR-based public data products are released \& FSRDC snapshot is

released to approved projects

Figure 1 shows the flow of data processing for the BR. In the fall of the Reference Year (RY), questionnaire forms are sent to the respondents. The forms are due early the following year $(\mathrm{RY}+1)$. Data collection is allowed to continue into the summer of RY+1 and then the data are edited and imputed. A final snapshot of the BR is created and then made available within CES, in the fall of the RY+1. The next spring and summer $(\mathrm{RY}+2)$, the County Business Patterns (CBP) data and other data products that use the BR are released. Approved external users of the BR could expect access to the BR data in the spring of each year for data reported 2 years prior. For example, in the spring of 2015 access may be granted to the BR data for 2013.

The key variables of interest in the BR include payroll, employment and sales and revenue. Payroll is the most completely populated of the three and sales and receipts is the least. For the most recent years of data, the payroll fields have almost no missing 
data, while employment has about 15-20 percent missing and sales and receipts have 2550 percent missing for single unit firms. For multi unit firms, the most recent BR has 1020 percent missing for payroll and employment, and for sales and receipts most fields are missing. The missing sales and receipts data are missing mainly because multiunit firms do not typically file separate tax forms for each establishment location. The tax records usually aggregate payroll and employment across locations. The Census Bureau uses the COS information to impute these fields. These imputed sales and receipts data are available to approved users.

The sources of these key data as well as the NAICS and firm structure data are listed in Table 1. Examples of these forms are given in the appendix.

Table 1. Sources of Business Register Data for Key Variables

\begin{tabular}{|l|c|c|c|c|}
\hline $\begin{array}{l}\text { Key Activity } \\
\text { Variables }\end{array}$ & Census Bureau & IRS & BLS & SSA \\
\hline Payroll & $\begin{array}{c}\text { Economic Census, } \\
\text { COS, ASM }\end{array}$ & Forms 941, 943, 944 & & \\
\hline Employment & $\begin{array}{c}\text { Economic Census, } \\
\text { COS, ASM }\end{array}$ & Forms 941, 943, 944 & & SS4 \\
\hline $\begin{array}{l}\text { Sales \& } \\
\text { Receipts }\end{array}$ & $\begin{array}{c}\text { Economic Census, } \\
\text { COS, ASM }\end{array}$ & $\begin{array}{c}1120 \text { (corporations)/1065 } \\
\text { (partnerships)/990 (select tax } \\
\text { exempt organizations) Business } \\
\text { Income Tax Returns*7 }\end{array}$ & & \\
\hline NAICS & $\begin{array}{c}\text { Economic Census, } \\
\text { COS, ASM }\end{array}$ & $\begin{array}{c}\text { BMF, 1120 (corporations)/1065 } \\
\text { (partnerships)/990 (select tax } \\
\text { exempt organizations) Business } \\
\text { Income Tax Returns }\end{array}$ & BEL & SS4 \\
\hline Firm Structure & $\begin{array}{c}\text { Economic Census, } \\
\text { COS, ASM }\end{array}$ & $\begin{array}{c}\text { 851 Business Income Tax Returns } \\
\text { (n) }\end{array}$ & & \\
\hline
\end{tabular}

The Census Bureau is continuously processing data for the Business Register as demonstrated in Table 2.

\footnotetext{
${ }^{7}$ The 1040 schedule $\mathrm{C}$ is filed for sole proprietorships, which is out of scope of this paper. Data on these businesses can be found in the non-employer data. See: www.census.gov/econ/nonemployer.
} 
Table 2. Economic Administrative Records Files: Frequency and Record Count

\begin{tabular}{|c|c|c|}
\hline Item & Frequency of Updates & $\begin{array}{c}\text { Total Number of Records } \\
\text { Annually }\end{array}$ \\
\hline BMF Annual & Annual & 24 million \\
\hline BMF supplements & Monthly & 18 million \\
\hline $941 / 943$ & Weekly & 23 million \\
\hline $\begin{array}{c}1040 \text { Business Income Tax } \\
\text { Returns }\end{array}$ & Weekly & 8 million \\
\hline $\begin{array}{c}1120 / 1065 / 990 \text { Business } \\
\text { Income Tax Returns }\end{array}$ & Weekly & 1.8 million \\
\hline $\begin{array}{c}\text { SSA Business Births (IRS } \\
\text { Form SS-4) }\end{array}$ & Monthly & 1.2 million \\
\hline BLS industry codes & Quarterly & 0.5 million \\
\hline $\begin{array}{c}\text { 851 Business Income Tax } \\
\text { Returns }\end{array}$ & Bi-annual & \\
\hline \hline
\end{tabular}

\section{Statistical Unit Definitions}

An establishment or plant is the primary unit in the BR. The establishment is a single physical location where business transactions take place and for which payroll and employment are located. An enterprise or firm is an economic unit comprising one or more establishments under common ownership or control. That is, the enterprise is the highest-level parent company that controls more than 50\% interest in its affiliated establishments. A single-unit firm owns or operates only one establishment. Single-unit firms contain information primarily from administrative records, while multi-unit firm data are greatly enhanced with survey data. ${ }^{8}$ A multi-unit firm owns or operates two or more establishments.

A single-unit firm's primary identifier is its EIN. The IRS issues the EIN and the firm uses it as an identifier to report its taxes. All employer firms are required to have at least one EIN and only one firm can use a given EIN. Because a single-unit firm has only

\footnotetext{
${ }^{8}$ Many single-unit firm industry codes are derived from the Economic Census because NAICS codes from administrative records data may need updating. The Census Bureau is typically the first agency to implement new versions of NAICS, and the economic census vehicle informs other agencies.
} 
one establishment, there is a one-to-one relationship between the firm and the EIN. Thus, the firm, the EIN, and the establishment all reference the same physical location.

There is descriptive information for single-unit establishments in the BR, including geographic location, industry classification, payroll, and employment. Administrative records filed by EIN are the most common source of this information for single-unit establishments, with updates on geographic location and industry classification coming from Census Bureau surveys when available.

Multi-unit firms have a different structure that connects the firm with its establishments via the EIN. The BR allows for accurately identifying and maintaining the links among the component parts of a multi-unit firm, primarily through the census and survey data in Table 1. A multi-unit firm is associated with one or more EINs, and each EIN is associated with at least one establishment. A multi-unit firm consists of at least two establishments. Each establishment is associated with only one EIN ${ }^{9}$. Because of the possibility of one-to-many relationships, we distinguish between the firm, its EINs, and its establishments. The relationships among larger companies can be very complex involving many establishments and EIN units. See Figure 2 for an example of such a relationship.

\footnotetext{
${ }^{9}$ The BR data available to external researchers are a snapshot of the actual BR, which is a living database. Every establishment is associated with an EIN and Firm at years end. Mergers and acquisitions would be captured in the end of year portrait of the firm.
} 
Figure 2: Statistical Unit Relationship for a Small Multiple Establishment Firm

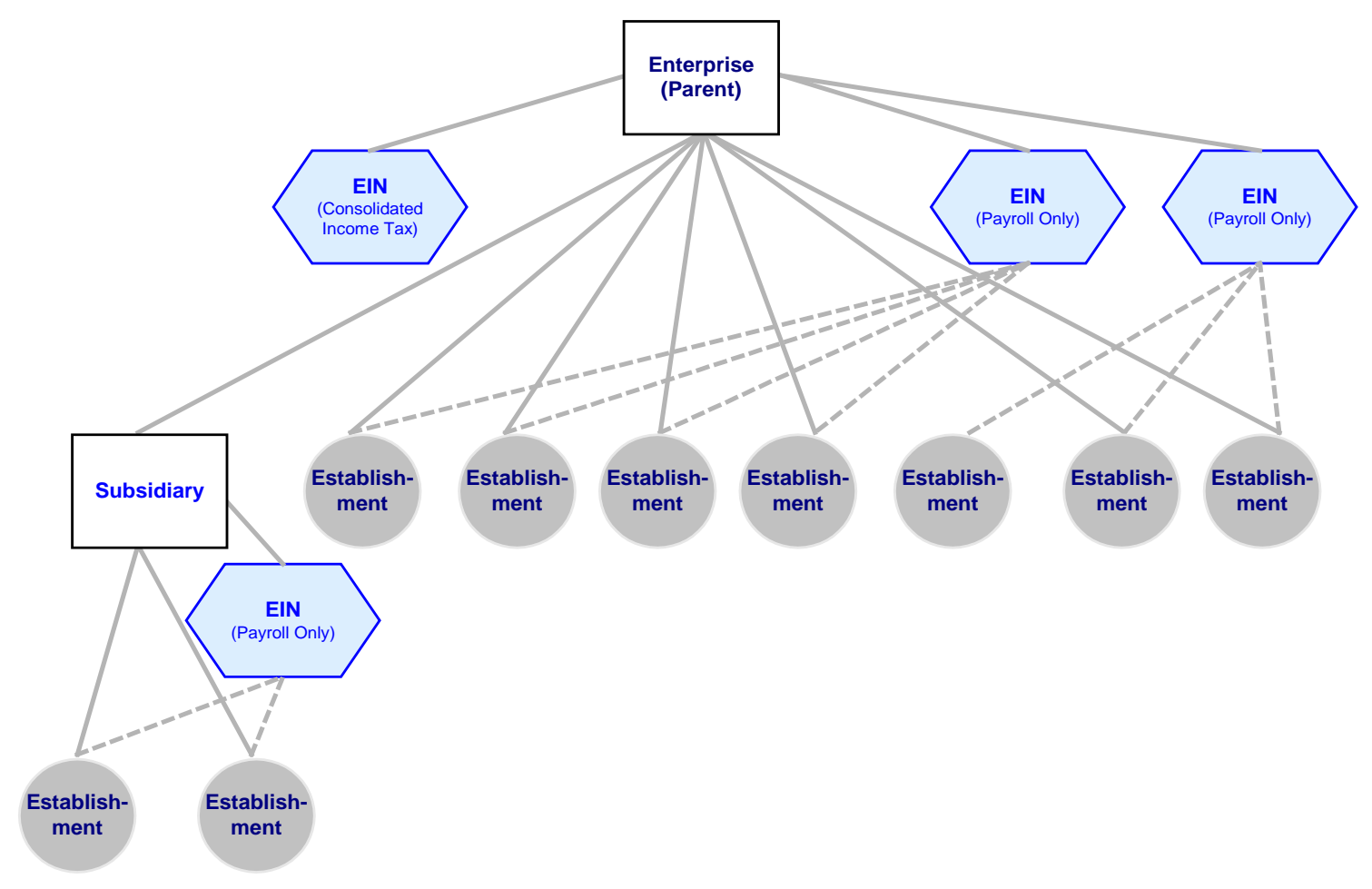

Along with the single-unit and multi-unit identifiers, each statistical unit in the BR also includes identifiers such as the EIN, the Census File Number (CFN), and the Enterprise ID. ${ }^{10}$ The CFN and Enterprise ID variables were created by the Census Bureau and have different roles. The CFN allows researchers to track survey responses to link the BR to the economic censuses and surveys within a given year as well as to identify if an establishment is multi- or single- unit. The Enterprise ID is a 10-digit number available to help researchers identify all establishments in a firm.

\footnotetext{
${ }^{10}$ There is also a historic firm identifier variable called "alpha" which is a six-digit version of the Enterprise ID. The alpha is used because some surveys did not make the switch to the Enterprise ID when the BR replaced the SSEL for the 2002 economic census.
} 


\section{Variables}

Variables in the BR (as well as most business databases maintained by the Census Bureau) generally fall into one of three main categories: 1) geography, 2) industry and organization classification, and 3) measures of activity.

\section{Geography}

The geographic indicators include a class of variables comprised of the physical location address and geographic classification. The physical location address variables include the (1) street address, (2) post office (city or town) name, (3) postal state abbreviation, and (4) ZIP Code. There are also variables providing information about a geographic classification. These variables are derived from automated geographic coding systems that classify every establishment with respect to each geographic area type, based on physical location address (ZIP code; postal state abbreviation; post office [city or town] name; and street address, if available). The attributes of the geographic classification variables include (1) States (2) Counties (3) Places (4) Census Tracts and Block Numbering Areas (block groups), and (5) Census Blocks. The State variable identifies all of the 50 states, the District of Columbia, and other statistically equivalent areas, including Guam, the Northern Mariana Islands, Puerto Rico, and the U.S. Virgin Islands. The Counties variable identifies counties and statistically equivalent areas, which include the District of Columbia, independent cities (e.g., in Virginia), and parishes in Louisiana and Alaska's boroughs/census areas. The Place classification identifies places for which the economic censuses compile statistics (generally, cities or towns having 2,500 inhabitants or more). Additionally, the Place variable identifies a balance-ofcounty area for all counties and statistically equivalent areas that are not coextensive with 
or wholly contained by separately identified places. ${ }^{11}$ The Census Tracts and Block Numbering Areas classification identifies statistical subdivisions of selected counties that are defined by a local committee of data users. Finally, the Census Blocks classification identifies statistical subdivisions of Census Tracts and Block Numbering Areas, generally bounded by physical features (e.g., streets or streams) and the boundaries of larger legal or statistical areas. The Census Tracts and Block Numbering Areas and the Census Blocks are not used for presentation of economic statistics, but serve as building blocks for larger geographic areas. Therefore, these fields may suffer from missing data. Starting in 2007, there are also some populated fields for latitude and longitude. The coverage by year ranges from 45-80 percent for the physical address field of individual establishments.

BR files have multiple fields for geographic information. The information on business location comes from a combination of administrative records and Census Bureau data. Most users are interested in the location of economic activity so the physical address is preferred.

\section{Industry and Organization Classification}

The BR classifies each establishment according to its primary business activity. The classifications are Standard Industrial Classification (SIC) based from 1974 to 2000 and NAICS based from 2001 to present. Efforts are currently underway to provide consistent NAICS codes back to 1974. Additionally, the BR classifies each multiunit enterprise according to its predominant business activity, defined as the industry group, which accounts for the largest share of employment. The industrial scope of the BR

\footnotetext{
${ }^{11}$ Places are subsets of states that do not necessarily obey county or tract lines. See: http://factfinder.census.gov/faces/nav/jsf/pages/using_factfinder.xhtml?page=census_geography
} 
depends partly on private versus government ownership or control. For privately owned entities, the BR systematically covers all industries except employers classified as private households, or NAICS 814. Taxpaying entities classified in other industries that are out of scope are included on the BR but generally are not resolved into establishment units unless they are part of a multi-establishment firm engaged in other activities that are in the scope of the Census Bureau's economic programs. The out-of-scope industries include: agriculture, forestry, fishing and hunting (NAICS 11); rail transportation (NAICS 482); the U.S. Postal Service (part of NAICS 491); elementary and secondary schools (NAICS 6111); colleges and universities (NAICS 6113); labor organizations (NAICS 81393); political organizations (NAICS 81394); religious organizations (NAICS 8131); and public administration (NAICS 92).

For government-owned/controlled entities, the BR covers only selected industries that are in-scope to the economic census, including: beer, wine, and distilled alcoholic beverages wholesalers (NAICS 4248); beer, wine and liquor stores (NAICS 4453); monetary authorities including central banks (NAICS 521); federal and federallysponsored secondary market financing (part of NAICS 522294); and hospitals (NAICS 622). The Census of Governments is conducted using the Government Master Address File maintained by the Census Bureau separately from the BR.

Organization classifications for operation type supplement industrial classifications by distinguishing basic operating types, such as wholesale trade and auxiliary establishments. The type-of-operation categories distinguish wholesale trade into (1) merchants (establishments selling primarily on their own account), (2) manufacturers' sales branches and offices (owned by multiunit manufacturing 
enterprises) and (3) wholesale agents, brokers, and commission merchants (selling primarily on a commission basis). For auxiliary establishments, the type-of-operation categories distinguish (1) multiunit establishments engaged primarily in performing management and (2) support services for other establishments of the same parent enterprise.

Classifications by legal form of organization are separated as (1) sole proprietorship, (2) partnership, (3) corporation, (4) cooperative association, (5) government-owned or controlled entity (covered only in selected industries), and (6) other (for example, trust, foundation, and estate).

Organizational classification for federal income tax status has each statistical unit classified as (1) subject to federal income taxes (generally profit-making) or (2) exempt from federal income taxes under Section 501 of the Internal Revenue Code (non-profit).

\section{Measures of Business Activity}

The BR records the following measures of business activity. First, the number of employees for the pay period including March 12 includes an aggregated total of full- and part-time employees, salaried corporate officers and executives, and persons on paid absences (for example, vacation or sick leave). This variable excludes proprietors and partners, volunteers, other persons in non-pay status, pensioners, persons working as independent contractors, and persons supplied by employee leasing or temporary help services. The BR also records the employment of establishments and EIN entities for the entire year (e.g. annual payroll). Additionally, the BR separately records current-year employment totals for enterprises, computed as the sum of all establishments and the sum of currently active establishments. 
The first quarter payroll variable consists of wages, salaries, bonuses, commissions, and other compensation paid to employees, including employee contributions to qualified pension plans and amounts paid to corporate officers and executives. This variable excludes amounts withdrawn from profits by proprietors and partners. The BR records the first quarter payroll of establishments and EIN entities in units of $\$ 1,000$ for the year; second, third, and fourth quarters are also available for single units and EIN entities.

The BR explicitly records the annual payroll of multiunit establishments in units of $\$ 1,000$. Additionally, an annual payroll figure may be derived as the sum of four quarters for single units and EIN entities. Each of the variables above includes a flag for imputations, which indicates missing values. These imputations are created using regression-based estimates that take seasonality into account.

The Value of Shipments, Sales, Receipts, or Revenue ${ }^{12}$ is an output measure comprising a set of four separate figures, the specific content of which varies somewhat depending on the type of income tax return that the business/organization files. These figures may include total revenue, gross income, operating receipts (gross receipts or sales less returns and allowances), interest income, and gross rents. The BR records these items in units of $\$ 1,000$ for single units and EIN entities as available. Statistical applications may derive a single output measure by combining components as appropriate (for example, interest income would be included only for certain financial industries and gross rents only for certain real estate industries).

\footnotetext{
${ }^{12}$ Most researchers who need the total value of receipts (or revenue/sales) variable will want to request that information from the appropriate Economic Census or survey (see Linkages Section below). Ongoing research at CES is analyzing the coverage and quality of the revenue variable in the BR.
} 
The BR also measures assets in units of \$1,000 for single units and EIN entities. The BR has incorporated yearly output and assets measures since 1994, and there is no imputation of missing values.

It is important to note that the ability to use data from the BR for research that is not central to sampling for the Economic Census is less known. Payroll and employment are the fields that are maintained as part of Census sampling operations. The content of these residual fields (assets, receipts, total value of shipments, sales, etc.) vary substantially by type of activity and legal structure of the firm according to different tax treatments (Haltiwanger et al., 2014). Because these particular data fields are not integral to the processing of the Economic Census operations they suffer from missing data.

\section{Linkages}

The BR can be linked to several categories of data. First, it can be linked to most of the other economic business data housed at the Census Bureau via the CFN or Firm ID. Second, it can be linked to proprietary data (e.g., Kauffman Firm Survey and Compustat data). Finally, it can be linked to micro-level data that have the same unit identifiers as the BR (e.g., EIN, business name and address). When non-Census Bureau data are to be linked with the BR, the Business/Organization name and address are often utilized. The BR can hold both the primary and secondary names, permitting identification of both legal and trade designations for businesses that support them (e.g., franchises). The physical address, however, is typically preferred over mailing address for the purposes of matching. 


\section{Census Bureau Data}

The Center for Economic Studies constructs and maintains the LBD. The LBD and $\mathrm{BR}$ are the most commonly used databases in economic research at CES and the Federal Statistical Research Data Centers $\left(\right.$ FSRDCs $\left.^{13}\right)$. These data allow for a longitudinal representation of business establishments across time. Essentially the LBD provides for the linkages of establishments in the annual BR files across years (see Jarmin and Miranda, 2002). One very important feature of the LBD is the retiming of establishment births. Establishments from small or new MU firms are usually identified in the Economic Census every five years. The LBD models these establishments' births and retimes them. Therefore, the LBD is an incredibly useful tool for research projects that require accurate measures and tracking of establishment births and deaths, firm affiliation across time, establishment and firm age, and industry and geographic movements across time.

The BR can also be linked to other U.S. Economic Censuses and surveys. While the BR and LBD contain basic measures on payroll and employment, more detailed business characteristics are available from other data sources. The Census of Manufactures, for example, contains additional information on manufacturing establishments' capital, energy expenditures, inputs and materials used in the production process, and information about products produced. Many researchers have used this level of detail about establishment characteristics. For example, Foster, Haltiwanger, and Syverson (2008) use producer-level quantities and derived establishment-level prices. Atalay (2012) analyzes variation in material prices paid for by manufacturing plants. Hsieh and Klenow (2009) use capital stock and the value of plants' machinery from the

\footnotetext{
${ }^{13}$ For more information on FSRDCs, see https://www.census.gov/ces/rdcresearch/
} 
Census of Manufactures to analyze resource misallocation and productivity. Similar levels of detail for other sectors are available in their respective Economic Censuses. For example, the Census of Service Industries contains information on revenues received from various components of the service operation. Moreover, some service establishments respond to "special inquiries" in their Census questionnaires that give additional level of detail regarding employees and how they specialize in the service operation. Garicano and Hubbard (2007), for example, use these data to analyze how vertical specialization in law firms impacts productivity. In addition to the Economic Census, the Census Bureau conducts surveys that are also linkable to the LBD and BR. Several of these are conducted on an annual basis, such as the Annual Survey of Manufactures, which allows for more frequent coverage of business characteristics than available in the Economic Census.

\section{External (non-Census Bureau) Data}

The Census Bureau has created and maintained crosswalk files to allow for further data linkages of Census data to data provided by other institutions and custodians of proprietary micro-level data ${ }^{14}$. One notable example is the Standard and Poor's Compustat database. These data contain financial information on publicly traded companies in the U.S. and abroad from public Securities and Exchange Commission (SEC) corporate filings. CES maintains a Compustat-SSEL bridge file that allows for the linkage of Compustat to other economic Census data. ${ }^{15}$ Census staff and RDC researchers have used these linkages to address several research questions. Davis,

\footnotetext{
${ }^{14}$ Crosswalks created for use with proprietary data are only provided to researchers who have access to the proprietary data through their own agreements.

${ }^{15}$ For more information see https://www.census.gov/ces/dataproducts/economicdata.html
} 
Haltiwanger, Jarmin, and Miranda (2006), for example, analyze business growth rates and employment shifts in publically traded versus privately held firms since 1976. Shadbegian and Gray (2005) combine Compustat data as well as micro-level data from the Environmental Protection Agency with Census Bureau data to analyze relationships between firm productivity and pollution emissions.

The name and address variables in the BR can be used by approved external researchers to match Census Bureau survey data to micro-level data from other agencies or institutions for which there are no maintained crosswalk files. Both the Census Bureau and the appropriate data custodian for the external data must approve using this matching methodology. Moreover, such projects utilizing both Census Bureau and external microlevel data are still required to demonstrate benefits to the Census Bureau. One example of this approach can be found in McElheran (2012) where the researcher matches records from the Harte Hanks Computer Intelligence database to the Census of Manufactures via business names and addresses in the BR. Another example is a match to the US Patent and Trademark Office (USPTO) patent data (Ufuk and Kerr, 2012; Balasubramanian and Sivadasan, forthcoming). Business names and addresses from the BR have also been used as a way to validate and enhance matching procedures using existing crosswalks to other data such as Compustat and the Longitudinal Employer Household Dynamics (LEHD) files.

In addition to using business name from the BR for matching purposes, researchers have used the business name variable for the purposes of identifying or crosschecking certain types of business establishments versus their industrial classification in the BR. Tolbert, Mencken, Riggs, and Li (2014) utilize business name from the BR to 
help identify locally-owned banks and credit unions in small rural areas. Current research performed by approved external FSRDC researchers uses similar approaches to assist in identifying agricultural operations.

Figure 3 shows how data can be linked together using the BR, LBD, and other micro-level business data. The BR is used to link data sources via the establishment ID, Firm ID, business name and address or EIN. 
Figure 3: Possible Linking Activity using the BR and LBD

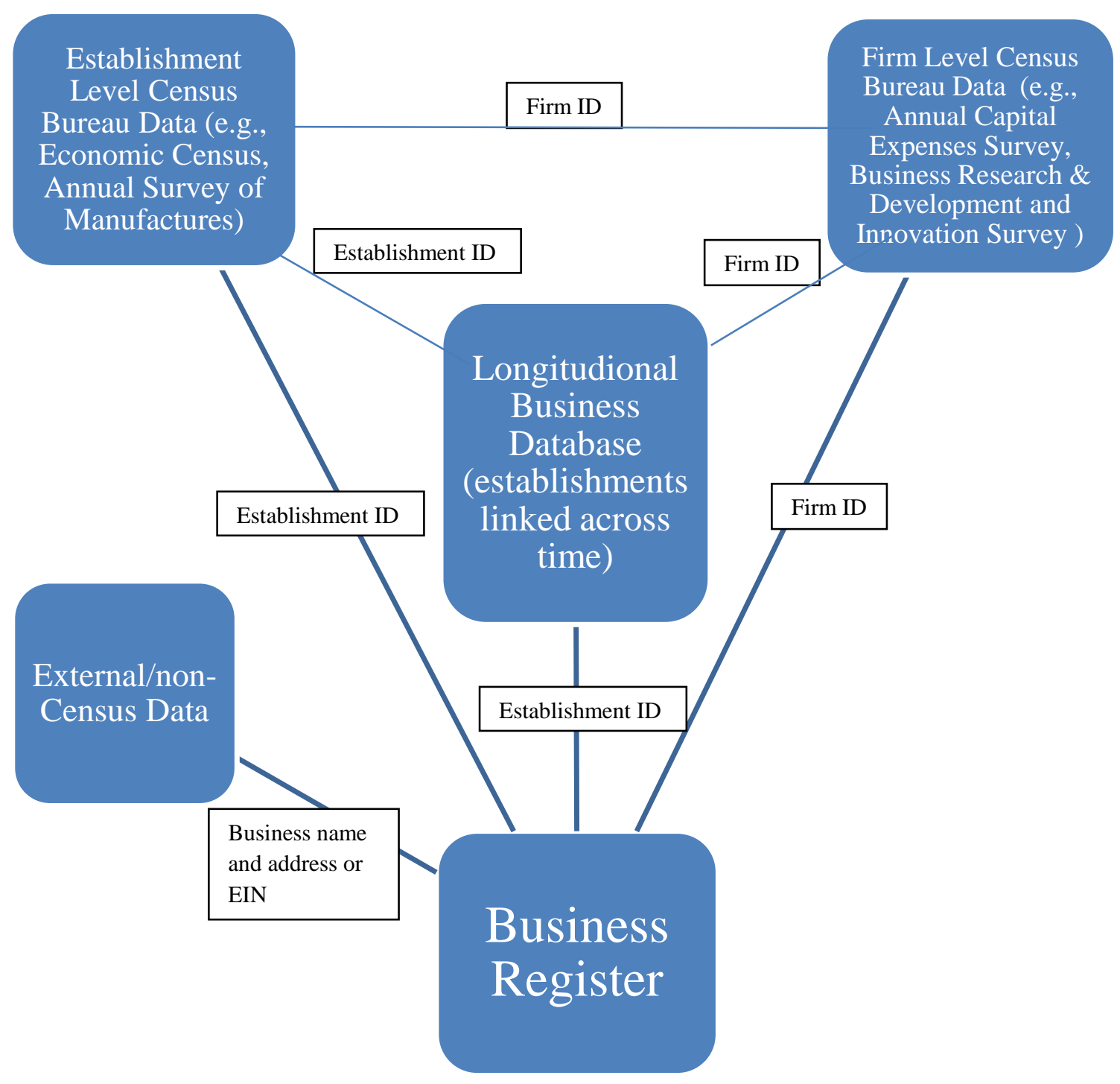




\section{Conclusion}

The primary purpose of the BR is to provide a sampling frame for economic censuses and surveys. It provides resources for the Census Bureau’s economic programs for sample selection, maintenance, and survey operations. For external researchers and CES staff, the BR and LBD serve as the backbone of most economic research by allowing linkages of business establishments and firms across data sources including the Economic Census, business surveys and Longitudinal Employer-Household Dynamics data. Linkage files exist for external data sources such as Compustat and data from other institutions (e.g. USPTO’s patent data, EPA's toxic release inventory and the Kauffman Foundation's Survey). For more information about Census Bureau data available in the

Federal Statistical Research Data Centers, see the Center for Economic Studies’ webpage at https://www.census.gov/ces/rdcresearch/. 


\section{References}

Atalay, Enghin, "Material Prices and Productivity." Journal of the European Economic Association, 2014, 12(s): 575-611. CES 12-11.

Davis, James and Brian Holly. "Regional Analysis Using Census Bureau Microdata at the Center for Economic Studies.” International Regional Science Review, 29(3): 278-296, July 2006.

Davis, Steven, John Haltiwanger, Ron Jarmin, and Javier Miranda. "Volatility and Dispersion in Business Growth Rates: Publicly Traded Versus Privately Held Firm.” NBER Macroeconomics Annual, 2006, 107-180. CES 06-17.

Fairman, Kristen, Lucia Foster, C.J. Krizan, and Ian Rucker. "Analysis of Key Differences in Micro Data: Results from the Business List Comparison Project", American Statistical Association, Proceedings of the Business and Economics Statistics Section, 2008. CES 08-28.

Foster, Lucia, John Haltiwanger and Chad Syverson. "Reallocation, Firm Turnover and Efficiency: Selection on Productivity or Profitability,” American Economic Review, March 2008, 394-425.

Garicano, Luis and Thomas Hubbard. "Managerial Leverage is Limited by the Extent of the Market Hierarchies, Specialization, and the Utilization of Lawyers' Human Capital. Journal of Law and Economics. 50(1), 2007. CES 07-01.

Haltiwanger, John, Ron S. Jarmin, Robert Kulick, and Javier Miranda. High Growth Young Firms: Contribution to Job Growth, Revenue Growth and Productivity. Workshop on Methods and Applications for Dynamic Stochastic General Equilibrium Models. The NBER Reporter 2014, 4. http://www.nber.org/reporter/2014number4/conferences.html, 2014

Hsieh, Chang-Tai and Peter Klenow. "Misallocation and Manufacturing TFP in China and India." Quarterly Journal of Economics, November 2009. 124(4): 1403-1448. CES 09-04.

Jarmin, Ron and Javier Miranda. “The Longitudinal Business Database.” CES 02-17.

McElheran, Kristina. "Delegation in Multi-Establishment Firms: Adaptation vs. Coordination in I.T. Purchasing Authority." Journal of Economics and Management Strategy, Spring 2014. Harvard Business School Working Paper, July 2012.

Natarajan Balasubramanian \& Jagadeesh Sivadasan (2008), "What Happens When Firms Patent? New Evidence from U.S. Economic Census Data," (forthcoming), Review of Economics and Statistics. 
Salyers, Eddie. “Overview of the U.S. Census Bureau’s Business Register Profiling Operations." $21^{\text {st }}$ Meeting of the Wiesbaden Group on Business Registers-International Roundtable on Business Survey Frames. Paris, France. November 24-27, 2008.

Shadbegian, Ronald and Waybe Gray. "Assessing Multi-Dimensional Performance: Environmental and Economic Outcomes.” Journal of Productivity Analysis 26, 2006: 213-234. CES 05-03.

Tolbert, Charles, Carson Mencken, Lynn Riggs, and Jing Li. "Restructuring of the Financial Industry: The Disappearance of Locally Owned Traditional Financial Services in Rural America.” Rural Sociology, 79(3), 2014.

Ufuk Akcigit, William R. Kerr, "Growth through Heterogeneous Innovations" NBER Working paper 16443, February, 2012. 


\section{Appendix - Example Forms}

Census Bureau Form NC-99001 Report of Organization

IRS Form 1065 U.S. Return of Partnership Income

IRS Form 1120 U.S. Corporation Income Tax Return

IRS Form 851 Affiliations Schedule

IRS Form 941 Employer’s Quarterly Federal Tax Return

IRS Form 943 Employer’s Annual Federal Tax Return for Agricultural Employees

IRS Form 944 Employer’s Annual Federal Tax Return

IRS Form 990 Return of Organization Exempt From Income Tax

IRS Form SS-4 Application for Employer Identification Number 
Need help or have questions about filling out this form?

Visit https://econhelp.census.gov/cosasm

$$
\text { - OR - }
$$

Write to the address below. Include your 11-digit Census File Number (CFN) printed in the mailing address.

Mail your completed form to:

\section{U.S. CENSUS BUREAU}

1201 East 10th Street

Jeffersonville, IN 47132-0001

\section{NC-99001}

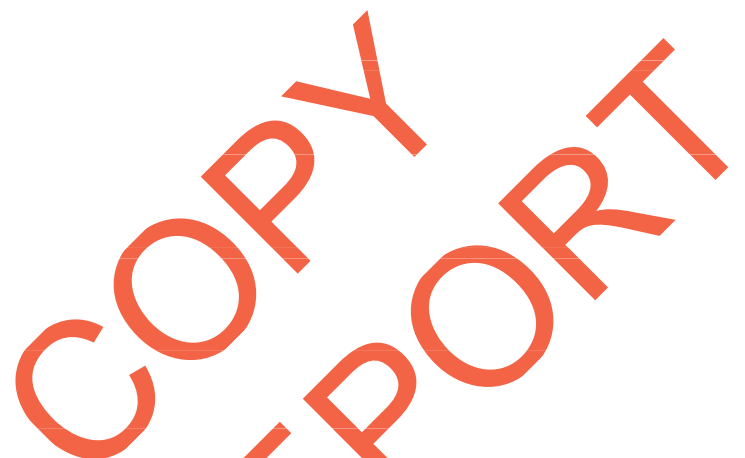

YOUR RESPONSE IS REQUIRED BY LAW. Title 13, United States Code, requires businesses and other organizations that receive this questionnaire to answer the questions and return the report to the U.S. Census Bureau. By the same law, YOUR CENSUS REPORT IS CONFIDENTIAL. It may be seen only by persons sworn to uphold the confidentiality of Census Bureau information and may be used only for statistical purposes. Further, copies retained in respondents' files are immune from legal process.

The purpose of this form is to obtain an accurate and up-to-date list of your establishments, i.e., separate business locations that were in operation or new plant(s) under construction during part or ali of 2014. This list should include establishments of your company and each of its subsidiaries. To make it easier for you to complete this report, we have prelisted information in (5A that you have previously provided to the U.S. Census Bureau. Please list all other eștablishments of your organization on (5B. Do not duplicate establishments already prelisted in 5 A. Be sure to include items (1) through 4 when returning you completed report form. Before completing this form, please read the enclosed definitions and instructions.

- Use blue or black ballpoint pen.

- Do not use pencil or felt-tip pen.

- Do not put slashes through 0 or 7.

- Please center numbers in their respective boxes. Place an " $X$ " inside the box.

\section{Examples:}

1 COMPANY OWNERSHIP OR CONTROL

A. DOMESTIC OWNERSHIP OR CONTROL

1. Does another domestic company hold more than 50 percent of the voting stock of your company or have the Dower to control the management and policies of your company? 0008 $\square$ Yes - Enter the following information of the owning or $\quad 0009 \square$ No - Go to line B
controlling company

0080 Name of owning or controlling company $\quad{ }^{0081}$ Employer Identification Number (EIN) of owning or controlling company (9 digits) $\longrightarrow$

0082 Home office address (Number and street)

0083 City, town, village, etc. 0084 State 0085 ZIP Code

2. What percent of voting stock was held by the owning or controlling company? (Mark " $X$ " only ONE box.) $0027 \square$ Less than $50 \% \quad 0028 \quad \square \quad 50 \% \quad 0029 \quad \square \quad$ More than $50 \%$ 


\section{COMPANY OWNERSHIP OR CONTROL - Continued}

B. FOREIGN OWNERSHIP OR CONTROL

Does a foreign entity (company, individual, government, etc.) own directly or indirectly 10 percent or more of the voting stock or other equity rights of your company?

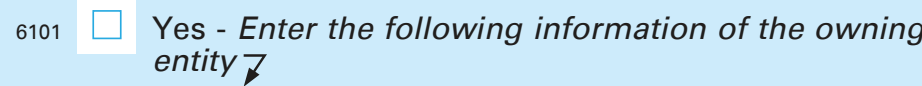

6103 Name of foreign beneficial owner

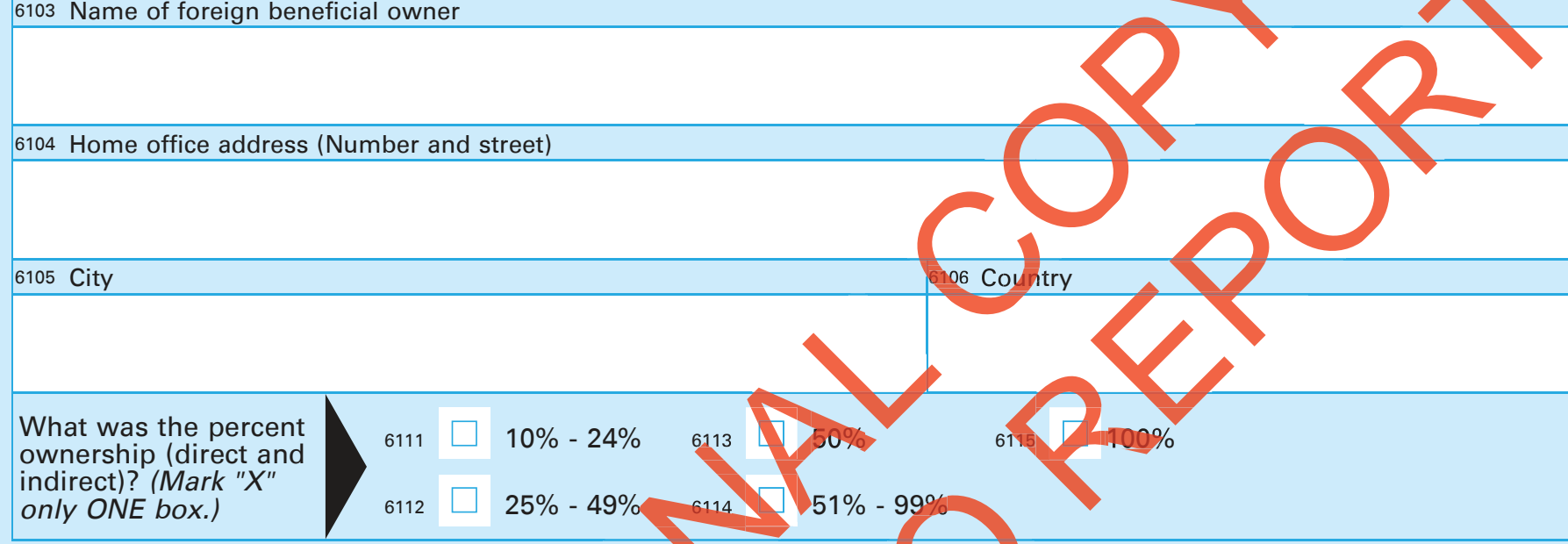

C. FOREIGN AFFILIATES

Does this company alone, or with its domestic affiliates, own 10 percent or more of the voting stock of an incorporated foreign business enterprise or an equivalent interest in an unincorporated business enterprise, including ownership of real estate?

$6126 \square$ Yes
$6127 \square$ No

2 RESEARCH AND DEVELOPMEN

A. Did your company pelform or fund research and development (R\&D) in 2014?
$6129 \square$ Yes - Go to line $B$
$6130 \square$ No - Go to 3 on the inext page

B. What were your company sorldwide expenses for research and development (R\&D) in 2014?

Less than $\$ 3$ million

$6133 \square \$ 3$ million or more 


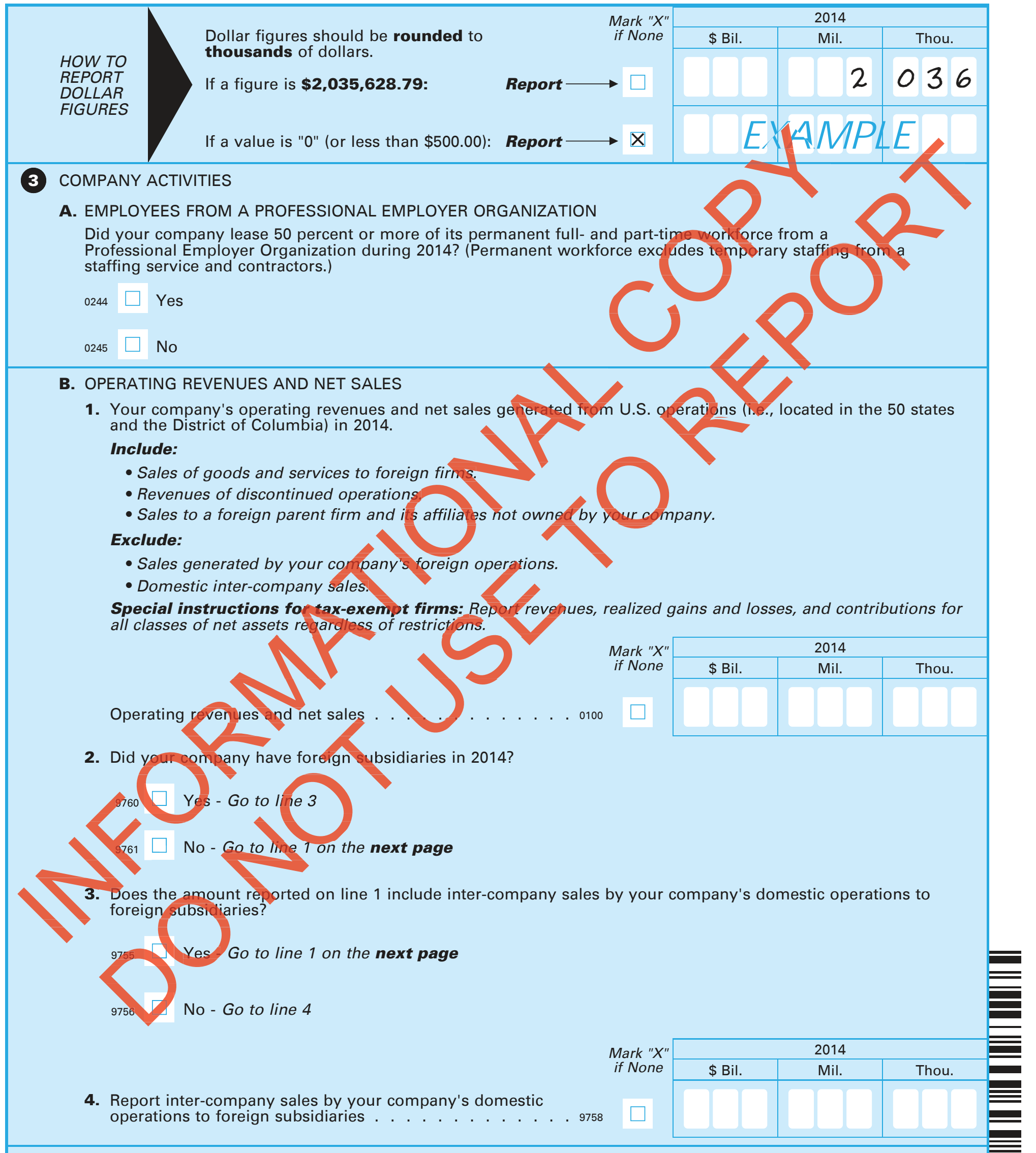




\section{COMPANY ACTIVITIES - Continued}

\section{ROYALTIES AND LICENSE FEES FOR THE USE OF INTELLECTUAL PROPERTY}

1. Did your company's U.S. operations earn revenue in 2014 from royalties or license fees for rights to use intellectual property?

\section{Include:}

- Revenues from royalties and license fees for intellectual property owned by your domestic company's domestic operations (i.e., located in the 50 states and the District of Columbia).

- Royalties and license fees paid to your company's domestic operations by foreign subsidiaries.

\section{Exclude:}

- Sales involving the transfer of ownership rights.

- Sales of and products sold with end-use licenses.

- Franchise fees.
9701
Yes - Go to line 2
$9702 \square$ No - Go to line 1 on the next page

2. Revenues from royalties and license fees in 2014 for rights to use intellectual property . . . . . . . . . . 9703 3. Revenues from your company's U.S. operations, aS
reported in line 2, for the following types of royalties
and license fees in 2014:

a. Technological or industrial processes (Include patents, trade secrets, and proprietary technology. Exclude computer software.). . . . . . . . 9704

b. Entertainment, artistic, educational, and literary original works (Include royalties and license fees for rights to perform, broadcast, reproduce, and sell copyrighted materials and othe intellectual property such as films, television and radio programs, written works, and musical and other artistic works. Exclude computer software.).

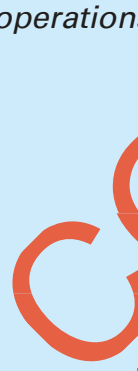

Software - Rights to reproduce, distribute, or use software protected by copyright and owned or controlled by the licensor (Exclude sales of software sold with end-use licenses, as well as custom software and programming services.) ........... . . . . 9706

d. Other revenues from rovalties and license fees for rights to use intellectual property - Specify 7

9752
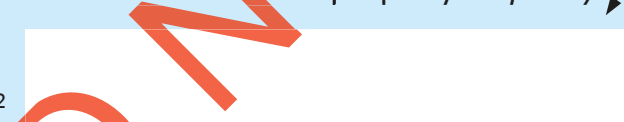

e. TO AL revenues from royalties and license fees in 2014 for rights to use intellectual property (Sum of lines $3 a$
through $3 d$ should equal line 2.) . . . . . . . . . . . 9708

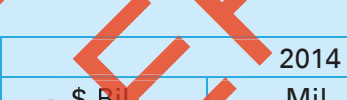

Mil.
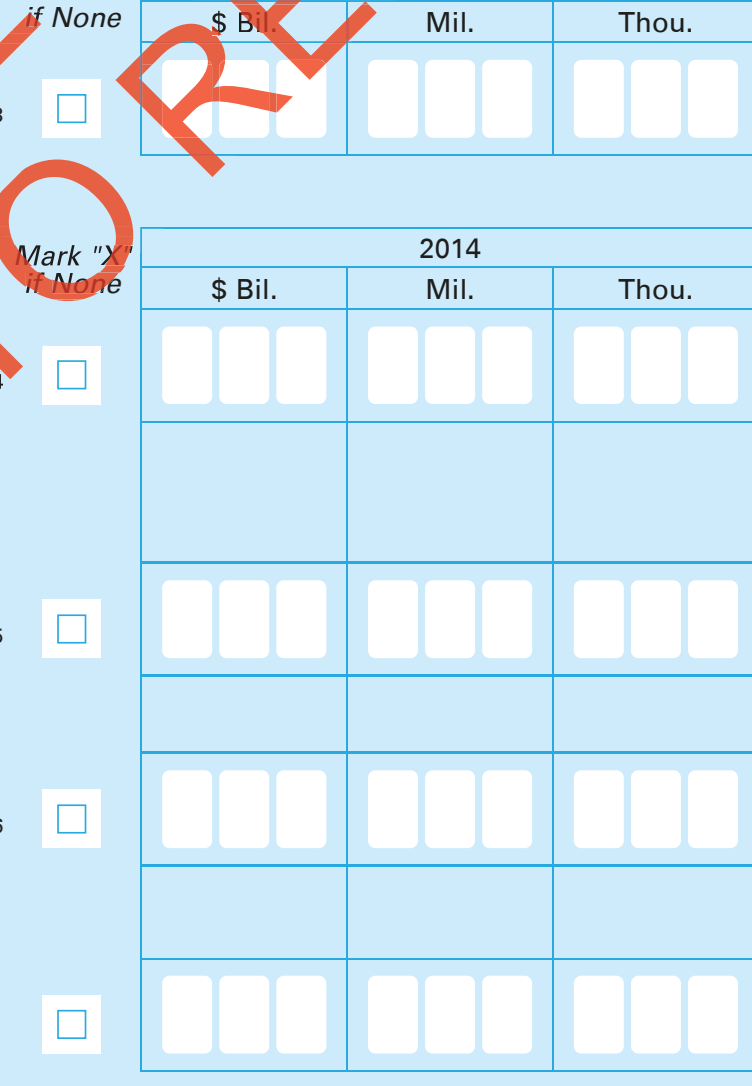

through $3 d$ should equal line 2.) . . . . . . . . . . . . 9708 


\section{COMPANY ACTIVITIES - Continued}

\section{MANUFACTURING ACTIVITIES - Please respond even if you are not a manufacturer.}

In 2014, did your company do any of the following activities related to manufacturing?

1. Operate manufacturing facilities (such as a factory, plant, or mill) where products are completed or partially produced?

$9709 \quad \square \quad$ Yes - Go to line 2
$9710 \quad \square \quad$ No - Go to line 3

2. Provide contract manufacturing services to other companies incorporating their patents, trade secrets, proprietary technology?

$$
\begin{aligned}
& 9711 \quad \square \quad \text { Yes } \\
& 9712 \quad \square \quad \text { No - Go to line 3 }
\end{aligned}
$$

Estimate the percent of operating revenues and net sales, as reported in 3B, OPERATING REVENUES AND NET SALES, from contract manufacturing services.

$$
\begin{aligned}
& 9713 \quad \square \quad \text { Less than 25\% } \\
& 9714 \quad \square \quad 25 \%-49 \% \\
& 9715 \quad \square \quad 50 \%-74 \% \\
& 9716 \quad \square \quad 75 \%-99 \% \\
& 9717 \quad \square \quad 100 \%
\end{aligned}
$$
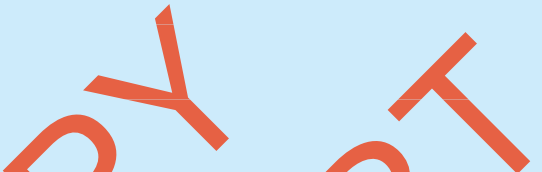

3. Purchase contract manufacturing services from othe companies or foreign subsidiaries of your company incorporating your company's patents, trade secréts, or proprietary technology?

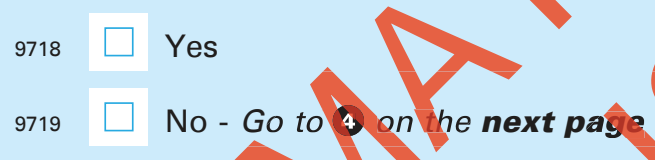

a. Use 3rd party contract manufacturing services inside the United States (i.e., located in the 50 states and the District of Columbia)?

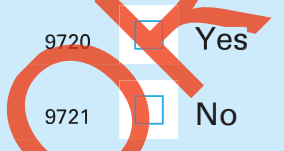

b. Use 3rd party contract manufacturing services outside the United States (i.e., located outside the 50 states and the District of Columbia)?
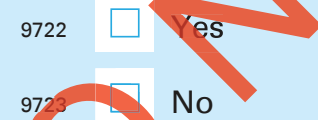

c. Use your company's foreign subsidiaries' or affiliates' contract manufacturing services at locations outside the United States (i.e., located outside the 50 states and the District of Columbia)?

d. Estimate the percent of the cost of sales from expenses for contract manufacturing services.
$9726 \square$ Less than $25 \%$
$9727 \square 25 \%-49 \%$
$9728 \square 50 \%-74 \%$
$9729 \square 75 \%-99 \%$
$9730 \quad \square \quad 100 \%$ 


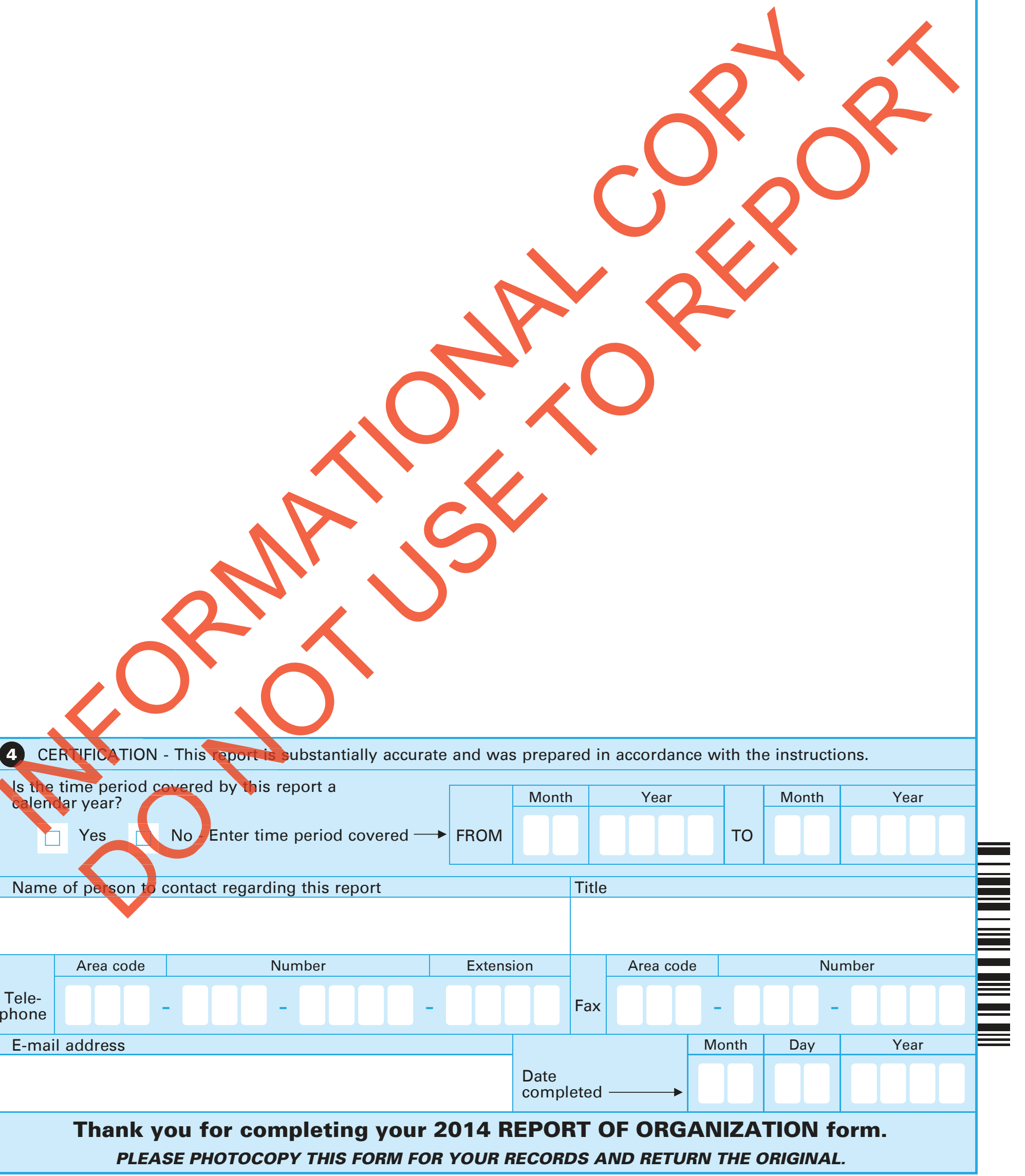


FORM NC-99001

(11-20-2014)
U.S. DEPARTMENT OF COMMERCE Economics and Statistics Administration

\section{REPORT OF ORGANIZATION}

\section{Refer to this}

CENSUS FILE NUMBER

in any correspondence

pertaining to this report

5 A. PRE-IDENTIFIED LOCATIONS OF OPERATION

We have listed establishments of your company based on Census records. Please update this list as follows:

Column (a) - Correct any errors or omissions in the information. The establishments are listed in the following sequence: Employer Identification Number (EIN), major activity, and geographic location.

Company Establishments and Subsidiaries (Add store or plant number, if any, and correct any errors or omissions.)

(a)

(b)

\begin{tabular}{l|l}
\hline Line No. EIN \\
\hline \multicolumn{2}{|l}{ Major activity }
\end{tabular}

Name

Secondary name

First quarter payroll (January-March 2014)

Physical location (Number and street)

City, town, village, etc. State ZIP Code

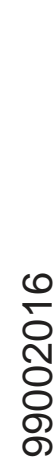

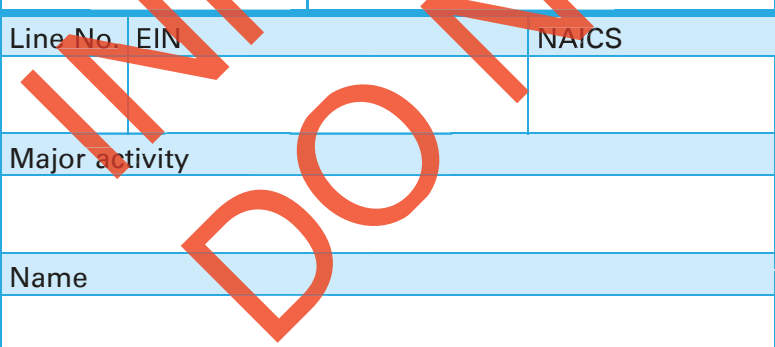

Secondary name

Store/Plant No.

Physical location (Number and street)

City, town, village, etc.

State ZIP Code

Column (b) - Report the number of employees and payroll for full- and part-time em ployees working at each establishment whose payroll was reported on your Internal Revenue Service Form 941, Employer's Quarterly Federal Tax Return. Include part-year operations. Do not combine data for estab/ishments. If book figures are not available for employment and payroll for each establishment, please provide your best estimates.

Column (c) - Report operational status of each establishment at the end of 2014.
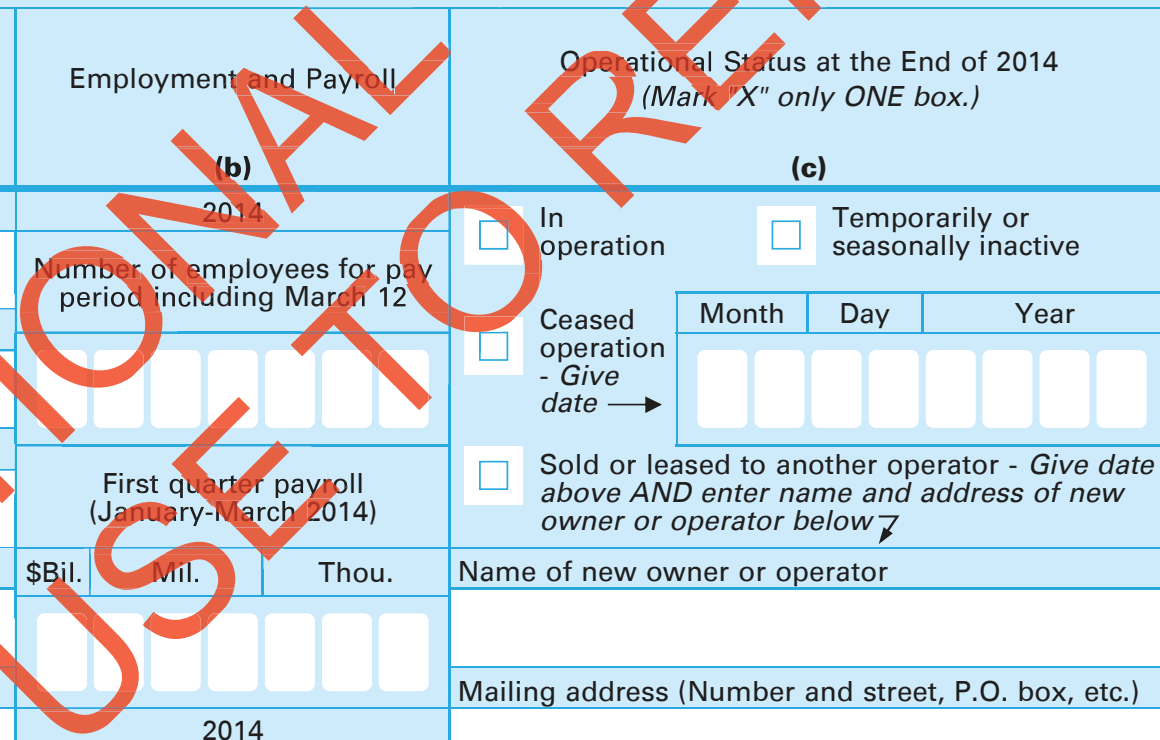

Mailing address (Number and street, P.O. box, etc.) above AND enter name and address of new owner or operator below 7

Name of new owner or operator

Annual payroll

\$Bil. Mil. $\quad$ Thou.

\begin{tabular}{|l|l|l} 
City, town, village, etc. & State & ZIP Code
\end{tabular}

Other -

Specify $\longrightarrow$

In $\quad \square$ Temporarily or

operation $\quad \square$ seasonally inactive

Number of employees for pay period including March 12

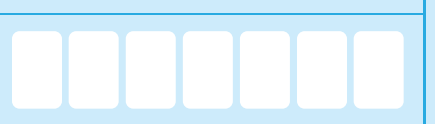

First quarter payroll (January-March 2014)

\begin{tabular}{l|l|l} 
\$Bil. Mil. & Thou.
\end{tabular}

Name of new owner or operator

\begin{tabular}{ll|l|l}
\cline { 2 - 3 } Ceased & Month & Day & Year \\
\cline { 2 - 3 }
\end{tabular}
operation - Give date $\longrightarrow$

Sold or leased to another operator - Give date above AND enter name and address of new owner or operator below 7

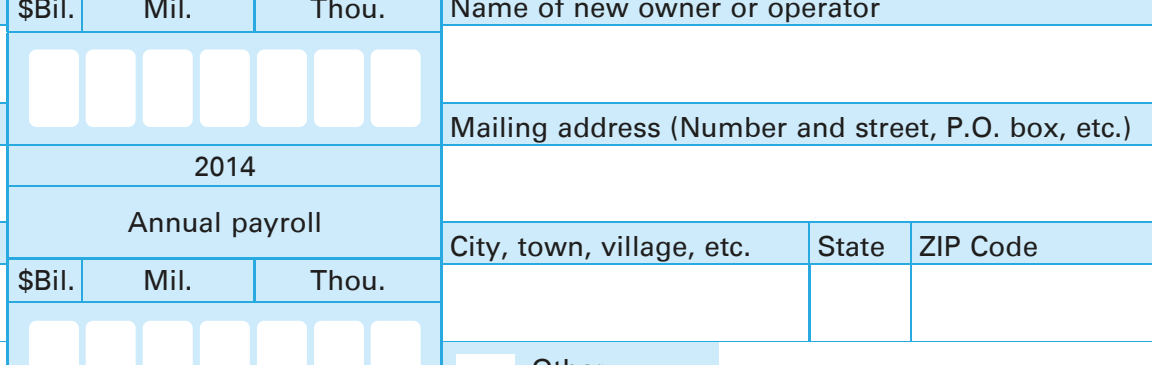

Other Specify 
Form NC-99001 (11-20-2014)

\section{A. PRE-IDENTIFIED LOCATIONS OF OPERATION - Continued}

(a) Company Establishments and Subsidiaries

Line No. EIN

NAICS

Major activity

Name

Secondary name Store/Plant No.

Physical location (Number and street)

\begin{tabular}{l|l|l} 
City, town, village, etc. & State & ZIP Code
\end{tabular}

\begin{tabular}{l|l|l}
\hline Line No. EIN & NAICS
\end{tabular}

Major activity

\section{Name}

\section{Secondary name}

Physical location (Number and ștreet

\section{City, town, village, etc. State ZIP Code}

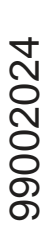

Name

\section{Secondary name}

Physical location (Number and street)

City, town, village, etc.

State ZIP Code
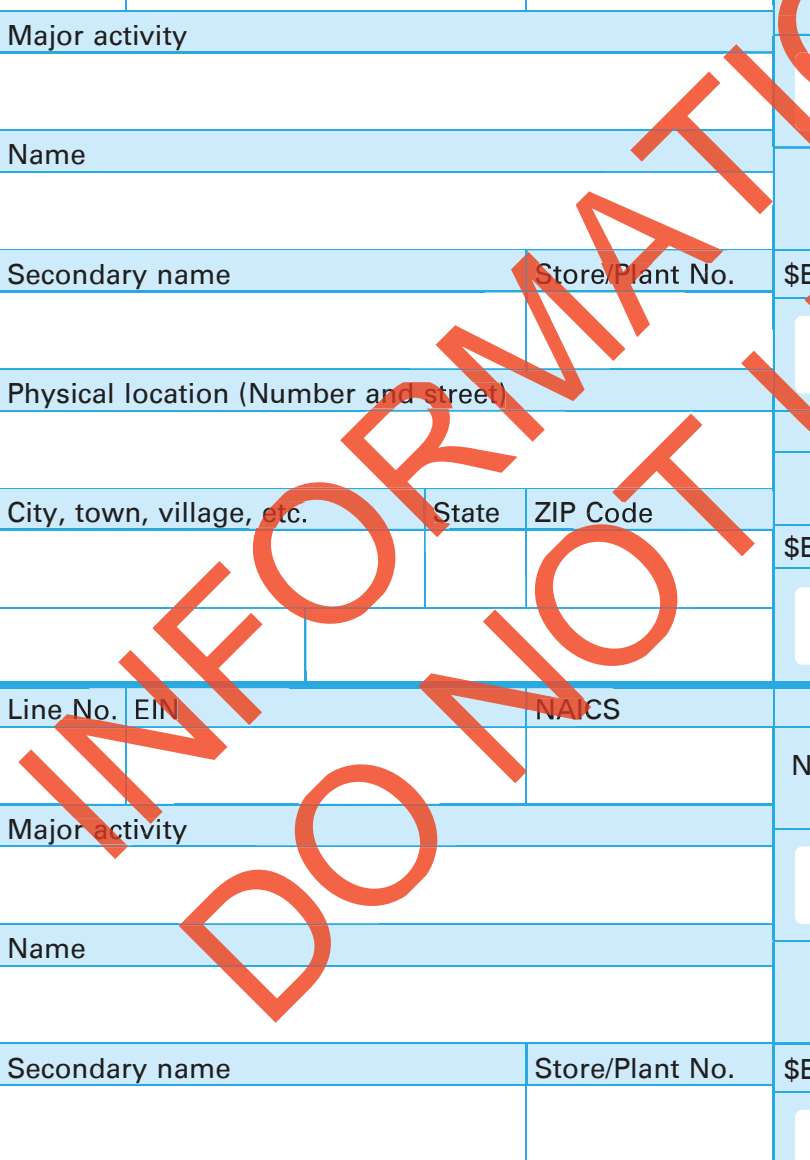

(b) Employment and Payroll

2014

Number of employees for pay period including March 12

First quarter payroll (January-March 2014)

\begin{tabular}{l|l|l} 
\$Bil. Mil. & Thou.
\end{tabular}

2014

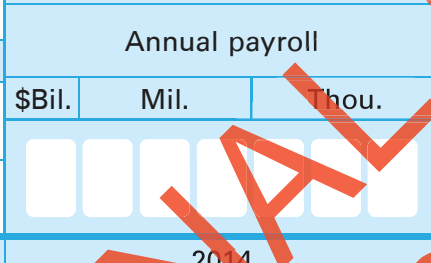

Number of employees for pay period including March 12

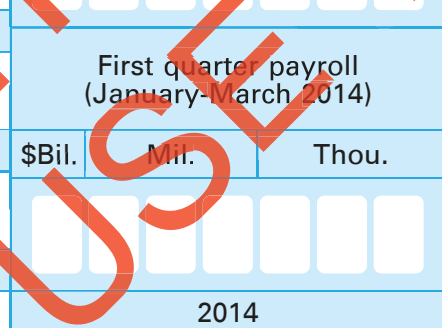

Annual payroll

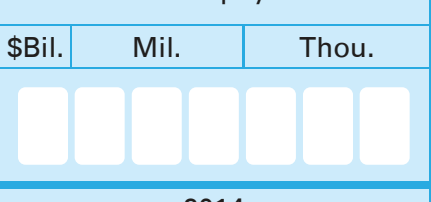

Number of employees for pay period including March 12

(c) Operational Status at the End of 2014

$\square \begin{aligned} & \text { In } \\ & \text { operation } \quad \square \quad \begin{array}{l}\text { Temporarily or } \\ \text { seasonally inactive }\end{array}\end{aligned}$

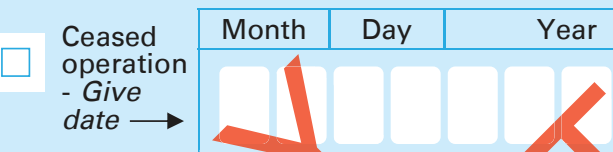

$\square$ Sold or leased to another operator - Give date above AND enter name and address of new owner or operator below7

Name of new owher or operator

Mailing address (Number and strect, P.O. box, etc.)

City, town, village, etc. State ZIP Code

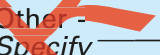

Specify $\longrightarrow$

In $\square$ Temporarily or

operation

\begin{tabular}{l|l|l|l} 
Ceased & Month & Day & Year \\
\cline { 2 - 3 }
\end{tabular}

operation

- Give

date $\longrightarrow$

Sold or leased to another operator - Give date above AND enter name and address of new owner or operator below 7

Name of new owner or operator

Mailing address (Number and street, P.O. box, etc.)

\begin{tabular}{l|l|l} 
City, town, village, etc. & State & ZIP Code
\end{tabular}

Other -

Specify

In Temporarily or

operation $\quad \square$ seasonally inactive

\begin{tabular}{ll|l|l}
\cline { 2 - 3 } Ceased & Month & Day & Year \\
\hline
\end{tabular}

$\square$ operation

- Give

date $\longrightarrow$

First quarter payroll

(January-March 2014)

\begin{tabular}{|c|c|c|}
\hline \$Bil. & Mil. & Thou. \\
\hline &
\end{tabular}

Sold or leased to another operator - Give date above AND enter name and address of new owner or operator below 7

Name of new owner or operator

Mailing address (Number and street, P.O. box, etc.) 2014

Annual payroll

\begin{tabular}{l|l|l}
\hline \$Bil. Mil. & Thou.
\end{tabular}


FORM NC-99001

(11-20-2014)
U.S. DEPARTMENT OF COMMERCE Economics and Statistics Administration
U.S. CENSUS BUREAU
Refer to this

CENSUS FILE NUMBER

in any correspondence

pertaining to this report

\section{B. ADDITIONAL LOCATIONS OF OPERATION}

Column (a) - List separately any establishments of your company and its subsidiaries that were not included on the PRE-IDENTIFIED LOCATIONS OF OPERATION. If your company operates at locations for which you have received separate report forms, do not list them, instead complete those forms. For acquired establishments that you list, complete column (c2).

Column (b) - Report the number of employees and payroll for full- and part-time employees working at each establishment whose payroll was reported on your Internal Revenue Service Forms 941, Employer's Quarterly Federal Tax Return. Include part-year operations. Do not combine data for establishments. If book figures are not available for employment and payroll for each establishment, please provide your best estimates.

Column (c1) - Enter the code from the MAJOR ACTIVITY CODES list that best describes the activity of each establishment and specify the principal products or services.

Column (c2) - Complete for acquired establishments

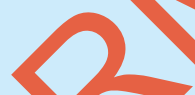

\section{IMPORTANT - DO NOT DUPLICATE ESTABLISHMENTS PRELISTED IN GA.}

Company Establishments and Subsidiarie (Enter Employen dentification Number (EIN), establishment name, your store or plant number, if any, address of physical location, including ZIP Code.)

\section{(a)}

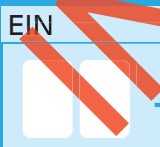

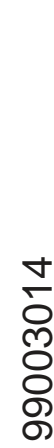$$
\text { Sen }
$$

Secondary name

Physical location (Number and street)
Employment and Payroll

(b)

\author{
MAJOR ACTIVITY CODES FOR COLUMN (c1) \\ 01 - Agricultural production \\ 02 - Agricultural services \\ 03 - Minerals extraction/ore processing \\ 04 - Mining services/oit and gas field services \\ 05 - Utilities \\ 06 - Construction \\ 07 - Manufacturing \\ 08 - Merchant wholesäler \\ 09 - Commission merchant/brokêr/agent/electronic marketer \\ (business to business) \\ 10. Manufacturers' sales branch/manufacturers' sales office \\ 11 - Retail \\ 12. Transportation/Rublic Warehousing \\ 3 - Information services/publishing/telecommunications \\ 14.- Finance/insurance \\ 15 - Real estate/renting/leasing \\ 16 - Professional/scientific/technical service \\ 17. Waste management/remediation service/administrative/ \\ 18 - Educational service \\ 19 - Health care \\ 20 - Social assistance \\ 21. Arts/entertainment/recreation \\ 22 - Accommodation/food service \\ 23 - Corporate/subsidiary/regional/managing office \\ 24 - Other - Specify major activity along with principal products \\ or services in column (c1) below.
}

\begin{tabular}{|c|c|c|c|}
\hline \multicolumn{4}{|l|}{ Name } \\
\hline \multicolumn{3}{|c|}{ Secondary name } & Store/Plant No. \\
\hline \multicolumn{4}{|c|}{ Physical location (Number and street) } \\
\hline \multicolumn{2}{|c|}{ City, town, village, etc. } & State & ZIP Code \\
\hline \multirow{2}{*}{$\begin{array}{l}\text { Date } \\
\text { establishment } \\
\text { opened or is } \\
\text { expected to } \\
\text { open }\end{array}$} & Month & Day & Year \\
\hline & & & \\
\hline
\end{tabular}

Major Activity in 2014

(Enter code from the MAJOR ACTIVITY CODES list and specify the principal products or services.)

(c1)

\begin{tabular}{|l|l|l}
\hline $\begin{array}{c}\text { Number of employees for pay } \\
\text { period including March 12 }\end{array}$ & Code & Specify \\
\hline & & \\
\hline (c2) Former Owner or Operator
\end{tabular}

First quarter payroll (January-March 2014)

\begin{tabular}{l|l|l} 
\$Bil. Mil. & Thou.
\end{tabular}

Name of former owner or operator

Mailing address (Number and street, P.O. Box, etc.)

City, town, village, etc. $\quad$ State ZIP Code

\begin{tabular}{c|c|c} 
& \multicolumn{2}{c}{2014} \\
\hline \multicolumn{3}{|c|}{ Annual payroll } \\
\hline \$Bil. & Mil. & Thou. \\
\hline & & \\
\hline
\end{tabular}


Form NC-99001 (11-20-2014)

(5) B. ADDITIONAL LOCATIONS OF OPERATION - Continued

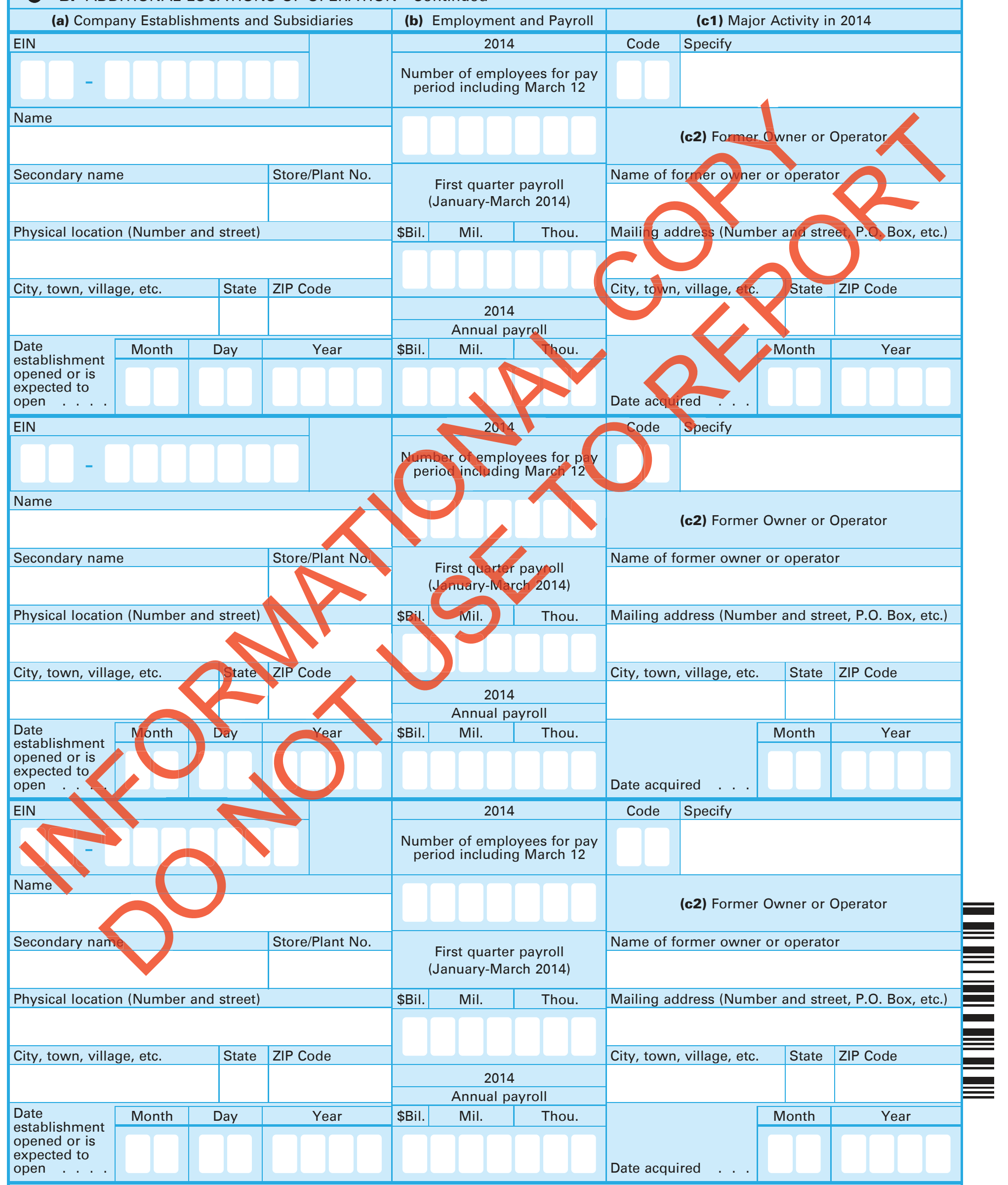


rom 1065

Department of the Treasury Internal Revenue Service

A Principal business activity

B Principal product or service

C Business code number
U.S. Return of Partnership Income

, 2014, ending

For calendar year 2014, or tax year beginning

Information about Form 1065 and its separate instructions is at www.irs.gov/form 1065.

Typ

\begin{tabular}{|l|l|} 
& Name of partnership \\
\cline { 2 - 3 } & Number, street, and room or suite no. If a P.O. box, see the instructions. \\
\cline { 2 - 3 } & City or town, state or province, country, and ZIP or foreign postal code \\
\end{tabular}
G Check applicable boxes:
(1) $\square$ Initial return (2) $\square$ Final return
(3) $\square$ Name change
(4) $\square$ Address change
(5) $\square$ Amended return
(6) $\square$ Technical termination - also check (1) or (2)
H Check accounting method:
I Number of Schedules K-1. Att
(2) $\square$ Accrual
(3) $\square$ Other (specify)
I Number of Schedules K-1. Attach one for each person who was a partner at any time during the tax year
J Check if Schedules $\mathrm{C}$ and $\mathrm{M}-3$ are attached

Caution. Include only trade or business income and expenses on lines 1a through 22 below. See the instructions for more information.

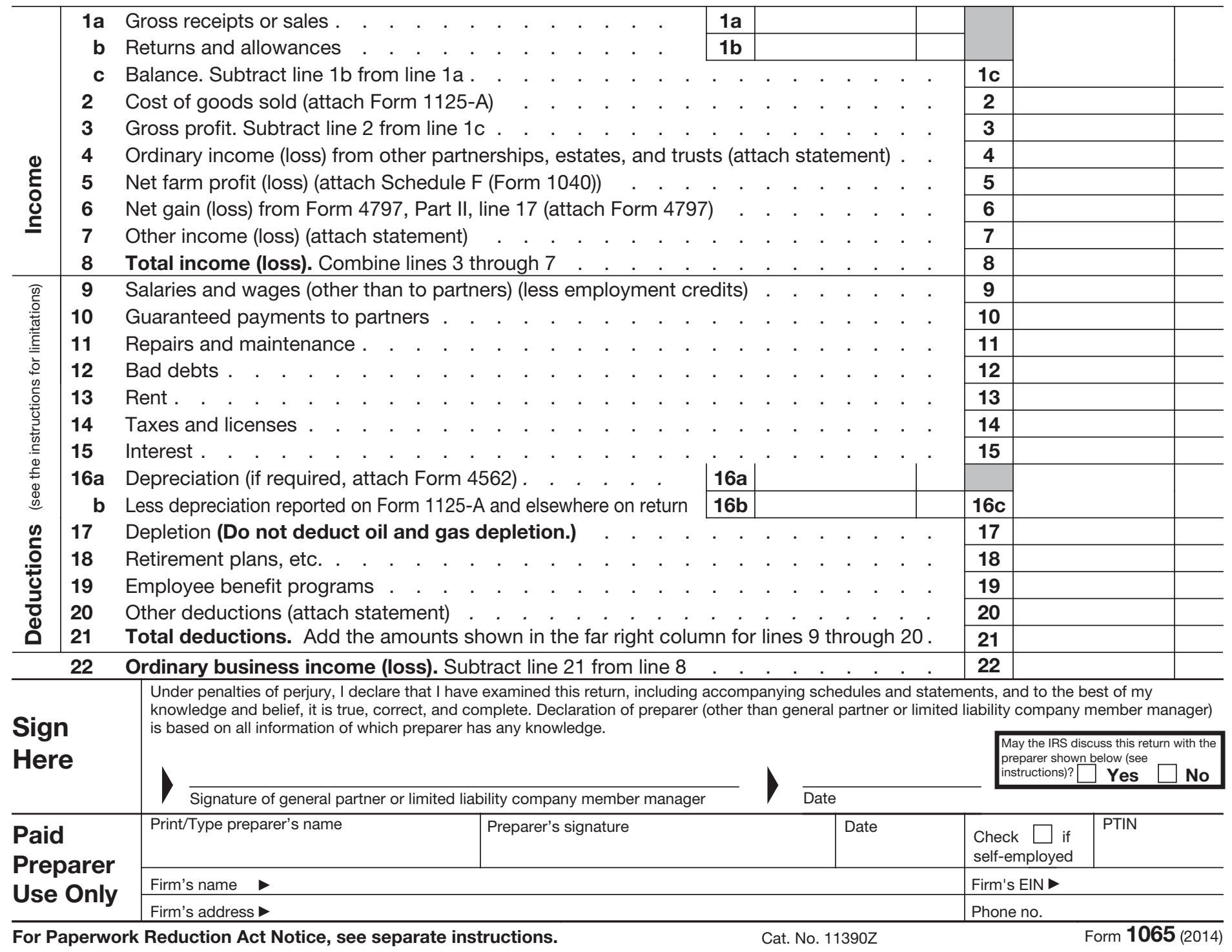


Schedule B $\quad$ Other Information

1 What type of entity is filing this return? Check the applicable box:

a $\square$ Domestic general partnership

b $\square$ Domestic limited partnership

c $\square$ Domestic limited liability company

d $\square$ Domestic limited liability partnership

e $\square$ Foreign partnership

f $\square$ Other

2 At any time during the tax year, was any partner in the partnership a disregarded entity, a partnership (including an entity treated as a partnership), a trust, an S corporation, an estate (other than an estate of a deceased partner), or a nominee or similar person?

3 At the end of the tax year:

a Did any foreign or domestic corporation, partnership (including any entity treated as a partnership), trust, or taxexempt organization, or any foreign government own, directly or indirectly, an interest of $50 \%$ or more in the profit, loss, or capital of the partnership? For rules of constructive ownership, see instructions. If "Yes," attach Schedule B-1, Information on Partners Owning 50\% or More of the Partnership .

b Did any individual or estate own, directly or indirectly, an interest of $50 \%$ or more in the profit, loss, or capital of the partnership? For rules of constructive ownership, see instructions. If "Yes," attach Schedule B-1, Information on Partners Owning 50\% or More of the Partnership

$4 \quad$ At the end of the tax year, did the partnership:

a Own directly $20 \%$ or more, or own, directly or indirectly, $50 \%$ or more of the total voting power of all classes of stock entitled to vote of any foreign or domestic corporation? For rules of constructive ownership, see instructions. If "Yes," complete (i) through (iv) below .

\begin{tabular}{l|l|l|l}
\hline (i) Name of Corporation & $\begin{array}{c}\text { (ii) Employer Identification } \\
\text { Number (if any) }\end{array}$ & $\begin{array}{c}\text { (iii) Country of } \\
\text { Incorporation }\end{array}$ & $\begin{array}{c}\text { (iv) Percentage } \\
\text { Owned in Voting Stock }\end{array}$ \\
\hline & & & \\
\hline \\
\hline
\end{tabular}

b Own directly an interest of $20 \%$ or more, or own, directly or indirectly, an interest of $50 \%$ or more in the profit, loss, or capital in any foreign or domestic partnership (including an entity treated as a partnership) or in the beneficial interest of a trust? For rules of constructive ownership, see instructions. If "Yes," complete (i) through (v) below .

\begin{tabular}{l|l|l|l|l}
\hline (i) Name of Entity & $\begin{array}{c}\text { (ii) Employer } \\
\text { Identification } \\
\text { Number (if any) }\end{array}$ & $\begin{array}{c}\text { (iii) Type of } \\
\text { Entity }\end{array}$ & $\begin{array}{c}\text { (v) Maximum Country of } \\
\text { Organization }\end{array}$ & $\begin{array}{c}\text { Percentage Owned in } \\
\text { Profit, Loss, or Capital }\end{array}$ \\
\hline & & & & \\
\hline & & & & \\
\hline
\end{tabular}

5 Did the partnership file Form 8893, Election of Partnership Level Tax Treatment, or an election statement under section 6231(a)(1)(B)(ii) for partnership-level tax treatment, that is in effect for this tax year? See Form 8893 for more details

6 Does the partnership satisfy all four of the following conditions?

a The partnership's total receipts for the tax year were less than $\$ 250,000$.

b The partnership's total assets at the end of the tax year were less than $\$ 1$ million.

c Schedules K-1 are filed with the return and furnished to the partners on or before the due date (including extensions) for the partnership return.

d The partnership is not filing and is not required to file Schedule M-3

If "Yes," the partnership is not required to complete Schedules L, M-1, and M-2; Item F on page 1 of Form 1065; or Item L on Schedule K-1.

7 Is this partnership a publicly traded partnership as defined in section 469(k)(2)? .

8 During the tax year, did the partnership have any debt that was cancelled, was forgiven, or had the terms modified so as to reduce the principal amount of the debt?

9 Has this partnership filed, or is it required to file, Form 8918, Material Advisor Disclosure Statement, to provide information on any reportable transaction?

10 At any time during calendar year 2014, did the partnership have an interest in or a signature or other authority over a financial account in a foreign country (such as a bank account, securities account, or other financial account)? See the instructions for exceptions and filing requirements for FinCEN Form 114, Report of Foreign Bank and Financial Accounts (FBAR). If "Yes," enter the name of the foreign country. 
11 At any time during the tax year, did the partnership receive a distribution from, or was it the grantor of, or transferor to, a foreign trust? If "Yes," the partnership may have to file Form 3520, Annual Return To Report Transactions With Foreign Trusts and Receipt of Certain Foreign Gifts. See instructions

12a Is the partnership making, or had it previously made (and not revoked), a section 754 election? See instructions for details regarding a section 754 election.

b Did the partnership make for this tax year an optional basis adjustment under section 743(b) or 734(b)? If "Yes," attach a statement showing the computation and allocation of the basis adjustment. See instructions . . . .

c Is the partnership required to adjust the basis of partnership assets under section $743(\mathrm{~b})$ or $734(\mathrm{~b})$ because of a substantial built-in loss (as defined under section 743(d)) or substantial basis reduction (as defined under section 734(d))? If "Yes," attach a statement showing the computation and allocation of the basis adjustment. See instructions

13 Check this box if, during the current or prior tax year, the partnership distributed any property received in a like-kind exchange or contributed such property to another entity (other than disregarded entities wholly owned by the partnership throughout the tax year)

14 At any time during the tax year, did the partnership distribute to any partner a tenancy-in-common or other undivided interest in partnership property? .

15 If the partnership is required to file Form 8858, Information Return of U.S. Persons With Respect To Foreign Disregarded Entities, enter the number of Forms 8858 attached. See instructions

16 Does the partnership have any foreign partners? If "Yes," enter the number of Forms 8805, Foreign Partner's Information Statement of Section 1446 Withholding Tax, filed for this partnership.

17 Enter the number of Forms 8865, Return of U.S. Persons With Respect to Certain Foreign Partnerships, attached to this return.

18a Did you make any payments in 2014 that would require you to file Form(s) 1099 ? See instructions $\quad . \quad$. . . . .

b If "Yes," did you or will you file required Form(s) 1099? .

19 Enter the number of Form(s) 5471, Information Return of U.S. Persons With Respect To Certain Foreign Corporations, attached to this return.

20 Enter the number of partners that are foreign governments under section 892.

Designation of Tax Matters Partner (see instructions)

Enter below the general partner or member-manager designated as the tax matters partner (TMP) for the tax year of this return:

\begin{tabular}{|c|c|}
\hline $\begin{array}{l}\text { Name of } \\
\text { designated } \\
\text { TMP }\end{array}$ & $\begin{array}{l}\text { Identifying } \\
\text { number of TMP }\end{array}$ \\
\hline $\begin{array}{l}\text { If the TMP is an } \\
\text { entity, name } \\
\text { of TMP representative }\end{array}$ & $\begin{array}{l}\text { Phone number } \\
\text { of TMP }\end{array}$ \\
\hline
\end{tabular}


1 Ordinary business income (loss) (page 1, line 22)

2 Net rental real estate income (loss) (attach Form 8825)

3a Other gross rental income (loss)

b Expenses from other rental activities (attach statement)

c Other net rental income (loss). Subtract line 3b from line 3a

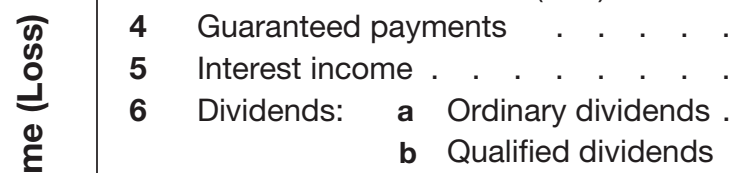

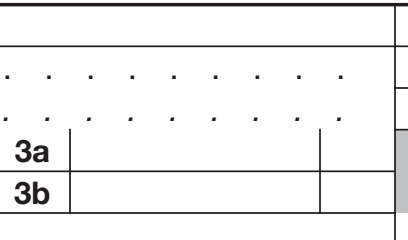

7 Royalties.

b Qualified dividends

8 Net short-term capital gain (loss) (attach Schedule D (Form 1065))

9a Net long-term capital gain (loss) (attach Schedule D (Form 1065))

b Collectibles (28\%) gain (loss)

c Unrecaptured section 1250 gain (attach statement)

10 Net section 1231 gain (loss) (attach Form 4797)

11 Other income (loss) (see instructions) Type

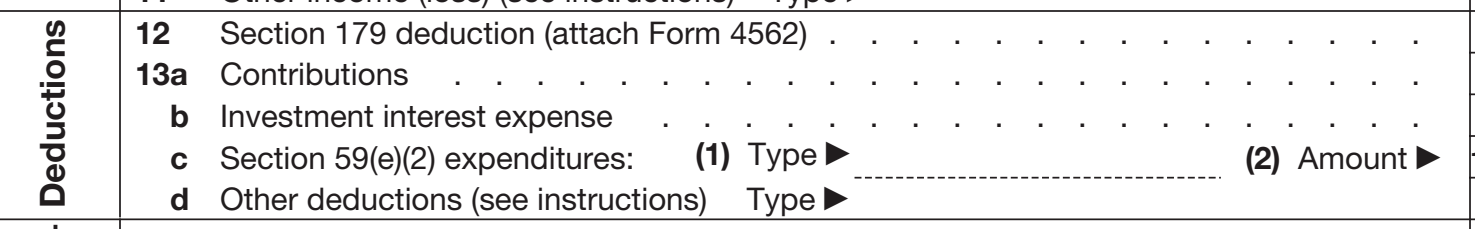

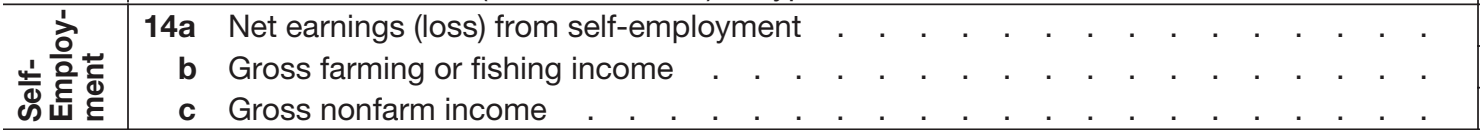

15a Low-income housing credit (section 42(j)(5))

b Low-income housing credit (other)

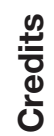

c Qualified rehabilitation expenditures (rental real estate) (attach Form 3468, if applicable)

d Other rental real estate credits (see instructions)

e Other rental credits (see instructions)

f Other credits (see instructions)

16a Name of country or U.S. possession

b Gross income from all sources.

c Gross income sourced at partner level

Foreign gross income sourced at partnership level

d Passive category e General category

Type Type

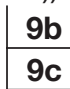

\begin{tabular}{|l|l|l|l}
\hline \multicolumn{2}{|c|}{ Total amou } \\
\hline 1 & \\
\hline 2 & \\
\hline
\end{tabular}

6b

$9 b$

9c

\begin{tabular}{|c|c|}
\hline $3 c$ & \\
\hline 4 & \\
\hline 5 & \\
\hline $6 a$ & \\
\hline & \\
\hline
\end{tabular}

7

8

Deductions allocated and apportioned at partner level

g Interest expense h Other

Deductions allocated and apportioned at partnership level to foreign source income

i Passive category j General category

k Other

I Total foreign taxes (check one): $>$ Paid $\square$ Accrued

m Reduction in taxes available for credit (attach statement)

n Other foreign tax information (attach statement)

Post-1986 depreciation adjustment

b Adjusted gain or loss

c Depletion (other than oil and gas)

d Oil, gas, and geothermal properties-gross income

e Oil, gas, and geothermal properties-deductions .

f Other AMT items (attach statement)

18a Tax-exempt interest income.

b Other tax-exempt income

c Nondeductible expenses .

19a Distributions of cash and marketable securities

b Distributions of other property

20a Investment income.

b Investment expenses

c Other items and amounts (attach statement) 


\section{Analysis of Net Income (Loss)}

1 Net income (loss). Combine Schedule K, lines 1 through 11. From the result, subtract the sum of Schedule K, lines 12 through $13 d$, and 161 2 Analysis by

a General partners

b Limited partners

Schedule L Balance Sheets per Books Assets

1 Cash

2a Trade notes and accounts receivable

b Less allowance for bad debts

3 Inventories

4 U.S. government obligations

5 Tax-exempt securities

6 Other current assets (attach statement) .

7a Loans to partners (or persons related to partners)

b Mortgage and real estate loans

8 Other investments (attach statement).

9a Buildings and other depreciable assets

b Less accumulated depreciation

10a Depletable assets

b Less accumulated depletion

and (net of any amortization)

12a Intangible assets (amortizable only)

b Less accumulated amortization

13 Other assets (attach statement)

14 Total assets.

\section{Liabilities and Capital}

15 Accounts payable

16 Mortgages, notes, bonds payable in less than 1 year

17 Other current liabilities (attach statement)

18 All nonrecourse loans

19a Loans from partners (or persons related to partners)

b Mortgages, notes, bonds payable in 1 year or more

20 Other liabilities (attach statement)

21 Partners' capital accounts

22 Total liabilities and capital

\section{Schedule M-1 Reconciliation of Income (Loss) per Books With Income (Loss) per Return}

Note. The partnership may be required to file Schedule M-3 (see instructions).

1 Net income (loss) per books

2 Income included on Schedule K, lines 1, 2, 3c, $5,6 a, 7,8,9 a, 10$, and 11, not recorded on books this year (itemize):

3 Guaranteed payments (other than health insurance)

4 Expenses recorded on books this year not included on Schedule $\mathrm{K}$, lines 1 through 13d, and 16l (itemize):

a Depreciation \$

b Travel and entertainment $\$$

5 Add lines 1 through 4.

\section{Schedule M-2 Analysis of Partners' Capital Accounts}

1 Balance at beginning of year

2 Capital contributed: a Cash

\section{b Property}

3 Net income (loss) per books.

4 Other increases (itemize):

5 Add lines 1 through 4

\begin{tabular}{|l|}
\hline \\
\hline \\
\hline \\
\hline \\
\hline Capital Accounts \\
\hline \\
\hline \\
\hline \\
\hline
\end{tabular}

6 Income recorded on books this year not included on Schedule K, lines 1 through 11 (itemize):

a Tax-exempt interest $\$$

7 Deductions included on Schedule K, lines 1 through 13d, and 16l, not charged against book income this year (itemize):

a Depreciation $\$$

$8 \quad$ Add lines 6 and 7

Income (loss) (Analysis of "Net "' (Loss), line 1). Subtract line 8 from line 5.
6 Distributions: a Cash
b Property
7 Other decreases (itemize):
8 Add lines 6 and 7
9 Balance at end of year. Subtract line 8 from line 5

(d) 
1a Consolidated return (attach Form 851)

b Life/nonlife consolidated return .

2 Personal holding co. (attach Sch. PH) .

3 Personal service corp. (see instructions)

$\square$
$\square$
$\square$
$\square$
$\square$
$\square$

U.S. Corporation Income Tax Return 2014, ending

- Information about Form 1120 and its separate instructions is at www.irs.gov/form1120.

4 Schedule M-3 attached

\begin{tabular}{l|l} 
TYPE \\
\cline { 2 - 2 } OR \\
PRINT
\end{tabular}

Name

B Employer identification number

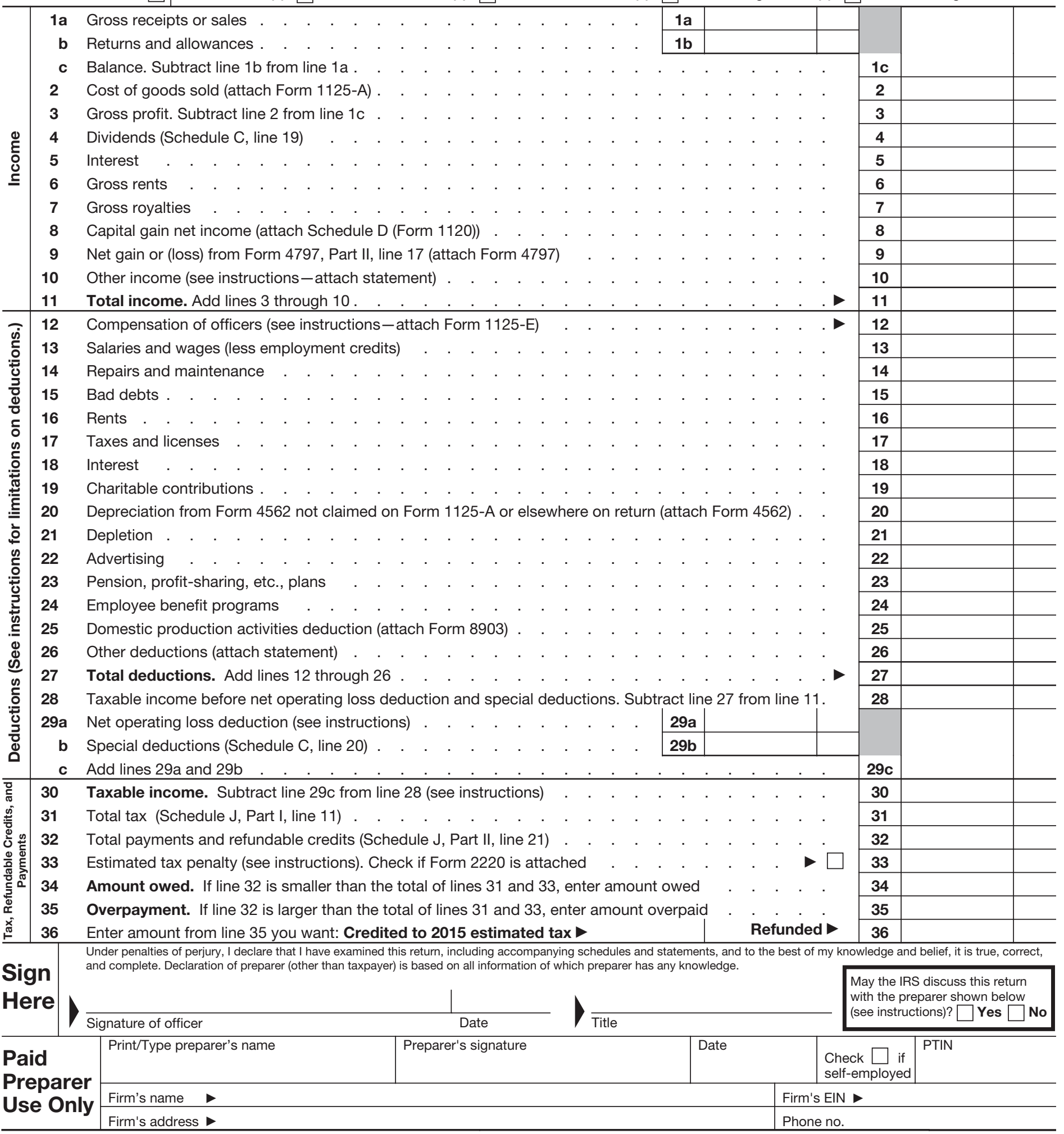

For Paperwork Reduction Act Notice, see separate instructions.

Cat. No. $11450 Q$

Form $1120(2014)$ 
1a Consolidated return (attach Form 851)

b Life/nonlife consolidated return .

2 Personal holding co. (attach Sch. PH) .

3 Personal service corp. (see instructions)

$\square$
$\square$
$\square$
$\square$
$\square$
$\square$

U.S. Corporation Income Tax Return 2014, ending

- Information about Form 1120 and its separate instructions is at www.irs.gov/form1120.

4 Schedule M-3 attached

\begin{tabular}{l|l} 
TYPE \\
\cline { 2 - 2 } OR \\
PRINT
\end{tabular}

Name

B Employer identification number

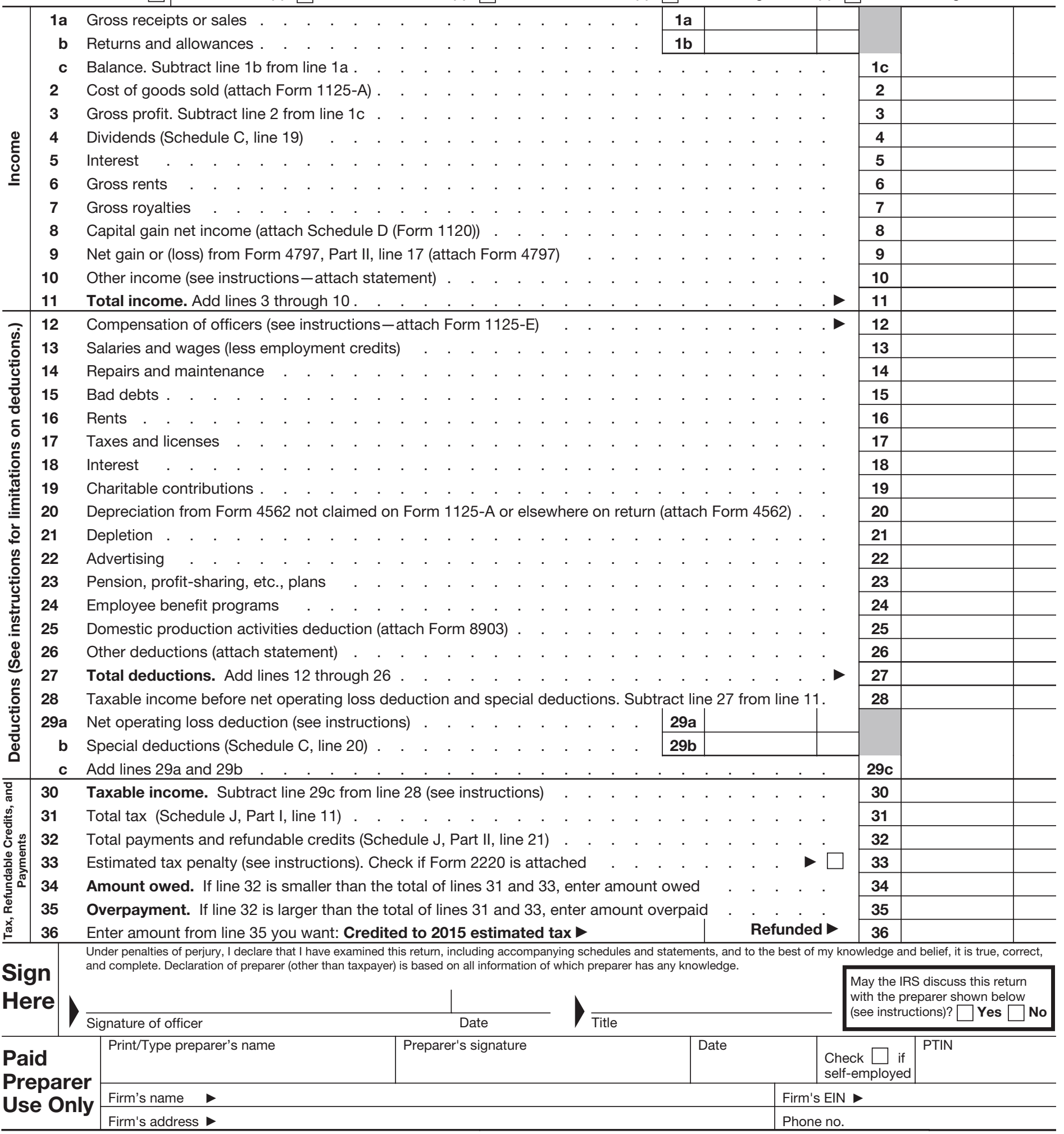

For Paperwork Reduction Act Notice, see separate instructions.

Cat. No. $11450 Q$

Form $1120(2014)$ 


\section{Schedule C Dividends and Special Deductions (see instructions)}

1 Dividends from less-than-20\%-owned domestic corporations (other than debt-financed stock)

2 Dividends from 20\%-or-more-owned domestic corporations (other than debt-financed stock)

3 Dividends on debt-financed stock of domestic and foreign corporations

4 Dividends on certain preferred stock of less-than-20\%-owned public utilities

5 Dividends on certain preferred stock of $20 \%$-or-more-owned public utilities . . . .

6 Dividends from less-than-20\%-owned foreign corporations and certain FSCs . . .

7 Dividends from $20 \%$-or-more-owned foreign corporations and certain FSCs

8 Dividends from wholly owned foreign subsidiaries

9 Total. Add lines 1 through 8. See instructions for limitation

10 Dividends from domestic corporations received by a small business investment company operating under the Small Business Investment Act of 1958

Dividends from affiliated group members .

Dividends from certain FSCs

Dividends from foreign corporations not included on lines $3,6,7,8,11$, or 12

Foreign dividend gross-up

Other dividends

Deduction for dividends paid on certain preferred stock of public utilities

Total dividends. Add lines 1 through 17. Enter here and on page 1, line 4 . . .

\begin{tabular}{|c|c|c|}
\hline \multirow[t]{2}{*}{$\begin{array}{l}\text { (a) Dividends } \\
\text { received }\end{array}$} & (b) \% & $\begin{array}{l}\text { (c) Special deductions } \\
\text { (a) } \times \text { (b) }\end{array}$ \\
\hline & 70 & \\
\hline & 80 & \\
\hline & $\begin{array}{c}\text { see } \\
\text { instructions }\end{array}$ & \\
\hline & 42 & \\
\hline & 48 & \\
\hline & 70 & \\
\hline & 80 & \\
\hline & 100 & \\
\hline & 100 & \\
\hline & 100 & \\
\hline & 100 & \\
\hline & & \\
\hline & & \\
\hline & & \\
\hline & & \\
\hline & & \\
\hline & & \\
\hline & & \\
\hline & 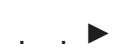 & \\
\hline
\end{tabular}


Schedule J

\section{Tax Computation and Payment (see instructions)}

\section{Part I-Tax Computation}

1 Check if the corporation is a member of a controlled group (attach Schedule O (Form 1120))

2 Income tax. Check if a qualified personal service corporation (see instructions).

3 Alternative minimum tax (attach Form 4626)

$4 \quad$ Add lines 2 and 3

5a Foreign tax credit (attach Form 1118)

b Credit from Form 8834 (see instructions)

c General business credit (attach Form 3800)

d Credit for prior year minimum tax (attach Form 8827)

e Bond credits from Form 8912

6 Total credits. Add lines 5 a through $5 e$

7 Subtract line 6 from line 4

8 Personal holding company tax (attach Schedule PH (Form 1120))

9a Recapture of investment credit (attach Form 4255)

b Recapture of low-income housing credit (attach Form 8611)

c Interest due under the look-back method-completed long-term contracts (attach Form 8697) .

d Interest due under the look-back method-income forecast method (attach Form 8866)

e Alternative tax on qualifying shipping activities (attach Form 8902)

f Other (see instructions-attach statement)

10 Total. Add lines 9a through $9 f$

11 Total tax. Add lines 7, 8, and 10. Enter here and on page 1, line 31

\section{Part II-Payments and Refundable Credits}

122013 overpayment credited to 2014

132014 estimated tax payments

142014 refund applied for on Form 4466.

15 Combine lines 12, 13, and 14

16 Tax deposited with Form 7004

17 Withholding (see instructions)

18 Total payments. Add lines 15, 16, and 17.

19 Refundable credits from:

a Form 2439

b Form 4136

c Form 8827, line 8c

d Other (attach statement-see instructions).

20 Total credits. Add lines 19a through 19d.

21 Total payments and credits. Add lines 18 and 20. Enter here and on page 1, line 32

\section{Schedule K Other Information (see instructions)}

\section{Check accounting method: a $\square$ Cash b $\square$ Accrual c $\square$ Other (specify)}

2 See the instructions and enter the:

a Business activity code no.

b Business activity

c Product or service

3 Is the corporation a subsidiary in an affiliated group or a parent-subsidiary controlled group? If "Yes," enter name and EIN of the parent corporation

4 At the end of the tax year:

a Did any foreign or domestic corporation, partnership (including any entity treated as a partnership), trust, or tax-exempt organization own directly $20 \%$ or more, or own, directly or indirectly, $50 \%$ or more of the total voting power of all classes of the corporation's stock entitled to vote? If "Yes," complete Part I of Schedule G (Form 1120) (attach Schedule G)

b Did any individual or estate own directly $20 \%$ or more, or own, directly or indirectly, $50 \%$ or more of the total voting power of all classes of the corporation's stock entitled to vote? If "Yes," complete Part II of Schedule G (Form 1120) (attach Schedule G) 
5 At the end of the tax year, did the corporation:

a Own directly $20 \%$ or more, or own, directly or indirectly, $50 \%$ or more of the total voting power of all classes of stock entitled to vote of any foreign or domestic corporation not included on Form 851, Affiliations Schedule? For rules of constructive ownership, see instructions. If "Yes," complete (i) through (iv) below.

\begin{tabular}{l|l|l|l}
\hline (i) Name of Corporation & $\begin{array}{c}\text { (ii) Employer } \\
\text { Identification Number } \\
\text { (if any) }\end{array}$ & $\begin{array}{c}\text { (iv) Percentage } \\
\text { Owned in Voting } \\
\text { Stock }\end{array}$ \\
\hline & & & \\
Incorporation of
\end{tabular}

b Own directly an interest of $20 \%$ or more, or own, directly or indirectly, an interest of $50 \%$ or more in any foreign or domestic partnership (including an entity treated as a partnership) or in the beneficial interest of a trust? For rules of constructive ownership, see instructions. If "Yes," complete (i) through (iv) below.

\begin{tabular}{l|c|c|c}
\hline (i) Name of Entity & $\begin{array}{c}\text { (ii) Employer } \\
\text { Identification Number } \\
\text { (if any) }\end{array}$ & $\begin{array}{c}\text { (iv) Maximum Country of } \\
\text { Organization } \\
\text { Profit, Loss, Owned in }\end{array}$ \\
\hline & & & \\
\hline
\end{tabular}

6 During this tax year, did the corporation pay dividends (other than stock dividends and distributions in exchange for stock) in excess of the corporation's current and accumulated earnings and profits? (See sections 301 and 316.)

If "Yes," file Form 5452, Corporate Report of Nondividend Distributions.

If this is a consolidated return, answer here for the parent corporation and on Form 851 for each subsidiary.

7 At any time during the tax year, did one foreign person own, directly or indirectly, at least $25 \%$ of (a) the total voting power of all classes of the corporation's stock entitled to vote or (b) the total value of all classes of the corporation's stock?

For rules of attribution, see section 318. If "Yes," enter:

(i) Percentage owned and (ii) Owner's country

(c) The corporation may have to file Form 5472, Information Return of a 25\% Foreign-Owned U.S. Corporation or a Foreign Corporation Engaged in a U.S. Trade or Business. Enter the number of Forms 5472 attached

8 Check this box if the corporation issued publicly offered debt instruments with original issue discount . . . . . . $\square$ If checked, the corporation may have to file Form 8281, Information Return for Publicly Offered Original Issue Discount Instruments.

9 Enter the amount of tax-exempt interest received or accrued during the tax year $\$$

10 Enter the number of shareholders at the end of the tax year (if 100 or fewer)

11 If the corporation has an NOL for the tax year and is electing to forego the carryback period, check here . . . . . $\square$ If the corporation is filing a consolidated return, the statement required by Regulations section 1.1502-21(b)(3) must be attached or the election will not be valid.

12 Enter the available NOL carryover from prior tax years (do not reduce it by any deduction on line 29a.) \$

13 Are the corporation's total receipts (page 1, line 1a, plus lines 4 through 10) for the tax year and its total assets at the end of the tax year less than $\$ 250,000$ ?

If "Yes," the corporation is not required to complete Schedules L, M-1, and M-2. Instead, enter the total amount of cash distributions and the book value of property distributions (other than cash) made during the tax year $\$$

14 Is the corporation required to file Schedule UTP (Form 1120), Uncertain Tax Position Statement (see instructions)?

If "Yes," complete and attach Schedule UTP.

15a Did the corporation make any payments in 2014 that would require it to file Form(s) 1099 ?

b If "Yes," did or will the corporation file required Forms 1099?

16 During this tax year, did the corporation have an $80 \%$ or more change in ownership, including a change due to redemption of its own stock?

17 During or subsequent to this tax year, but before the filing of this return, did the corporation dispose of more than $65 \%$ (by value) of its assets in a taxable, non-taxable, or tax deferred transaction?

18 Did the corporation receive assets in a section 351 transfer in which any of the transferred assets had a fair market basis or fair market value of more than $\$ 1$ million? 


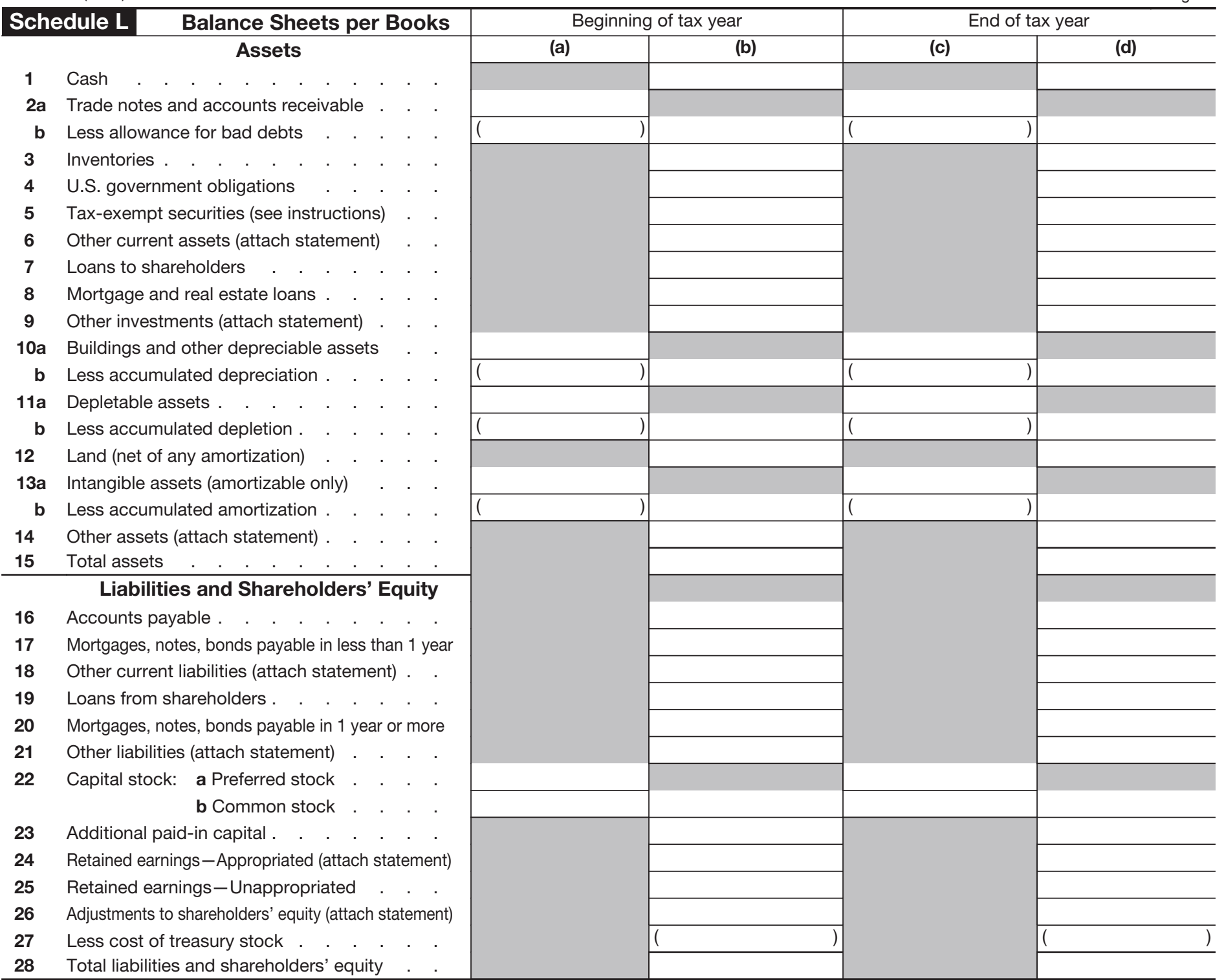

Schedule M-1 Reconciliation of Income (Loss) per Books With Income per Return

Note: The corporation may be required to file Schedule M-3 (see instructions).

\begin{abstract}
1 Net income (loss) per books
2 Federal income tax per books

3 Excess of capital losses over capital gains

4 Income subject to tax not recorded on books this year (itemize):
\end{abstract}

5 Expenses recorded on books this year not deducted on this return (itemize):

a Depreciation . . . . \$

b Charitable contributions. $\$$

c Travel and entertainment. \$

6 Add lines 1 through 5 .

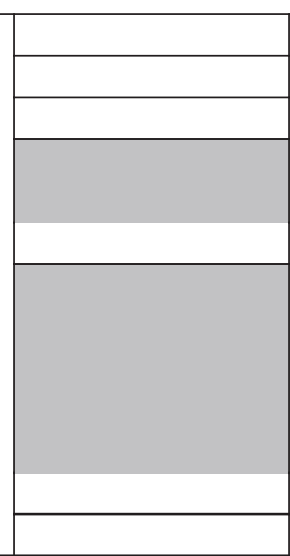

7 Income recorded on books this year not included on this return (itemize): Tax-exempt interest $\$$ $\$$

8 Deductions on this return not charged against book income this year (itemize):

a Depreciation . . \$

b Charitable contributions $\$$

$9 \quad$ Add lines 7 and 8

10 Income (page 1, line 28)-line 6 less line 9

Schedule M-2 Analysis of Unappropriated Retained Earnings per Books (Line 25, Schedule L)

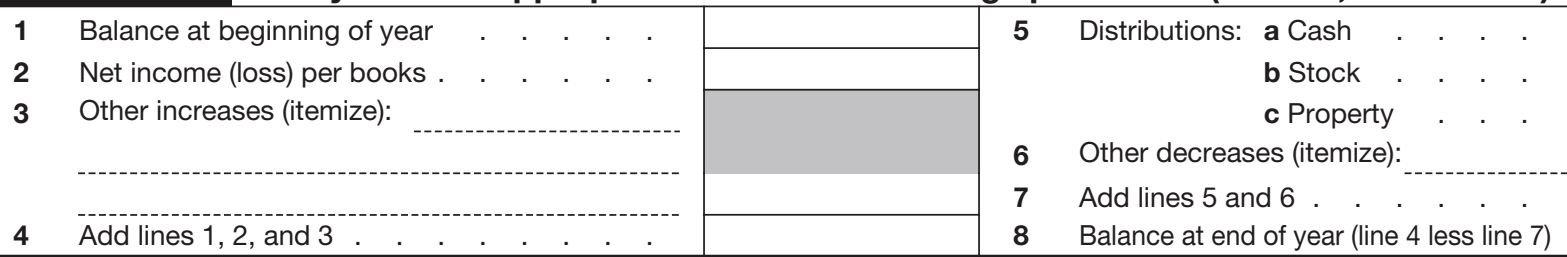


Schedule J

\section{Tax Computation and Payment (see instructions)}

\section{Part I-Tax Computation}

1 Check if the corporation is a member of a controlled group (attach Schedule O (Form 1120))

2 Income tax. Check if a qualified personal service corporation (see instructions).

3 Alternative minimum tax (attach Form 4626)

$4 \quad$ Add lines 2 and 3

5a Foreign tax credit (attach Form 1118)

b Credit from Form 8834 (see instructions)

c General business credit (attach Form 3800)

d Credit for prior year minimum tax (attach Form 8827)

e Bond credits from Form 8912

6 Total credits. Add lines 5 a through $5 e$

7 Subtract line 6 from line 4

8 Personal holding company tax (attach Schedule PH (Form 1120))

9a Recapture of investment credit (attach Form 4255)

b Recapture of low-income housing credit (attach Form 8611)

c Interest due under the look-back method-completed long-term contracts (attach Form 8697) .

d Interest due under the look-back method-income forecast method (attach Form 8866)

e Alternative tax on qualifying shipping activities (attach Form 8902)

f Other (see instructions-attach statement)

10 Total. Add lines 9a through $9 f$

11 Total tax. Add lines 7, 8, and 10. Enter here and on page 1, line 31

\section{Part II-Payments and Refundable Credits}

122013 overpayment credited to 2014

132014 estimated tax payments

142014 refund applied for on Form 4466.

15 Combine lines 12, 13, and 14

16 Tax deposited with Form 7004

17 Withholding (see instructions)

18 Total payments. Add lines 15, 16, and 17.

19 Refundable credits from:

a Form 2439

b Form 4136

c Form 8827, line 8c

d Other (attach statement-see instructions).

20 Total credits. Add lines 19a through 19d.

21 Total payments and credits. Add lines 18 and 20. Enter here and on page 1, line 32

\section{Schedule K Other Information (see instructions)}

\section{Check accounting method: a $\square$ Cash b $\square$ Accrual c $\square$ Other (specify)}

2 See the instructions and enter the:

a Business activity code no.

b Business activity

c Product or service

3 Is the corporation a subsidiary in an affiliated group or a parent-subsidiary controlled group? If "Yes," enter name and EIN of the parent corporation

4 At the end of the tax year:

a Did any foreign or domestic corporation, partnership (including any entity treated as a partnership), trust, or tax-exempt organization own directly $20 \%$ or more, or own, directly or indirectly, $50 \%$ or more of the total voting power of all classes of the corporation's stock entitled to vote? If "Yes," complete Part I of Schedule G (Form 1120) (attach Schedule G)

b Did any individual or estate own directly $20 \%$ or more, or own, directly or indirectly, $50 \%$ or more of the total voting power of all classes of the corporation's stock entitled to vote? If "Yes," complete Part II of Schedule G (Form 1120) (attach Schedule G) 
5 At the end of the tax year, did the corporation:

a Own directly $20 \%$ or more, or own, directly or indirectly, $50 \%$ or more of the total voting power of all classes of stock entitled to vote of any foreign or domestic corporation not included on Form 851, Affiliations Schedule? For rules of constructive ownership, see instructions. If "Yes," complete (i) through (iv) below.

\begin{tabular}{l|l|l|l}
\hline (i) Name of Corporation & $\begin{array}{c}\text { (ii) Employer } \\
\text { Identification Number } \\
\text { (if any) }\end{array}$ & $\begin{array}{c}\text { (iv) Percentage } \\
\text { Owned in Voting } \\
\text { Stock }\end{array}$ \\
\hline & & & \\
Incorporation of
\end{tabular}

b Own directly an interest of $20 \%$ or more, or own, directly or indirectly, an interest of $50 \%$ or more in any foreign or domestic partnership (including an entity treated as a partnership) or in the beneficial interest of a trust? For rules of constructive ownership, see instructions. If "Yes," complete (i) through (iv) below.

\begin{tabular}{l|c|c|c}
\hline (i) Name of Entity & $\begin{array}{c}\text { (ii) Employer } \\
\text { Identification Number } \\
\text { (if any) }\end{array}$ & $\begin{array}{c}\text { (iv) Maximum Country of } \\
\text { Organization } \\
\text { Profit, Loss, Owned in }\end{array}$ \\
\hline & & & \\
\hline
\end{tabular}

6 During this tax year, did the corporation pay dividends (other than stock dividends and distributions in exchange for stock) in excess of the corporation's current and accumulated earnings and profits? (See sections 301 and 316.)

If "Yes," file Form 5452, Corporate Report of Nondividend Distributions.

If this is a consolidated return, answer here for the parent corporation and on Form 851 for each subsidiary.

7 At any time during the tax year, did one foreign person own, directly or indirectly, at least $25 \%$ of (a) the total voting power of all classes of the corporation's stock entitled to vote or (b) the total value of all classes of the corporation's stock?

For rules of attribution, see section 318. If "Yes," enter:

(i) Percentage owned and (ii) Owner's country

(c) The corporation may have to file Form 5472, Information Return of a 25\% Foreign-Owned U.S. Corporation or a Foreign Corporation Engaged in a U.S. Trade or Business. Enter the number of Forms 5472 attached

8 Check this box if the corporation issued publicly offered debt instruments with original issue discount . . . . . . $\square$ If checked, the corporation may have to file Form 8281, Information Return for Publicly Offered Original Issue Discount Instruments.

9 Enter the amount of tax-exempt interest received or accrued during the tax year $\$$

10 Enter the number of shareholders at the end of the tax year (if 100 or fewer)

11 If the corporation has an NOL for the tax year and is electing to forego the carryback period, check here . . . . . $\square$ If the corporation is filing a consolidated return, the statement required by Regulations section 1.1502-21(b)(3) must be attached or the election will not be valid.

12 Enter the available NOL carryover from prior tax years (do not reduce it by any deduction on line 29a.) \$

13 Are the corporation's total receipts (page 1, line 1a, plus lines 4 through 10) for the tax year and its total assets at the end of the tax year less than $\$ 250,000$ ?

If "Yes," the corporation is not required to complete Schedules L, M-1, and M-2. Instead, enter the total amount of cash distributions and the book value of property distributions (other than cash) made during the tax year $\$$

14 Is the corporation required to file Schedule UTP (Form 1120), Uncertain Tax Position Statement (see instructions)?

If "Yes," complete and attach Schedule UTP.

15a Did the corporation make any payments in 2014 that would require it to file Form(s) 1099 ?

b If "Yes," did or will the corporation file required Forms 1099?

16 During this tax year, did the corporation have an $80 \%$ or more change in ownership, including a change due to redemption of its own stock?

17 During or subsequent to this tax year, but before the filing of this return, did the corporation dispose of more than $65 \%$ (by value) of its assets in a taxable, non-taxable, or tax deferred transaction?

18 Did the corporation receive assets in a section 351 transfer in which any of the transferred assets had a fair market basis or fair market value of more than $\$ 1$ million? 


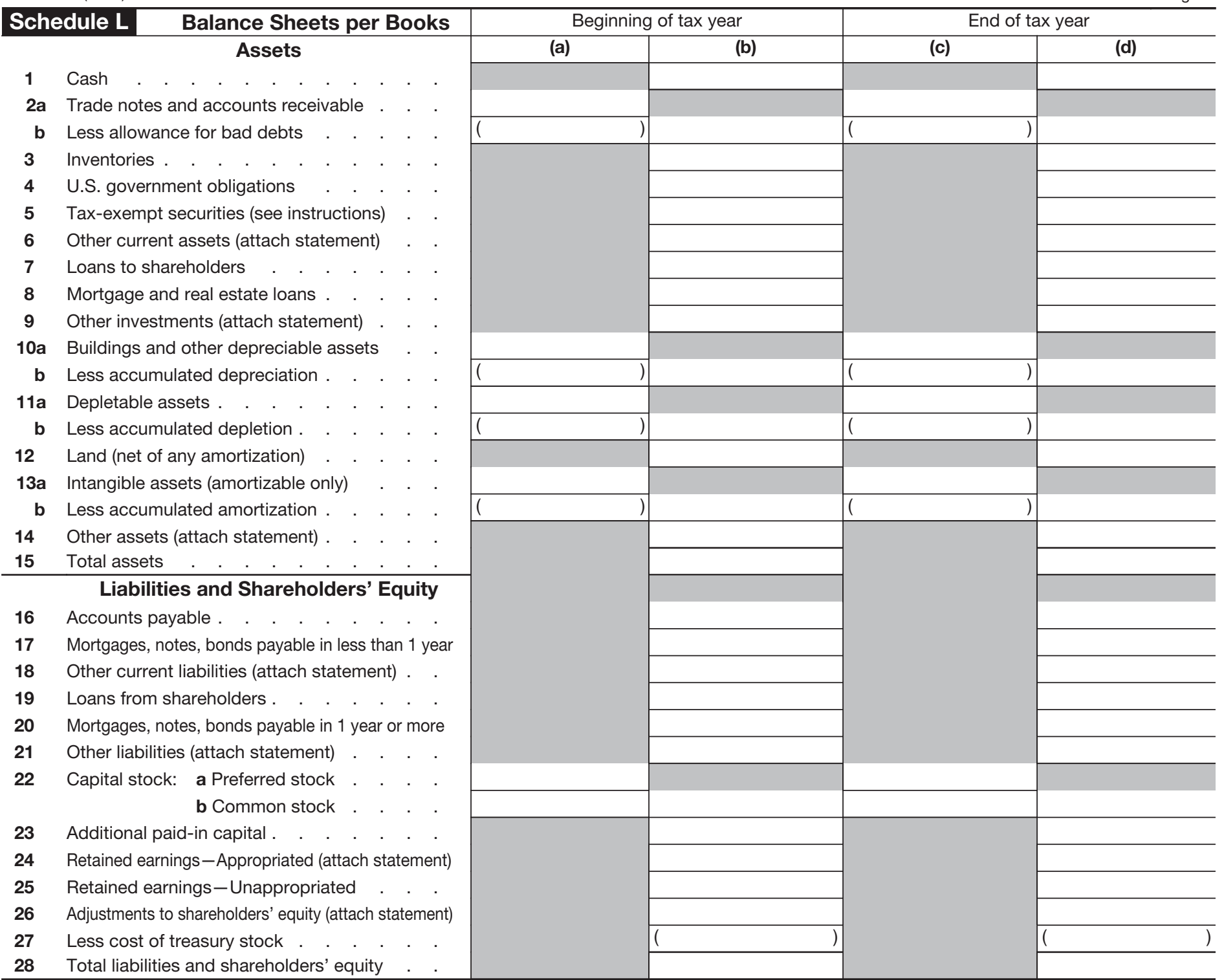

Schedule M-1 Reconciliation of Income (Loss) per Books With Income per Return

Note: The corporation may be required to file Schedule M-3 (see instructions).

\begin{abstract}
1 Net income (loss) per books
2 Federal income tax per books

3 Excess of capital losses over capital gains

4 Income subject to tax not recorded on books this year (itemize):
\end{abstract}

5 Expenses recorded on books this year not deducted on this return (itemize):

a Depreciation . . . . \$

b Charitable contributions. $\$$

c Travel and entertainment. \$

6 Add lines 1 through 5 .

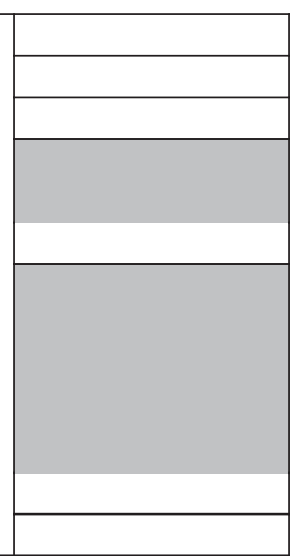

7 Income recorded on books this year not included on this return (itemize): Tax-exempt interest $\$$ $\$$

8 Deductions on this return not charged against book income this year (itemize):

a Depreciation . . \$

b Charitable contributions $\$$

$9 \quad$ Add lines 7 and 8

10 Income (page 1, line 28)-line 6 less line 9

Schedule M-2 Analysis of Unappropriated Retained Earnings per Books (Line 25, Schedule L)

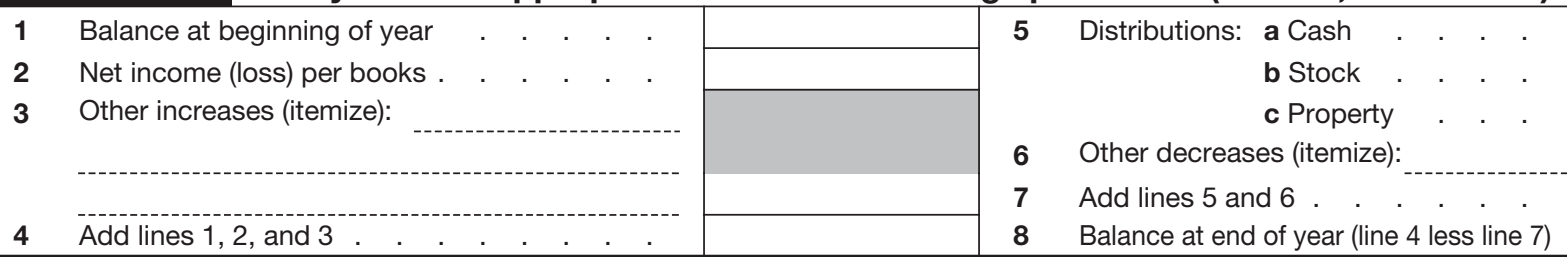


851

(Rev. December 2010)

Department of the Treasury

Internal Revenue Service

Name of common parent corporation

\section{Affiliations Schedule}

File with each consolidated income tax return.

For tax year ending

Number, street, and room or suite no. If a P.O. box, see instructions.

City or town, state, and ZIP code

Part I $\quad$ Overpayment Credits, Estimated Tax Payments, and Tax Deposits (see instructions)

\begin{tabular}{|c|c|c|c|c|}
\hline $\begin{array}{c}\text { Corp. } \\
\text { No. }\end{array}$ & Name and address of corporation & $\begin{array}{l}\text { Employer } \\
\text { identification } \\
\text { number }\end{array}$ & $\begin{array}{c}\text { Portion of } \\
\text { overpayment credits } \\
\text { and estimated } \\
\text { tax payments }\end{array}$ & $\begin{array}{l}\text { Portion of tax } \\
\text { deposited with } \\
\text { Form } 7004\end{array}$ \\
\hline 1 & Common parent corporation & & & \\
\hline 2 & Subsidiary corporations: & & & \\
\hline 3 & & & & \\
\hline 4 & & & & \\
\hline 5 & & & & \\
\hline 6 & & & & \\
\hline 7 & & & & \\
\hline 8 & & & & \\
\hline 9 & & & & \\
\hline 10 & & & & \\
\hline & Totals (Must equal amounts shown on the & F & & \\
\hline
\end{tabular}

Part II $\quad$ Principal Business Activity, Voting Stock Information, Etc. (see instructions)

\begin{tabular}{|c|c|c|c|c|c|c|c|c|}
\hline \multirow{3}{*}{$\begin{array}{c}\text { Corp. } \\
\text { No. }\end{array}$} & \multirow{3}{*}{ Principal business activity (PBA) } & \multirow{3}{*}{$\begin{array}{l}\text { PBA } \\
\text { Code } \\
\text { No. }\end{array}$} & \multirow{2}{*}{\multicolumn{2}{|c|}{\begin{tabular}{|c|} 
Did the subsidiary \\
make any nondividend \\
distributions?
\end{tabular}}} & \multicolumn{4}{|c|}{ Stock holdings at beginning of year } \\
\hline & & & & & \multirow{2}{*}{$\begin{array}{l}\text { Number } \\
\text { of } \\
\text { shares }\end{array}$} & \multirow{2}{*}{$\begin{array}{l}\text { Percent of } \\
\text { voting power }\end{array}$} & \multirow{2}{*}{$\begin{array}{c}\text { Percent of } \\
\text { value }\end{array}$} & \multirow{2}{*}{$\begin{array}{c}\text { Owned by } \\
\text { corporation } \\
\text { no. }\end{array}$} \\
\hline & & & Yes & No & & & & \\
\hline 1 & Common parent corporation & & & & & & & \\
\hline 2 & Subsidiary corporations: & & & & & $\%$ & $\%$ & \\
\hline 3 & & & & & & $\%$ & $\%$ & \\
\hline 4 & & & & & & $\%$ & $\%$ & \\
\hline 5 & & & & & & $\%$ & $\%$ & \\
\hline 6 & & & & & & $\%$ & $\%$ & \\
\hline 7 & & & & & & $\%$ & $\%$ & \\
\hline 8 & & & & & & $\%$ & $\%$ & \\
\hline 9 & & & & & & $\%$ & $\%$ & \\
\hline 10 & & & & & & $\%$ & $\%$ & \\
\hline
\end{tabular}




\section{Part III Changes in Stock Holdings During the Tax Year}

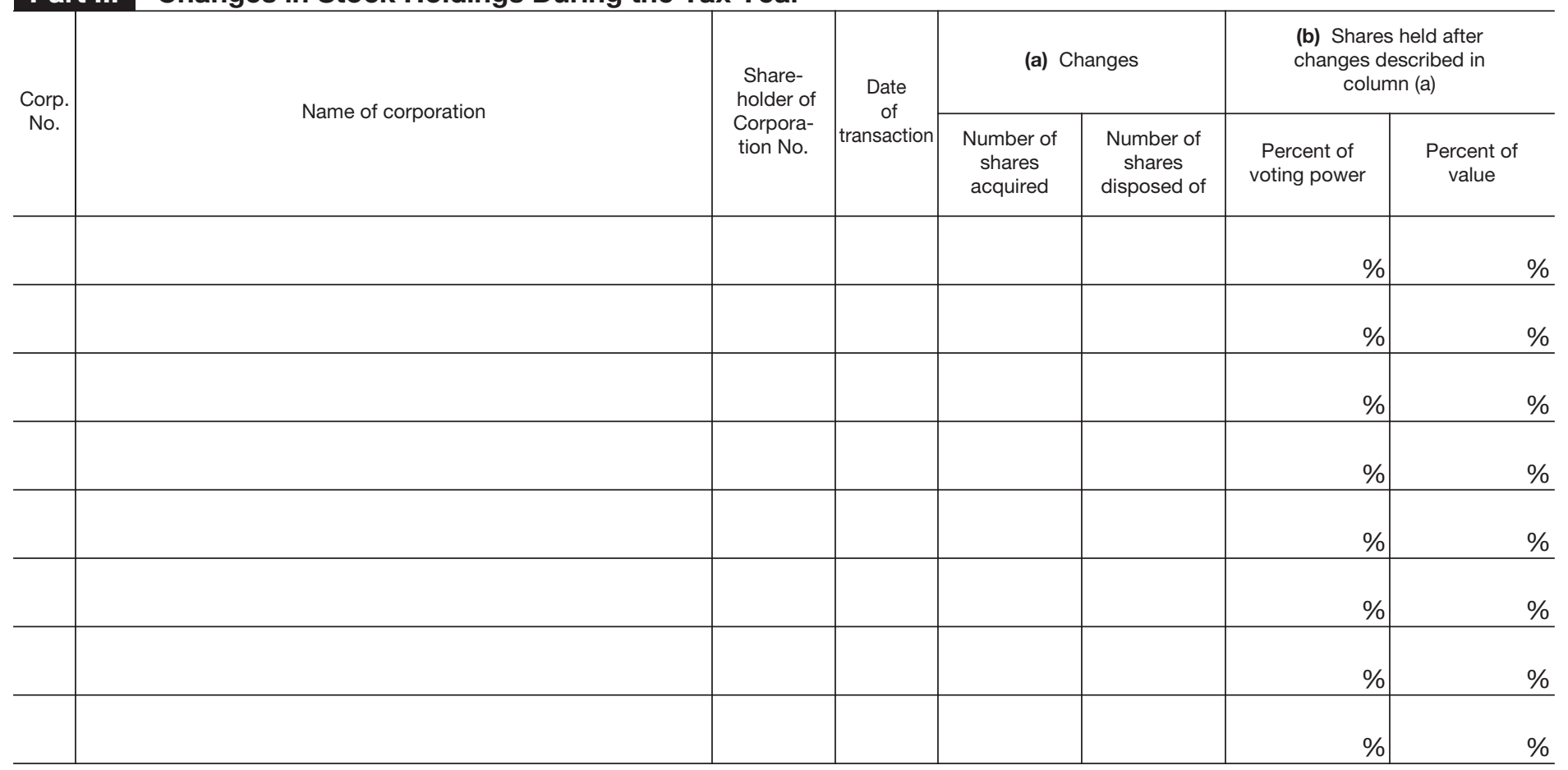

(c) If any transaction listed above caused a transfer of a share of subsidiary stock (defined to include dispositions and deconsolidations), did the share's basis exceed its value at the time of the transfer? See instructions

(d) Did any share of subsidiary stock become worthless within the meaning of section 165 (taking into account the provisions of Regulations section 1.1502-80(c)) during the taxable year? See instructions . . . .

(e) If the equitable owners of any capital stock shown above were other than the holders of record, provide details of the changes.

(f) If additional stock was issued, or if any stock was retired during the year, list the dates and amounts of these transactions. 
Part IV Additional Stock Information (see instructions)

1 During the tax year, did the corporation have more than one class of stock outstanding? If "Yes," enter the name of the corporation and list and describe each class of stock.

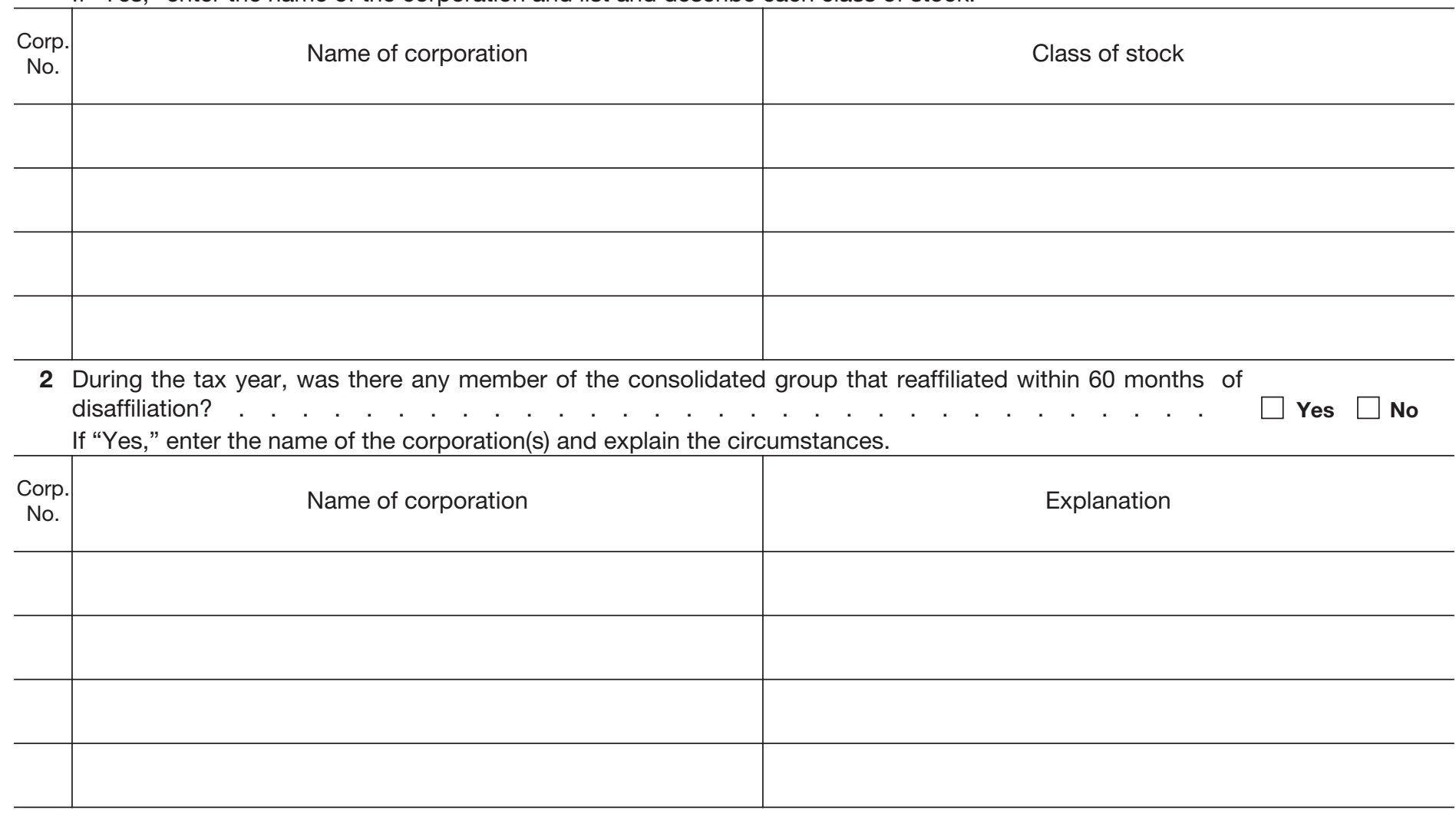

3 During the tax year, was there any arrangement in existence by which one or more persons that were not members of the affiliated group could acquire any stock, or acquire any voting power without acquiring stock, in the corporation, other than a de minimis amount, from the corporation or another member of the affiliated group?

If "Yes," enter the name of the corporation and see the instructions for the percentages to enter in columns (a), (b), and (c).

\begin{tabular}{r|r|r|r|r}
\hline $\begin{array}{c}\text { Corp. } \\
\text { No. }\end{array}$ & Name of corporation & $\begin{array}{c}\text { (a) } \\
\text { Percent of value }\end{array}$ & $\begin{array}{c}\text { (b) } \\
\text { Percent of outstanding } \\
\text { voting stock }\end{array}$ & $\begin{array}{c}\text { Percent of voting } \\
\text { power }\end{array}$ \\
\hline & $\%$ & $\%$ & $\%$ \\
\hline & $\%$ & $\%$ & $\%$ \\
\hline
\end{tabular}

No. (d) Provide a description of any arrangement. 


\section{Instructions}

Section references are to the Internal Revenue Code unless otherwise noted.

\section{Purpose of Form}

Use Form 851 to:

1. Identify the common parent corporation and each member of the affiliated group;

2. Report the amount of overpayment credits, estimated tax payments, and tax deposits attributable to each corporation; and

3. Determine that each subsidiary corporation qualifies as a member of the affiliated group.

\section{Who Must File}

The parent corporation must file Form 851 for itself and for corporations in the affiliated group. File Form 851 by attaching it to the consolidated tax return for the group.

\section{Affiliated Group}

An affiliated group is one or more chains of includible corporations connected through stock ownership with a common parent corporation. See sections 1504(a) and (b). The common parent must be an includible corporation and the following requirements must be met.

1. The common parent must own directly stock that represents at least $80 \%$ of the total voting power and at least $80 \%$ of the total value of the stock of at least one of the other includible corporations.

2. Stock that represents at least $80 \%$ of the total voting power, and at least $80 \%$ of the total value of the stock of each of the other corporations (except for the common parent) must be owned directly by one or more of the other includible corporations.

For this purpose, the term "stock" generally does not include any stock that:

1. Is nonvoting,

2. Is nonconvertible,

3. Is limited and preferred as to dividends and does not participate significantly in corporate growth, and

4. Has redemption and liquidation rights that do not exceed the issue price of the stock (except for a reasonable redemption or liquidation premium).

\section{Address}

Include the suite, room, or other unit number after the street address. If the Post Office does not deliver mail to the street address and the corporation has a P.O. box, show the box number instead.

\section{Corporation Numbers}

When listing information in Parts II, III, and IV, use the same number for the common parent corporation and for each subsidiary corporation as the number listed in Part I.

\section{Part I}

Portion of overpayment credits and estimated tax payments. Enter for the common parent corporation and for each subsidiary corporation the amount of:

- Overpayments of tax from the prior tax year that each corporation elected to credit to the current year's tax, and

- Estimated tax payments made by each corporation.

The total must be the same as the amounts entered on the lines for overpayments and estimated tax payments on the consolidated income tax return.

Tax deposited with Form 7004. Enter for the common parent the tax deposited with Form 7004, Application for Automatic 6-Month Extension of Time To File Certain Business, Income Tax, Information, and other Returns, that is attributable to each corporation. The total must be the same as the amount entered on the "Tax deposited with Form 7004" line on the consolidated income tax return.

\section{Part II}

Principal Business Activity (PBA) and PBA Code No. Enter the PBA and the PBA code number for the common parent corporation and for each subsidiary corporation. Use the activity for the specific industry group from which the largest percentage of each corporation's total receipts is based.

A list of the PBAs and code numbers is located in the Instructions for Form 1120. Nondividend distributions. Nondividend distributions are any distributions (other than stock dividends and distributions in exchange for stock) made to shareholders during the tax year for which the consolidated tax return is filed that were in excess of the corporation's current and accumulated earnings and profits. See sections 301 and 316 and Form 5452, Corporate Report of Nondividend Distributions.

\section{Part III}

Question (c). For this purpose, the term "transfer" includes transactions in which (1) a shareholder-member ceases to own a share of subsidiary stock in a transaction in which the shareholder-member recognizes income, gain, deduction, or loss on the stock; (2) a shareholder-member and the subsidiary cease to be members of the same consolidated group; and (3) a non-member acquires the share from a member. If any type of transfer occurs and the share's basis would otherwise exceed its value at the time of the transfer, certain adjustments to members' bases in shares of the subsidiary's stock and to the subsidiary's attributes may be required. See Regulations section 1.1502-36.

Question (d). If a share of subsidiary stock becomes worthless within the meaning of section 165 (taking into account the provisions of Regulations section $1.1502-80$ (c)) during the group's taxable year, certain adjustments to shareholder-members bases in shares of the subsidiary's stock and/ or to the subsidiary's attributes may be required. See Regulations sections 1.1502-19 (b)(1)(iv) (if the basis of the share is equal to or less than zero) and 1.1502-36 (if the basis of the share is greater than zero).
Item (e). The term "equitable owners" of stock means those that essentially have all the rights to enjoy the benefits of stock ownership without actually holding the stock, e.g., beneficiary of a trust.

\section{Part IV}

Question 1. For purposes of question 1 only, disregard certain preferred stock as described in section 1504(a)(4).

Question 3. The term "arrangement" includes, but is not limited to, phantom stock, stock appreciation rights, an option, warrant, conversion feature, or similar arrangements. Item 3a. Show the percentage of the value of the outstanding stock that the person(s) could acquire.

Item $\mathbf{3 b}$. If the arrangement was associated with voting stock, show the percentage of outstanding voting stock that the person(s) could acquire.

Item $\mathbf{3 c}$. If the arrangement was associated with the acquisition of voting power without the acquisition of the related stock, show the percentage of voting power that the person(s) could acquire.

Item 3d. Give a brief description of any arrangement (defined above) by which a person that is not a member of the affiliated group could acquire any stock, or acquire any voting power without acquiring stock, in the corporation.

\section{Paperwork Reduction}

\section{Act Notice}

We ask for the information on this form to carry out the Internal Revenue laws of the United States. You are required to give us the information. We need it to ensure that you are complying with these laws and to allow us to figure and collect the right amount of tax.

You are not required to provide the information requested on a form that is subject to the Paperwork Reduction Act unless the form displays a valid OMB control number. Books or records relating to a form or its instructions must be retained as long as their contents may become material in the administration of any Internal Revenue law. Generally, tax returns and return information are confidential, as required by section 6103 .

The time needed to complete and file this form will vary depending on individual circumstances. The estimated average time is:

Recordkeeping . . . . $10 \mathrm{hr} ., 45 \mathrm{~min}$. Learning about the law or the form $53 \min$

Preparing and sending

the form to the IRS . . . . $1 \mathrm{hr}$., $6 \mathrm{~min}$

If you have comments concerning the accuracy of these time estimates or suggestions for making this form simpler, we would be happy to hear from you. See the instructions for the tax return with which this form is filed. 


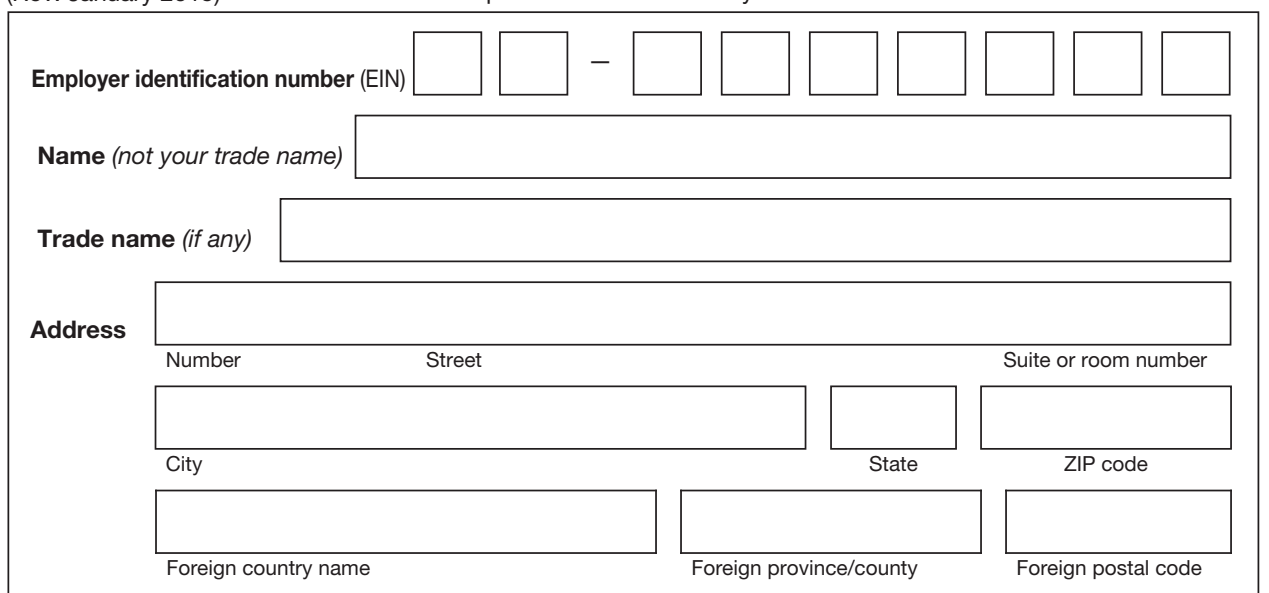

Read the separate instructions before you complete Form 941. Type or print within the boxes.

\section{Part 1: Answer these questions for this quarter.}

1 Number of employees who received wages, tips, or other compensation for the pay period including: Mar. 12 (Quarter 1), June 12 (Quarter 2), Sept. 12 (Quarter 3), or Dec. 12 (Quarter 4)

1

2

3

Check and go to line 6.
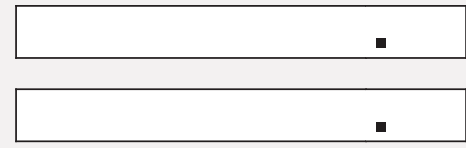

4 If no wages, tips, and other compensation are subject to social security or Medicare tax

Report for this Quarter of 2015 (Check one.)

1: January, February, March

2: April, May, June

3: July, August, September

4: October, November, December Instructions and prior year forms are available at www.irs.gov/form 941 .

2 Wages, tips, and other compensation

Federal income tax withheld from wages, tips, and other compensation

Column 1

5a Taxable social security wages . .

5b Taxable social security tips . . .

5c Taxable Medicare wages \& tips.
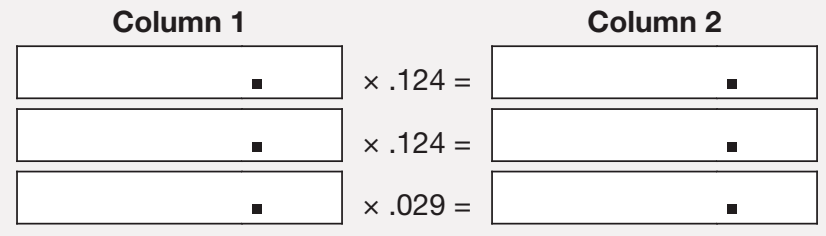

$5 d$ Taxable wages \& tips subject to Additional Medicare Tax withholding

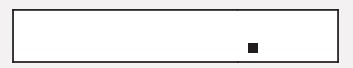

$\times .009=$

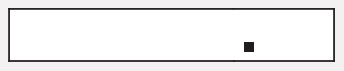

5e Add Column 2 from lines 5a, 5b, 5c, and 5d

$5 e$

5 Section 3121(q) Notice and Demand-Tax due on unreported tips (see instructions)

$5 f$

6 Total taxes before adjustments. Add lines $3,5 e$, and $5 f$

6

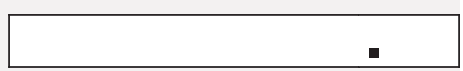

7 Current quarter's adjustment for fractions of cents

7

8

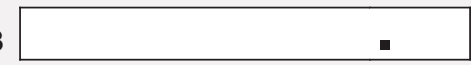

8 Current quarter's adjustment for sick pay

9

10

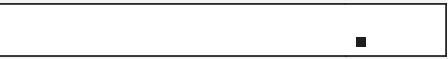

Current quarter's adjustments for tips and group-term life insurance

10 Total taxes after adjustments. Combine lines 6 through 9

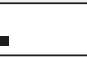

11 Total deposits for this quarter, including overpayment applied from a prior quarter and overpayments applied from Form 941-X, 941-X (PR), 944-X, 944-X (PR), or 944-X (SP) filed in the current quarter.

12 Balance due. If line 10 is more than line 11, enter the difference and see instructions

\section{1}

12 Check one: Apply to next return. Send a refund. 
Part 2: Tell us about your deposit schedule and tax liability for this quarter.

If you are unsure about whether you are a monthly schedule depositor or a semiweekly schedule depositor, see Pub. 15 (Circular E), section 11.

14 Check one:

Line 10 on this return is less than $\$ 2,500$ or line 10 on the return for the prior quarter was less than $\$ 2,500$, and you did not incur a $\$ 100,000$ next-day deposit obligation during the current quarter. If line 10 for the prior quarter was less than $\$ 2,500$ but line 10 on this return is $\$ 100,000$ or more, you must provide a record of your federal tax liability. If you are a monthly schedule depositor, complete the deposit schedule below; if you are a semiweekly schedule depositor, attach Schedule B (Form 941). Go to Part 3.

$\square$ You were a monthly schedule depositor for the entire quarter. Enter your tax liability for each month and total liability for the quarter, then go to Part 3.

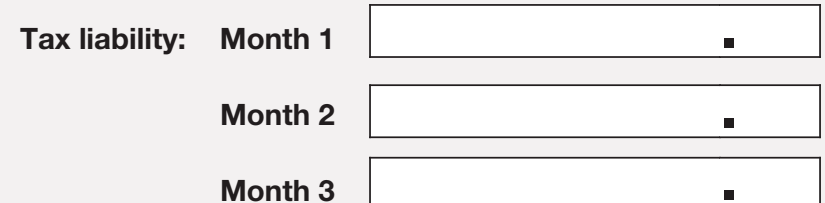

Total liability for quarter

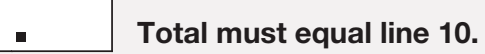

You were a semiweekly schedule depositor for any part of this quarter. Complete Schedule B (Form 941), Report of Tax Liability for Semiweekly Schedule Depositors, and attach it to Form 941.

Part 3: Tell us about your business. If a question does NOT apply to your business, leave it blank.

15 If your business has closed or you stopped paying wages .

Check here, and enter the final date you paid wages

$1 / 1$.

16 If you are a seasonal employer and you do not have to file a return for every quarter of the year . . $\square$ Check here.

\section{Part 4: May we speak with your third-party designee?}

Do you want to allow an employee, a paid tax preparer, or another person to discuss this return with the IRS? See the instructions for details.

Yes. Designee's name and phone number
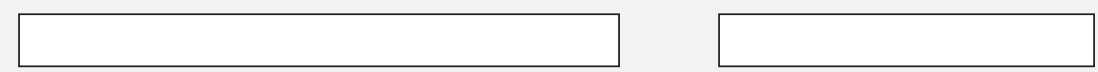

Select a 5-digit Personal Identification Number (PIN) to use when talking to the IRS.

No.

\section{Part 5: Sign here. You MUST complete both pages of Form 941 and SIGN it.}

Under penalties of perjury, I declare that I have examined this return, including accompanying schedules and statements, and to the best of my knowledge and belief, it is true, correct, and complete. Declaration of preparer (other than taxpayer) is based on all information of which preparer has any knowledge.

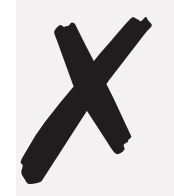

\section{Sign your name here}

Date
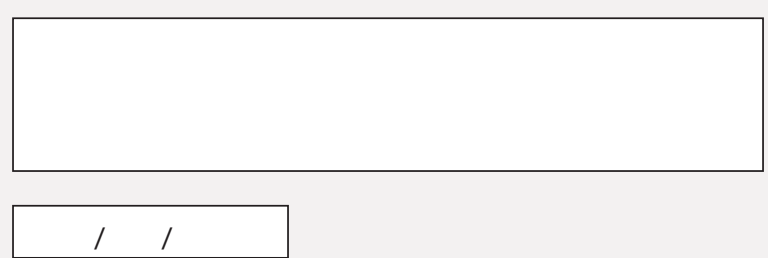

Print your name here

Print your title here

Best daytime phone

\section{Paid Preparer Use Only}

Preparer's name

\section{Preparer's signature}

Firm's name (or yours if self-employed)

Address

City

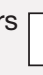

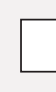
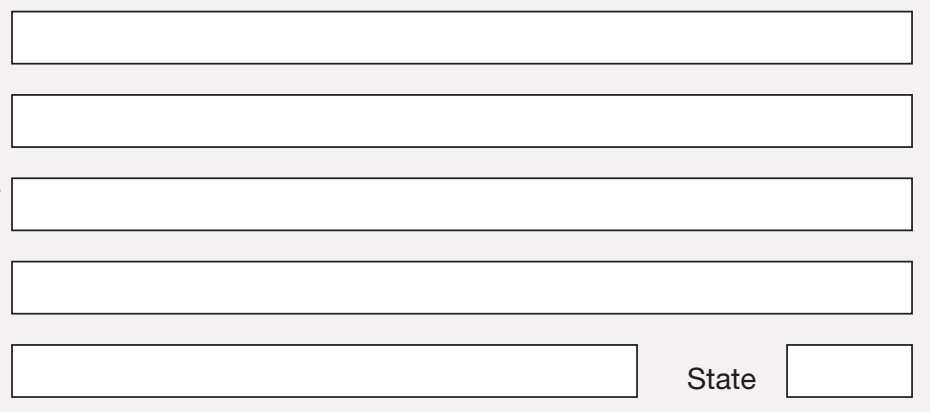

State
Check if you are self-employed

PTIN
Date
EIN
Phone
ZIP code




\section{Form 941-V,}

\section{Payment Voucher}

\section{Purpose of Form}

Complete Form 941-V, Payment Voucher, if you are making a payment with Form 941, Employer's QUARTERLY Federal Tax Return. We will use the completed voucher to credit your payment more promptly and accurately, and to improve our service to you.

\section{Making Payments With Form 941}

To avoid a penalty, make your payment with Form 941 only if:

- Your total taxes after adjustments for either the current quarter or the preceding quarter (Form 941, line 10) are less than $\$ 2,500$, you did not incur a $\$ 100,000$ next-day deposit obligation during the current quarter, and you are paying in full with a timely filed return, or

- You are a monthly schedule depositor making a payment in accordance with the Accuracy of Deposits Rule. See section 11 of Pub. 15 (Circular E), Employer's Tax Guide, for details. In this case, the amount of your payment may be $\$ 2,500$ or more.

Otherwise, you must make deposits by electronic funds transfer. See section 11 of Pub. 15 (Circular E) for deposit instructions. Do not use Form 941-V to make federal tax deposits.

Caution. Use Form 941-V when making any payment with Form 941. However, if you pay an amount with Form 941 that should have been deposited, you may be subject to a penalty. See Deposit Penalties in section 11 of Pub. 15 (Circular E).

\section{Specific Instructions}

Box 1-Employer identification number (EIN). If you do not have an EIN, you may apply for one online. Go to IRS.gov and type "EIN" in the search box. You may also apply for an EIN by faxing or mailing Form SS-4, Application for Employer Identification Number, to the IRS. If you have not received your EIN by the due date of Form 941, write "Applied For" and the date you applied in this entry space.

Box 2-Amount paid. Enter the amount paid with Form 941.

Box 3-Tax period. Darken the circle identifying the quarter for which the payment is made. Darken only one circle.

Box 4-Name and address. Enter your name and address as shown on Form 941.

- Enclose your check or money order made payable to the "United States Treasury." Be sure to enter your EIN, "Form 941," and the tax period on your check or money order. Do not send cash. Do not staple Form 941-V or your payment to Form 941 (or to each other).

- Detach Form 941-V and send it with your payment and Form 941 to the address in the Instructions for Form 941.

Note. You must also complete the entity information above Part 1 on Form 941. 
Privacy Act and Paperwork Reduction Act Notice. We ask for the information on Form 941 to carry out the Internal Revenue laws of the United States. We need it to figure and collect the right amount of tax. Subtitle C, Employment Taxes, of the Internal Revenue Code imposes employment taxes on wages and provides for income tax withholding. Form 941 is used to determine the amount of taxes that you owe. Section 6011 requires you to provide the requested information if the tax is applicable to you. Section 6109 requires you to provide your identification number. If you fail to provide this information in a timely manner, or provide false or fraudulent information, you may be subject to penalties.

You are not required to provide the information requested on a form that is subject to the Paperwork Reduction Act unless the form displays a valid OMB control number. Books and records relating to a form or its instructions must be retained as long as their contents may become material in the administration of any Internal Revenue law.

Generally, tax returns and return information are confidential, as required by section 6103 . However, section 6103 allows or requires the IRS to disclose or give the information shown on your tax return to others as described in the Code. For example, we may disclose your tax information to the Department of
Justice for civil and criminal litigation, and to cities, states, the District of Columbia, and U.S. commonwealths and possessions for use in administering their tax laws. We may also disclose this information to other countries under a tax treaty, to federal and state agencies to enforce federal nontax criminal laws, or to federal law enforcement and intelligence agencies to combat terrorism.

The time needed to complete and file Form 941 will vary depending on individual circumstances. The estimated average time is:

Recordkeeping . . . . . . . . . . . . . $11 \mathrm{hr}$. Learning about the law or the form . . . . $47 \mathrm{~min}$. Preparing, copying, assembling, and sending the form to the IRS . . . . . . . . $1 \mathrm{hr}$.

If you have comments concerning the accuracy of these time estimates or suggestions for making Form 941 simpler, we would be happy to hear from you. You can send us comments from www.irs.gov/formspubs. Click on More Information and then click on Give us feedback. Or you can send your comments to Internal Revenue Service, Tax Forms and Publications Division, 1111 Constitution Ave. NW, IR-6526, Washington, DC 20224. Do not send Form 941 to this address. Instead, see Where Should You File? in the Instructions for Form 941. 


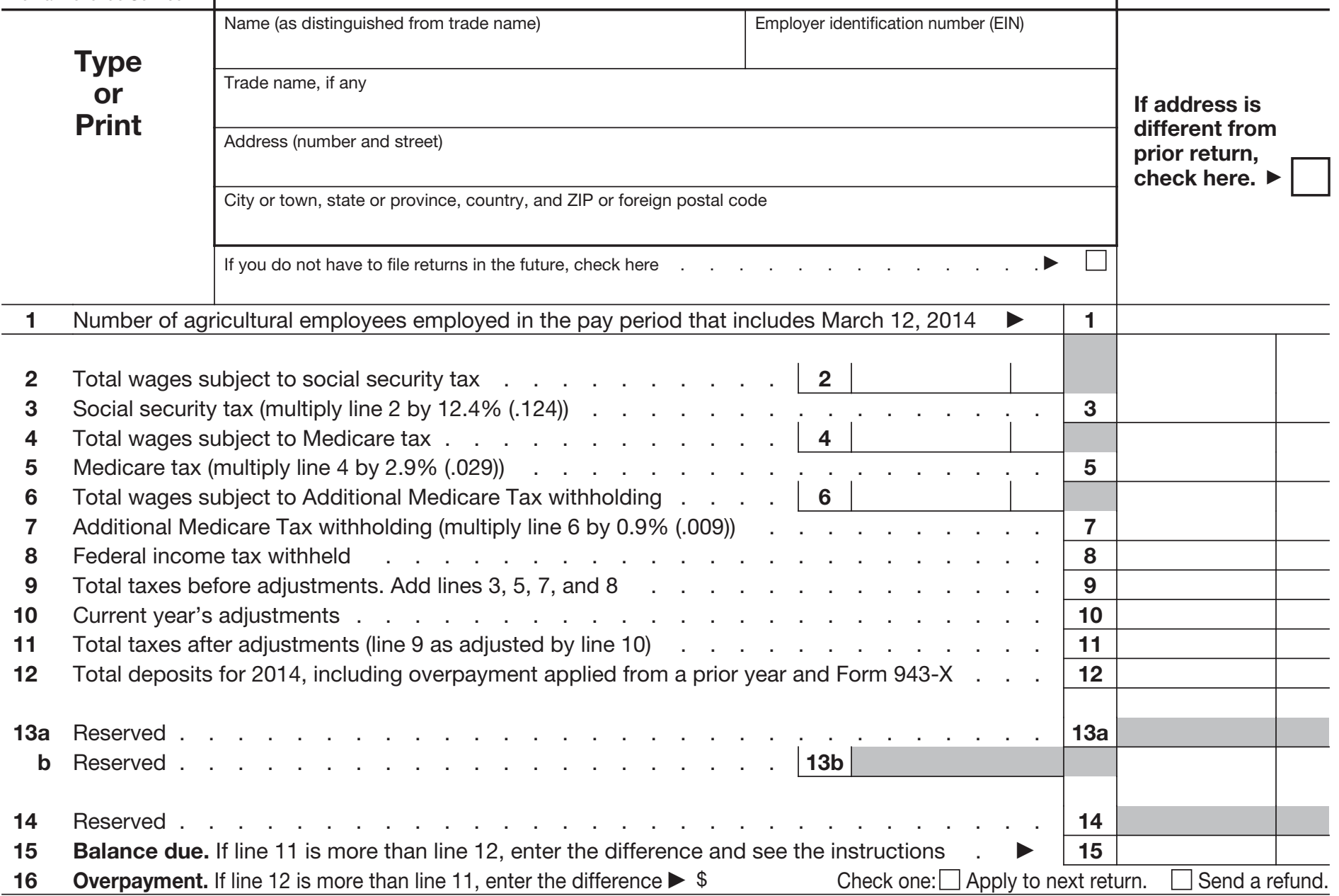

- All filers: If line 11 is less than $\$ 2,500$, do not complete line 17 or Form 943-A.

- Semiweekly schedule depositors: Complete Form 943-A and check here $\square$ • Monthly schedule depositors: Complete line 17 and check here $\square$

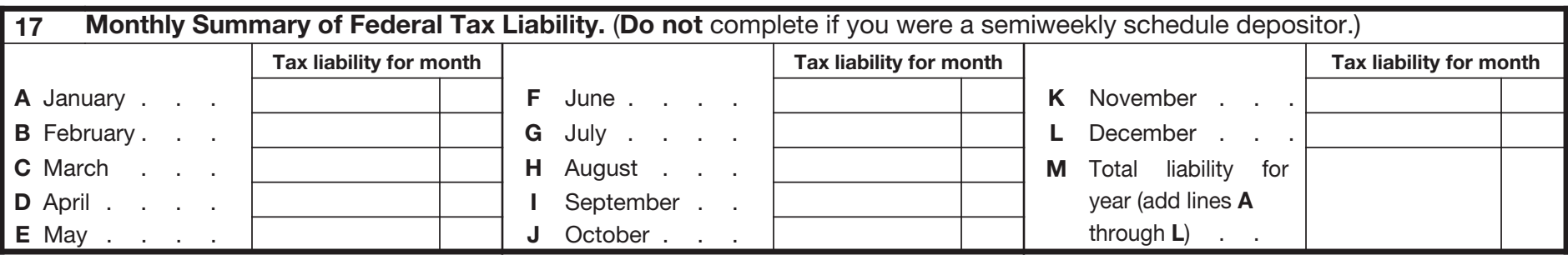

\begin{tabular}{|c|c|c|c|c|c|c|}
\hline \multirow{2}{*}{$\begin{array}{l}\text { Third- } \\
\text { Party } \\
\text { Designee }\end{array}$} & \multicolumn{3}{|c|}{ Do you want to allow another person to discuss this return with the IRS (see separate instructions)? } & \multicolumn{3}{|c|}{$\square$ Yes. Complete the following. $\square$ No. } \\
\hline & \multicolumn{3}{|l|}{$\begin{array}{l}\text { Designee's } \\
\text { name }\end{array}$} & $\begin{array}{l}\text { Personal identification } \\
\text { number (PIN) }\end{array}$ & & \\
\hline \multirow{2}{*}{$\begin{array}{l}\text { Sign } \\
\text { Here }\end{array}$} & \multicolumn{6}{|c|}{$\begin{array}{l}\text { Under penalties of perjury, I declare that I have examined this return, including accompanying schedules and statements, and to the best of my knowledge } \\
\text { and belief, it is true, correct, and complete. Declaration of preparer (other than taxpayer) is based on all information of which preparer has any knowledge. }\end{array}$} \\
\hline & Signature $>$ & \multicolumn{2}{|c|}{$\begin{array}{l}\text { Print Your } \\
\text { Name and Title }\end{array}$} & \multicolumn{3}{|c|}{ Date $\mathbf{~}$} \\
\hline \multirow{3}{*}{$\begin{array}{l}\text { Paid } \\
\text { Preparer } \\
\text { Use Only }\end{array}$} & Print/Type preparer's name & Preparer's signature & Date & $\begin{array}{l}\text { Check } \square \text { if } \\
\text { self-employed }\end{array}$ & PTIN & \\
\hline & \multicolumn{3}{|l|}{ Firm's name } & \multicolumn{3}{|l|}{ Firm's EIN $\downarrow$} \\
\hline & \multicolumn{3}{|l|}{ Firm's address } & \multicolumn{3}{|l|}{ Phone no. } \\
\hline
\end{tabular}




\section{Form 943-V, Payment Voucher}

\section{Purpose of Form}

Complete Form 943-V, Payment Voucher, if you are making a payment with Form 943, Employer's Annual Federal Tax Return for Agricultural Employees. We will use the completed voucher to credit your payment more promptly and accurately, and to improve our service to you.

\section{Making Payment With Form 943}

To avoid a penalty, make your payment with your 2014 Form 943 only if:

- Your total taxes after adjustments for the year (Form 943 , line 11) are less than $\$ 2,500$ and you are paying in full with a timely filed return, or

- You are a monthly schedule depositor making a payment in accordance with the Accuracy of Deposits Rule. See section 7 of Pub. 51 (Circular A), Agricultural Employer's Tax Guide, for details. In this case, the amount of your payment may be $\$ 2,500$ or more.

Otherwise, you must make deposits by electronic funds transfer. See section 7 of Pub. 51 (Circular A) for deposit instructions. Do not use Form $943-\mathrm{V}$ to make federal tax deposits.

Caution. Use Form 943-V when making any payment with Form 943. However, if you pay an amount with Form 943 that should have been deposited, you may be subject to a penalty. See Deposit Penalties in section 7 of Pub. 51 (Circular A).

\section{Specific Instructions}

Box 1-Employer identification number (EIN). If you do not have an EIN, you may apply for one online. Go to IRS.gov and type "EIN" in the search box. You may also apply for an EIN by faxing or mailing Form SS-4, Application for Employer Identification Number, to the IRS. If you have not received your EIN by the due date of Form 943, write "Applied For" and the date you applied in this entry space.

Box 2-Amount paid. Enter the amount paid with Form 943.

Box 3-Name and address. Enter your name and address as shown on Form 943.

- Enclose your check or money order made payable to "United States Treasury." Be sure to enter your EIN, "Form 943," and "2014" on your check or money order. Do not send cash. Do not attach Form 943-V or your payment to Form 943 (or to each other).

- Detach Form 943-V and send it with your payment and Form 943 to the address provided in the Instructions for Form 943.

Note. You must also complete the entity information above line 1 on Form 943.

\section{St $\nabla$ Detach Here and Mail With Your Payment and Form 943. $\nabla$ fo}

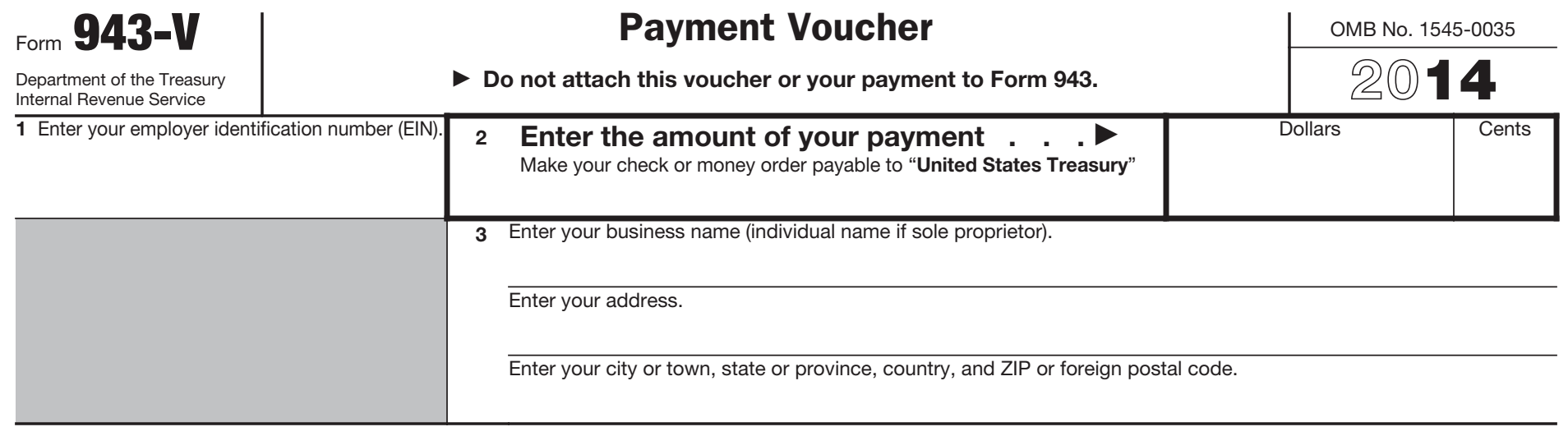




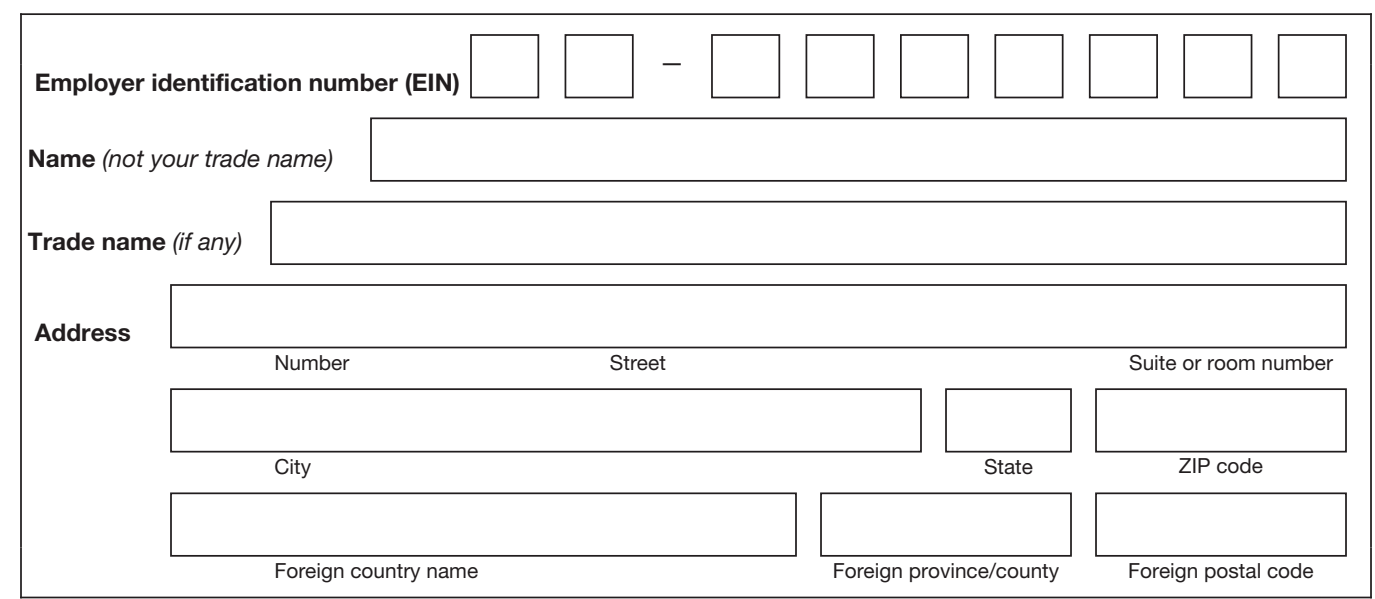

\section{Who Must File Form 944}

You must file annual Form 944 instead of filing quarterly Forms 941 only if the IRS notified you in writing.

Instructions and prior-year forms are available at www.irs.gov/form944.

Read the separate instructions before you complete Form 944. Type or print within the boxes.

Part 1:

Answer these questions for this year. Employers in American Samoa, Guam, the Commonwealth of the Northern Mariana Islands, the U.S. Virgin Islands, and Puerto Rico can skip lines 1 and 2.

1 Wages, tips, and other compensation

1

2

$3 \square$ Check and go to line 5 .

4 Taxable social security and Medicare wages and tips:

Column 1

Column 2

4a Taxable social security wages
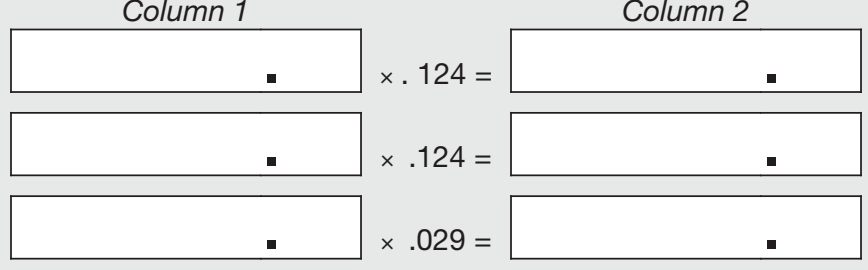

4b Taxable social security tips

4c Taxable Medicare wages \& tips
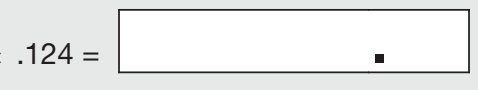

4d Taxable wages \& tips subject

to Additional Medicare Tax withholding

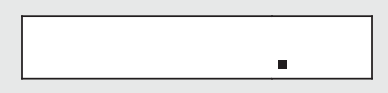

$\times .029=$

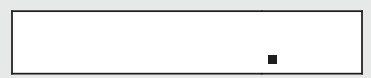

4e Add Column 2 from lines 4a, 4b, 4c, and 4d
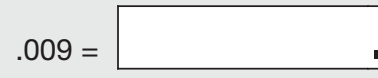

4e Add Column 2 from lines $4 a, 4 b, 4 c$, and $4 d$

5 Total taxes before adjustments. Add lines 2 and $4 \mathrm{e}$

6 Current year's adjustments (see instructions)

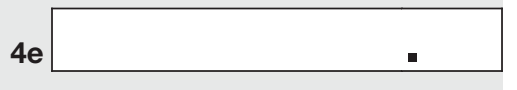

5

6

7

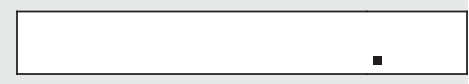

8

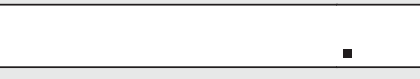
overpayments applied from Form 944-X, 944-X (PR), 944-X (SP), 941-X, or 941-X (PR) .

9a Reserved

9b Reserved

10 Reserved

11 Balance due. If line 7 is more than line 8, enter the difference and see instructions 
Part 2: Tell us about your deposit schedule and tax liability for this year.

13 Check one: $\square$ Line 7 is less than $\$ 2,500$. Go to Part 3.

Line 7 is $\$ 2,500$ or more. Enter your tax liability for each month. If you are a semiweekly depositor or you accumulate $\$ 100,000$ or more of liability on any day during a deposit period, you must complete Form $945-A$ instead of the boxes below.
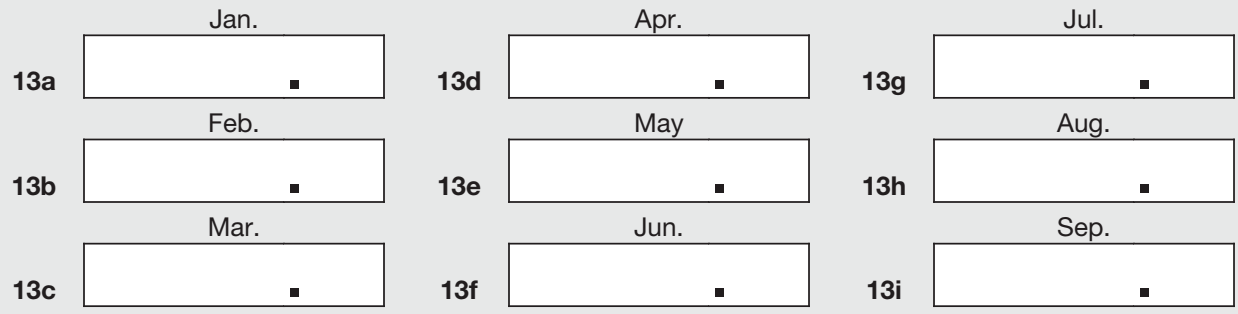

13j

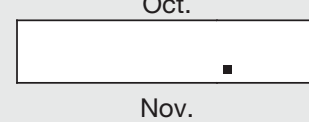

Total liability for year. Add lines 13a through 13I. Total must equal line 7.

$13 \mathrm{~m}$

Part 3: Tell us about your business. If question 14 does NOT apply to your business, leave it blank.

14 If your business has closed or you stopped paying wages...

$\square$ Check here and enter the final date you paid wages.

\section{Part 4: May we speak with your third-party designee?}

Do you want to allow an employee, a paid tax preparer, or another person to discuss this return with the IRS? See the instructions for details.

$\square$ Yes. Designee's name and phone number
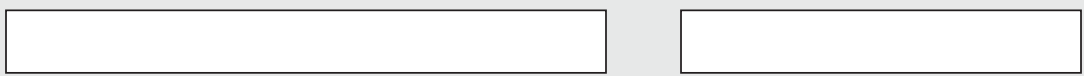

Select a 5-digit Personal Identification Number (PIN) to use when talking to IRS.

$\square$ No.

\section{Part 5: Sign Here. You MUST complete both pages of Form 944 and SIGN it.}

Under penalties of perjury, I declare that I have examined this return, including accompanying schedules and statements, and to the best of my knowledge and belief, it is true, correct, and complete. Declaration of preparer (other than taxpayer) is based on all information of which preparer has any knowledge.

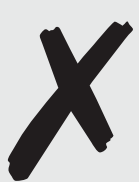

\section{Sign your \\ name here}

Date

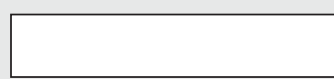

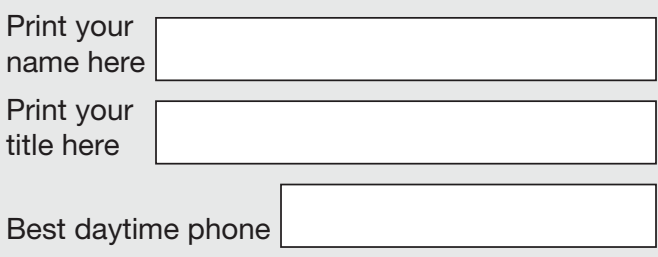

Check if you are self-employed $\square$

\section{Paid Preparer Use Only}

Preparer's name

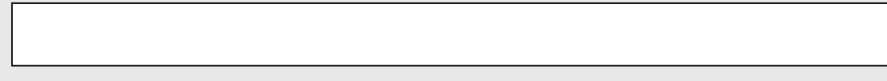

Preparer's signature

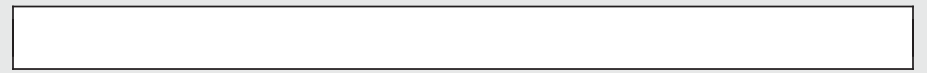

Firm's name (or yours if self-employed)

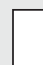

Address

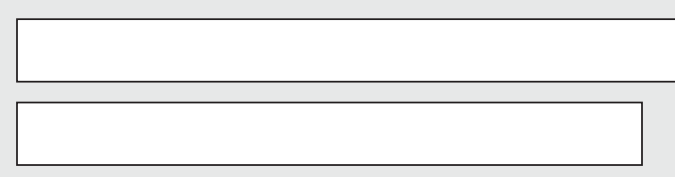

State

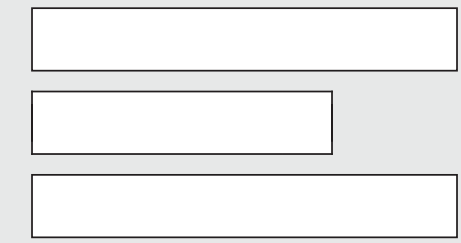

Phone

ZIP code 


\section{Form 944-V, Payment Voucher}

\section{Purpose of Form}

Complete Form 944-V, Payment Voucher, if you are making a payment with Form 944, Employer's ANNUAL Federal Tax Return. We will use the completed voucher to credit your payment more promptly and accurately, and to improve our service to you.

\section{Making Payments With Form 944}

To avoid a penalty, make your payment with your 2014 Form 944 only if one of the following applies.

- Your net taxes for the year (Form 944, line 7) are less than $\$ 2,500$ and you are paying in full with a timely filed return.

- You already deposited the taxes you owed for the first, second, and third quarters of 2014, and the tax you owe for the fourth quarter of 2014 is less than $\$ 2,500$, and you are paying, in full, the tax you owe for the fourth quarter of 2014 with a timely filed return.

- Your net taxes for the third quarter are $\$ 2,500$ or more, net taxes for the fourth quarter are less than $\$ 2,500$, and you did not incur a $\$ 100,000$ next-day deposit obligation during the fourth quarter.

- You are a monthly schedule depositor making a payment in accordance with the Accuracy of Deposits Rule. See section 11 of Pub. 15 (Circular E), Employer's Tax Guide, for details. In this case, the amount of your payment may be $\$ 2,500$ or more.

Otherwise, you must make deposits by electronic funds transfer. See section 11 of Pub. 15 (Circular E) for deposit instructions. Do not use Form $944-\mathrm{V}$ to make federal tax deposits.

Caution. Use Form 944-V when making any payment with Form 944. However, if you pay an amount with Form 944 that should have been deposited, you may be subject to a penalty. See Deposit Penalties in section 11 of Pub. 15 (Circular E).

\section{Specific Instructions}

Box 1-Employer identification number (EIN). If you do not have an EIN, you may apply for one online. Go to IRS.gov and type "EIN" in the search box. You may also apply for an EIN by faxing or mailing Form SS-4, Application for Employer Identification Number, to the IRS. If you have not received your EIN by the due date of Form 944, write "Applied For" and the date you applied in this entry space.

Box 2-Amount paid. Enter the amount paid with Form 944.

Box 3-Name and address. Enter your name and address as shown on Form 944.

- Enclose your check or money order made payable to the "United States Treasury" and write your EIN, "Form 944," and "2014" on your check or money order. Do not send cash. Do not staple Form 944-V or your payment to Form 944 (or to each other).

- Detach Form 944-V and send it with your payment and Form 944 to the address provided in the Instructions for Form 944. Do not send a photocopy of Form 944-V because your payment may be misapplied or delayed.

Note. You must also complete the entity information above Part 1 on Form 944.

\section{Detach Here and Mail With Your Payment and Form 944.}

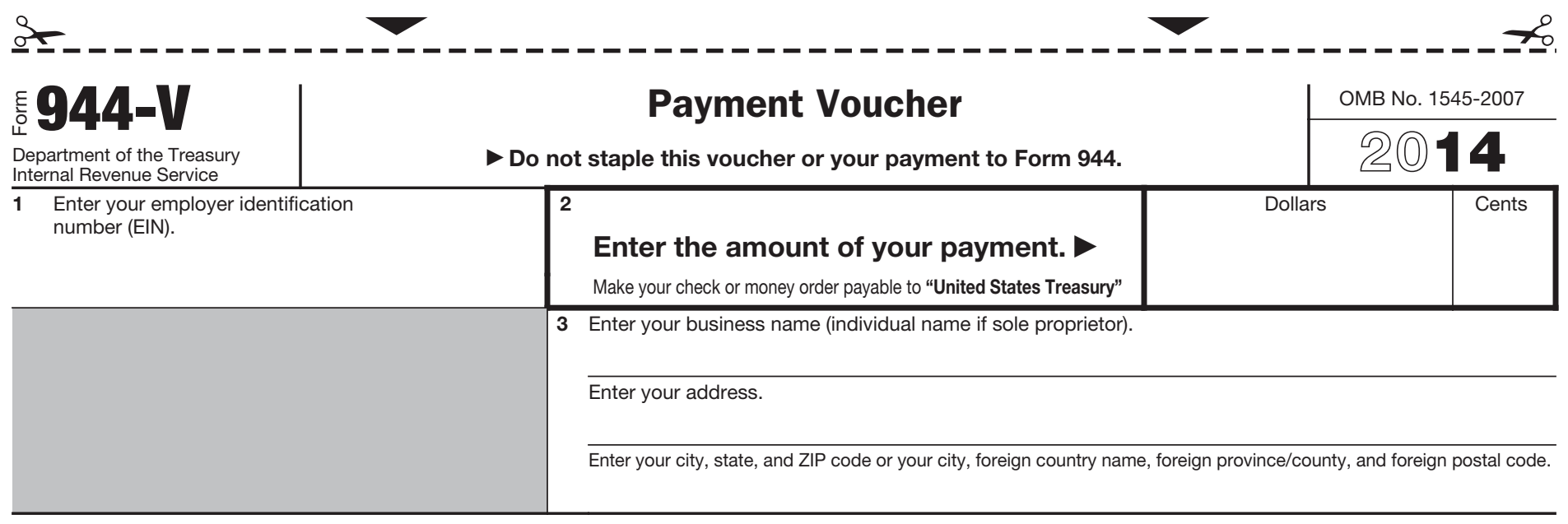


Privacy Act and Paperwork Reduction Act Notice. We ask for the information on this form to carry out the Internal Revenue laws of the United States. We need it to figure and collect the right amount of tax. Subtitle C, Employment Taxes, of the Internal Revenue Code imposes employment taxes on wages and provides for income tax withholding. This form is used to determine the amount of the taxes that you owe. Section 6011 requires you to provide the requested information if the tax is applicable to you. Section 6109 requires you to provide your identification number. If you fail to provide this information in a timely manner, or provide false or fraudulent information, you may be subject to penalties.

You are not required to provide the information requested on a form that is subject to the Paperwork Reduction Act unless the form displays a valid OMB control number. Books and records relating to a form or instructions must be retained as long as their contents may become material in the administration of any Internal Revenue law.

Generally, tax returns and return information are confidential, as required by section 6103 . However, section 6103 allows or requires the IRS to disclose or give the information shown on your tax return to others as described in the Code. For example, we may disclose your tax information to the Department of Justice for civil and criminal litigation, and to cities, states, the District of Columbia, and U.S. commonwealths and possessions for use in administering their tax laws. We may also disclose this information to other countries under a tax treaty, to federal and state agencies to enforce federal nontax criminal laws, or to federal law enforcement and intelligence agencies to combat terrorism.

The time needed to complete and file Form 944 will vary depending on individual circumstances. The estimated average time is:

Recordkeeping . . . . . . . . . . $13 \mathrm{hr} ., 9 \mathrm{~min}$. Learning about the law or the form . . . . $40 \mathrm{~min}$. Preparing, copying, assembling, and sending the form to the IRS . . . . . . $2 \mathrm{hr} ., 6 \mathrm{~min}$.

If you have comments concerning the accuracy of these time estimates or suggestions for making Form 944 simpler, we would be happy to hear from you. You can send us comments from www.irs.gov/formspubs. Click on More Information and then click on Give us feedback. Or you can send your comments to Internal Revenue Service, Tax Forms and Publications Division, 1111 Constitution Ave. NW, IR-6526, Washington, DC 20224. Do not send Form 944 to this address. Instead see Where Should You File? in the Instructions for Form 944. 
B Check if applicable: C Name of organization

Open to Public Inspection

$\square$ Address change $\quad$ Doing business as

$\square$ Name change

$\square$ Initial return

$\square$ Final return/terminated

$\square$ Amended return

$\square$ Application pending $\mathbf{F}$ Name and address of principal officer:

City or town, state or province, country, and ZIP or foreign postal code

Room/suite

D Employer identification number

E Telephone number

G Gross receipts \$

I Tax-exempt status: $\square$ 501(c)(3) $\quad \square$ 501(c)( $) 4$ (insert no.) $\square$ 4947(a)(1) or $\square 527$ group return for subordinates? $\square$ Yes $\square$ No H(b) Are all subordinates included? $\square$ Yes $\square$ No If "No," attach a list. (see instructions)

J Website: $>$

K Form of organization: $\square$ Corporation $\square$ Trust $\square$ Association $\square$ Other H(c) Group exemption number

\section{Part I Summary}

1 Briefly describe the organization's mission or most significant activities:

2 Check this box $\square$ if the organization discontinued its operations or disposed of more than $25 \%$ of its net assets

3 Number of voting members of the governing body (Part VI, line 1a).

4 Number of independent voting members of the governing body (Part VI, line 1b)

5 Total number of individuals employed in calendar year 2014 (Part V, line 2a)

6 Total number of volunteers (estimate if necessary)

7a Total unrelated business revenue from Part VIII, column (C), line 12

b Net unrelated business taxable income from Form 990-T, line 34

8 Contributions and grants (Part VIII, line 1h)

ฯ

9 Program service revenue (Part VIII, line $2 \mathrm{~g}$ )

10 Investment income (Part VIII, column (A), lines 3, 4, and 7d)

11 Other revenue (Part VIII, column (A), lines 5, 6d, 8c, 9c, 10c, and 11e)

12 Total revenue-add lines 8 through 11 (must equal Part VIII, column (A), line 12)

13 Grants and similar amounts paid (Part IX, column (A), lines 1-3) .

14 Benefits paid to or for members (Part IX, column (A), line 4)

mployee benefits (Part IX, colum

a Professional fundraising fees (Part IX, column (A), line 11e)

b Total fundraising expenses (Part IX, column (D), line 25)

17 Other expenses (Part IX, column (A), lines 11a-11d, 11f-24e)

18 Total expenses. Add lines 13-17 (must equal Part IX, column (A), line 25)

19 Revenue less expenses. Subtract line 18 from line 12

20 Total assets (Part $X$, line 16)

21 Total liabilities (Part X, line 26)

22 Net assets or fund balances. Subtract line 21 from line 20

\section{Part II Signature Block}

Under penalties of perjury, I declare that I have examined this return, including accompanying schedules and statements, and to the best of my knowledge and belief, it is true, correct, and complete. Declaration of preparer (other than officer) is based on all information of which preparer has any knowledge.

\begin{tabular}{|c|c|c|c|c|c|}
\hline \multirow{2}{*}{$\begin{array}{l}\text { Sign } \\
\text { Here }\end{array}$} & \multicolumn{2}{|l|}{ Signature of officer } & & \multicolumn{2}{|l|}{ Date } \\
\hline & \multicolumn{5}{|c|}{ Type or print name and title } \\
\hline \multirow{3}{*}{$\begin{array}{l}\text { Paid } \\
\text { Preparer } \\
\text { Use Only }\end{array}$} & Print/Type preparer's name & Preparer's signature & Date & $\begin{array}{l}\text { Check } \square \text { if } \\
\text { self-employed }\end{array}$ & \\
\hline & \multicolumn{3}{|l|}{ Firm's name } & \multicolumn{2}{|l|}{ Firm's EIN } \\
\hline & \multicolumn{3}{|l|}{ Firm's address } & \multicolumn{2}{|l|}{ Phone no. } \\
\hline
\end{tabular}

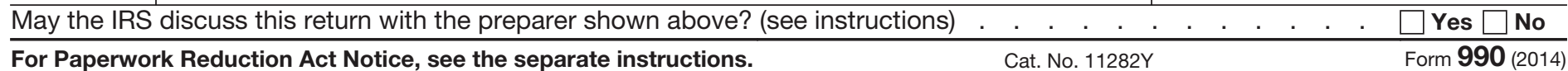




\section{Part IX Statement of Functional Expenses}

Section 501(c)(3) and 501(c)(4) organizations must complete all columns. All other organizations must complete column (A).

Check if Schedule O contains a response or note to any line in this Part IX

Do not include amounts reported on lines $6 b, 7 b$, $8 b, 9 b$, and $10 b$ of Part VIII.

1 Grants and other assistance to domestic organizations and domestic governments. See Part IV, line 21

2 Grants and other assistance to domestic individuals. See Part IV, line 22 . . . . . . .

3 Grants and other assistance to foreign organizations, foreign governments, and foreign individuals. See Part IV, lines 15 and 16 .

4 Benefits paid to or for members

5 Compensation of current officers, directors, trustees, and key employees

6 Compensation not included above, to disqualified persons (as defined under section 4958(f)(1)) and persons described in section 4958(C)(3)(B)

7 Other salaries and wages

8 Pension plan accruals and contributions (include section 401(k) and 403(b) employer contributions)

9 Other employee benefits

10 Payroll taxes.

11 Fees for services (non-employees):

a Management

b Legal

d Lobbying . . . . . . . . . . . . .

e Professional fundraising services. See Part IV, line 17

f Investment management fees . . . . .

g Other. (If line $11 \mathrm{~g}$ amount exceeds $10 \%$ of line 25 , column (A) amount, list line $11 \mathrm{~g}$ expenses on Schedule 0.)

Advertising and promotion

13 Office expenses

14 Information technology

15 Royalties.

16 Occupancy

17 Travel.

18 Payments of travel or entertainment expenses for any federal, state, or local public officials

19 Conferences, conventions, and meetings

20 Interest . . . . . . . . . . . .

21 Payments to affiliates . . . . . . . .

22 Depreciation, depletion, and amortization

Insurance . . . . . . . . . . .

24 Other expenses. Itemize expenses not covered above (List miscellaneous expenses in line 24e. If line $24 \mathrm{e}$ amount exceeds $10 \%$ of line 25 , column (A) amount, list line $24 \mathrm{e}$ expenses on Schedule O.)

a

b

C

d

e All other expenses

25 Total functional expenses. Add lines 1 through $24 \mathrm{e}$

26 Joint costs. Complete this line only if the organization reported in column (B) joint costs from a combined educational campaign and fundraising solicitation. Check here following SOP 98-2 (ASC 958-720)

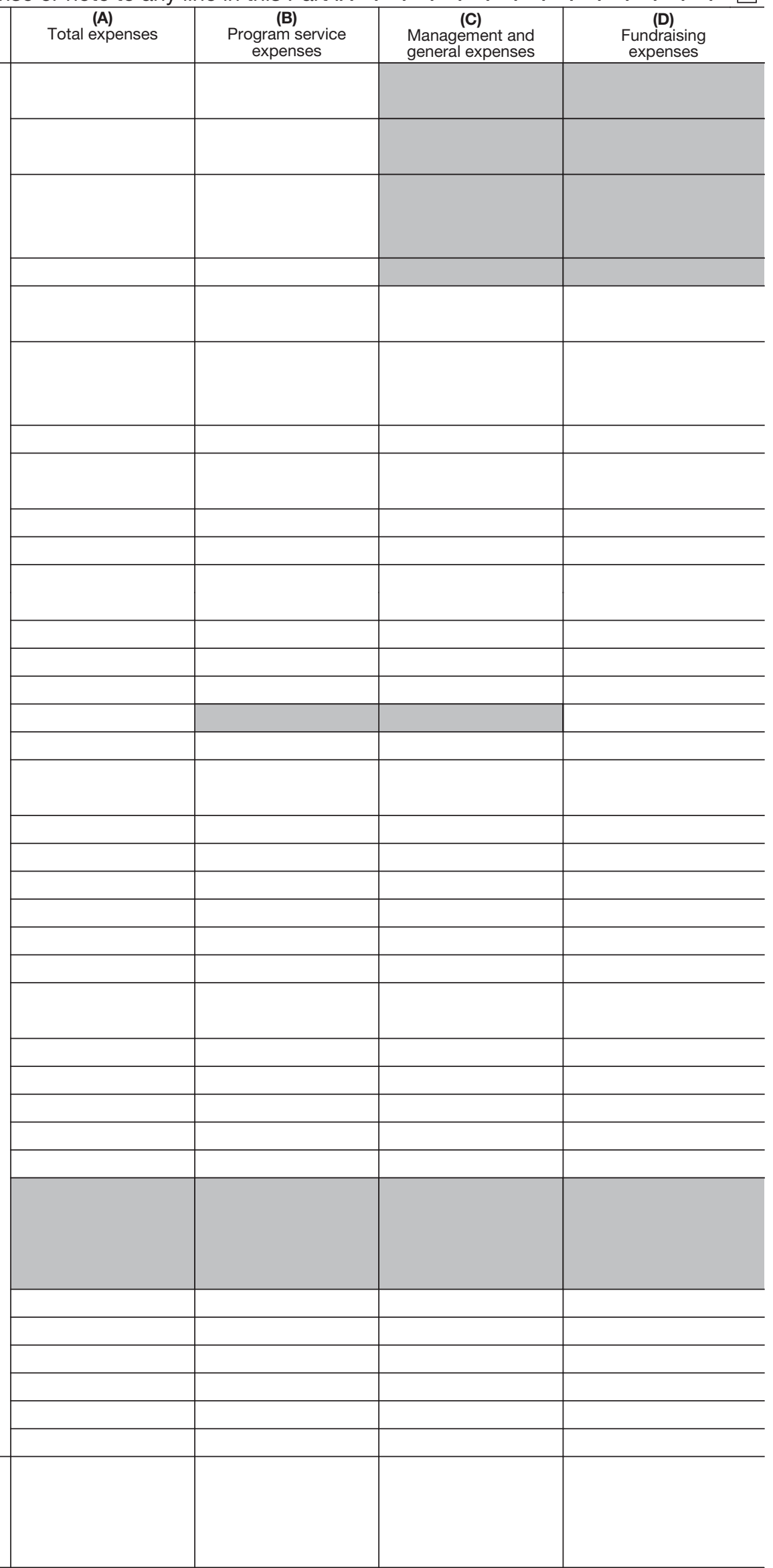


1 Cash-non-interest-bearing

2 Savings and temporary cash investments

3 Pledges and grants receivable, net

4 Accounts receivable, net

5 Loans and other receivables from current and former officers, directors, trustees, key employees, and highest compensated employees. Complete Part II of Schedule L

6 Loans and other receivables from other disqualified persons (as defined under section 4958(f)(1)), persons described in section 4958(C)(3)(B), and contributing employers and sponsoring organizations of section 501(c)(9) voluntary employees' beneficiary organizations (see instructions). Complete Part II of Schedule L

7 Notes and loans receivable, net

8 Inventories for sale or use

9 Prepaid expenses and deferred charges

10a Land, buildings, and equipment: cost or other basis. Complete Part VI of Schedule D

b Less: accumulated depreciation . . . .

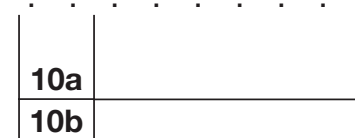

11 Investments - publicly traded securities

12 Investments-other securities. See Part IV, line 11

13 Investments-program-related. See Part IV, line 11

14 Intangible assets

15 Other assets. See Part IV, line 11.

16 Total assets. Add lines 1 through 15 (must equal line 34).

17 Accounts payable and accrued expenses

18 Grants payable .

19 Deferred revenue

20 Tax-exempt bond liabilities

Escrow or custodial account liability. Complete Part IV of Schedule D .

2 Loans and other payables to current and former officers, directors, trustees, key employees, highest compensated employees, and disqualified persons. Complete Part II of Schedule L

23 Secured mortgages and notes payable to unrelated third parties

24 Unsecured notes and loans payable to unrelated third parties

25 Other liabilities (including federal income tax, payables to related third parties, and other liabilities not included on lines 17-24). Complete Part X of Schedule D

26 Total liabilities. Add lines 17 through 25

Organizations that follow SFAS 117 (ASC 958), check here $\square$ and complete lines 27 through 29, and lines 33 and 34 .

27 Unrestricted net assets

28 Temporarily restricted net assets

29 Permanently restricted net assets.

Organizations that do not follow SFAS 117 (ASC 958), check here complete lines 30 through 34 .

\begin{tabular}{|c|c|c|}
\hline \multirow[t]{6}{*}{$\begin{array}{c}\text { (A) } \\
\text { Beginning of year }\end{array}$} & & $\begin{array}{c}\text { (B) } \\
\text { End of year }\end{array}$ \\
\hline & 1 & \\
\hline & 2 & \\
\hline & 3 & \\
\hline & 4 & \\
\hline & 5 & \\
\hline & 6 & \\
\hline & 7 & \\
\hline & 8 & \\
\hline & 9 & \\
\hline & 10c & \\
\hline & 11 & \\
\hline & 12 & \\
\hline & 13 & \\
\hline & 14 & \\
\hline & 15 & \\
\hline & 16 & \\
\hline & 17 & \\
\hline & 18 & \\
\hline & 19 & \\
\hline & 20 & \\
\hline & 21 & \\
\hline & 22 & \\
\hline & 23 & \\
\hline & 24 & \\
\hline & 25 & \\
\hline & 26 & \\
\hline & 27 & \\
\hline & 28 & \\
\hline & 29 & \\
\hline & 30 & \\
\hline & 31 & \\
\hline & 32 & \\
\hline & 33 & \\
\hline & 34 & \\
\hline
\end{tabular}




\section{Part XI Reconciliation of Net Assets}

Check if Schedule O contains a response or note to any line in this Part X

1 Total revenue (must equal Part VIII, column (A), line 12)

2 Total expenses (must equal Part IX, column (A), line 25)

3 Revenue less expenses. Subtract line 2 from line 1

Net assets or fund balances at beginning of year (must equal Part X, line 33, column (A)) . .

5 Net unrealized gains (losses) on investments . . . . . . . . . . . . . . . . . . . . . . .

6 Donated services and use of facilities

7 Investment expenses.

8 Prior period adjustments

9 Other changes in net assets or fund balances (explain in Schedule O) . . . . . . . . . . . .

10 Net assets or fund balances at end of year. Combine lines 3 through 9 (must equal Part $X$, line 33, column (B))

\section{Part XII Financial Statements and Reporting}

Check if Schedule O contains a response or note to any line in this Part XII

1 Accounting method used to prepare the Form 990: $\square$ Cash $\square$ Accrual $\quad \square$ Other

If the organization changed its method of accounting from a prior year or checked "Other," explain in Schedule O.

2a Were the organization's financial statements compiled or reviewed by an independent accountant? . . . If "Yes," check a box below to indicate whether the financial statements for the year were compiled or reviewed on a separate basis, consolidated basis, or both:

$\square$ Separate basis $\square$ Consolidated basis $\square$ Both consolidated and separate basis

b Were the organization's financial statements audited by an independent accountant?

If "Yes," check a box below to indicate whether the financial statements for the year were audited on a separate basis, consolidated basis, or both:

$\square$ Separate basis $\square$ Consolidated basis $\square$ Both consolidated and separate basis

c If "Yes" to line $2 \mathrm{a}$ or $2 \mathrm{~b}$, does the organization have a committee that assumes responsibility for oversight of the audit, review, or compilation of its financial statements and selection of an independent accountant?

If the organization changed either its oversight process or selection process during the tax year, explain in Schedule O.

3a As a result of a federal award, was the organization required to undergo an audit or audits as set forth in the Single Audit Act and OMB Circular A-133? .

b If "Yes," did the organization undergo the required audit or audits? If the organization did not undergo the required audit or audits, explain why in Schedule $\mathrm{O}$ and describe any steps taken to undergo such audits.

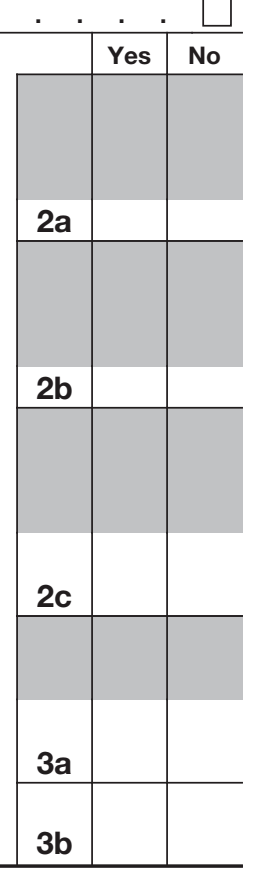




\section{Part III Statement of Program Service Accomplishments}

Check if Schedule O contains a response or note to any line in this Part III

1 Briefly describe the organization's mission:

2 Did the organization undertake any significant program services during the year which were not listed on the prior Form 990 or $990-E Z$ ?

If "Yes," describe these new services on Schedule O.

3 Did the organization cease conducting, or make significant changes in how it conducts, any program services?

If "Yes," describe these changes on Schedule O.

4 Describe the organization's program service accomplishments for each of its three largest program services, as measured by expenses. Section 501 (c)(3) and 501(c)(4) organizations are required to report the amount of grants and allocations to others, the total expenses, and revenue, if any, for each program service reported.

4a (Code: _. $)$ (Expenses \$ including grants of \$ _...) (Revenue \$

4b (Code: $\quad$ ) (Expenses $\$ \quad$ including grants of $\$$ Revenue $\$$

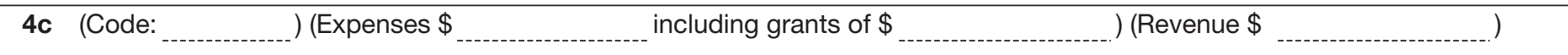

4d Other program services (Describe in Schedule O.) (Expenses \$ including grants of \$

) (Revenue \$ )


1 Is the organization described in section 501(c)(3) or 4947(a)(1) (other than a private foundation)? If "Yes," complete Schedule A.

2 Is the organization required to complete Schedule B, Schedule of Contributors (see instructions)?

3 Did the organization engage in direct or indirect political campaign activities on behalf of or in opposition to candidates for public office? If "Yes," complete Schedule C, Part I .

4 Section $501(\mathrm{c})(3)$ organizations. Did the organization engage in lobbying activities, or have a section $501(\mathrm{~h})$ election in effect during the tax year? If "Yes," complete Schedule C, Part II .

5 Is the organization a section 501(c)(4), 501(c)(5), or 501(c)(6) organization that receives membership dues, assessments, or similar amounts as defined in Revenue Procedure 98-19? If "Yes," complete Schedule C, Part III

6 Did the organization maintain any donor advised funds or any similar funds or accounts for which donors have the right to provide advice on the distribution or investment of amounts in such funds or accounts? If "Yes," complete Schedule D, Part I

7 Did the organization receive or hold a conservation easement, including easements to preserve open space, the environment, historic land areas, or historic structures? If "Yes," complete Schedule D, Part II

8 Did the organization maintain collections of works of art, historical treasures, or other similar assets? If "Yes," complete Schedule D, Part III

9 Did the organization report an amount in Part X, line 21, for escrow or custodial account liability; serve as a custodian for amounts not listed in Part X; or provide credit counseling, debt management, credit repair, or debt negotiation services? If "Yes," complete Schedule D, Part IV .

10 Did the organization, directly or through a related organization, hold assets in temporarily restricted endowments, permanent endowments, or quasi-endowments? If "Yes," complete Schedule D, Part V

11 If the organization's answer to any of the following questions is "Yes," then complete Schedule D, Parts VI, VII, VIII, IX, or X as applicable.

a Did the organization report an amount for land, buildings, and equipment in Part X, line 10? If "Yes," complete Schedule D, Part VI

b Did the organization report an amount for investments-other securities in Part X, line 12 that is $5 \%$ or more of its total assets reported in Part X, line 16? If "Yes," complete Schedule D, Part VII

c Did the organization report an amount for investments-program related in Part X, line 13 that is $5 \%$ or more of its total assets reported in Part X, line 16? If "Yes," complete Schedule D, Part VIII

d Did the organization report an amount for other assets in Part X, line 15 that is $5 \%$ or more of its total assets reported in Part X, line 16? If "Yes," complete Schedule D, Part IX .

e Did the organization report an amount for other liabilities in Part X, line 25? If "Yes," complete Schedule D, Part X

$f$ Did the organization's separate or consolidated financial statements for the tax year include a footnote that addresses the organization's liability for uncertain tax positions under FIN 48 (ASC 740)? If "Yes," complete Schedule D, Part X .

12 a Did the organization obtain separate, independent audited financial statements for the tax year? If "Yes," complete Schedule D, Parts XI and XII

b Was the organization included in consolidated, independent audited financial statements for the tax year? If "Yes," and if the organization answered "No" to line 12a, then completing Schedule D, Parts XI and XII is optional .

13 Is the organization a school described in section 170(b)(1)(A)(ii)? If "Yes," complete Schedule $E$

14 a Did the organization maintain an office, employees, or agents outside of the United States?

b Did the organization have aggregate revenues or expenses of more than $\$ 10,000$ from grantmaking, fundraising, business, investment, and program service activities outside the United States, or aggregate foreign investments valued at $\$ 100,000$ or more? If "Yes," complete Schedule F, Parts I and IV.

15 Did the organization report on Part IX, column (A), line 3, more than $\$ 5,000$ of grants or other assistance to or for any foreign organization? If "Yes," complete Schedule F, Parts II and IV

16 Did the organization report on Part IX, column (A), line 3, more than $\$ 5,000$ of aggregate grants or other assistance to or for foreign individuals? If "Yes," complete Schedule F, Parts III and IV.

17 Did the organization report a total of more than $\$ 15,000$ of expenses for professional fundraising services on Part IX, column (A), lines 6 and 11e? If "Yes," complete Schedule G, Part I (see instructions)

18 Did the organization report more than $\$ 15,000$ total of fundraising event gross income and contributions on Part VIII, lines 1c and 8a? If "Yes," complete Schedule G, Part II .

19 Did the organization report more than $\$ 15,000$ of gross income from gaming activities on Part VIII, line 9a? If "Yes," complete Schedule G, Part III

20 a Did the organization operate one or more hospital facilities? If "Yes," complete Schedule $H$.

b If "Yes" to line $20 \mathrm{a}$, did the organization attach a copy of its audited financial statements to this return?

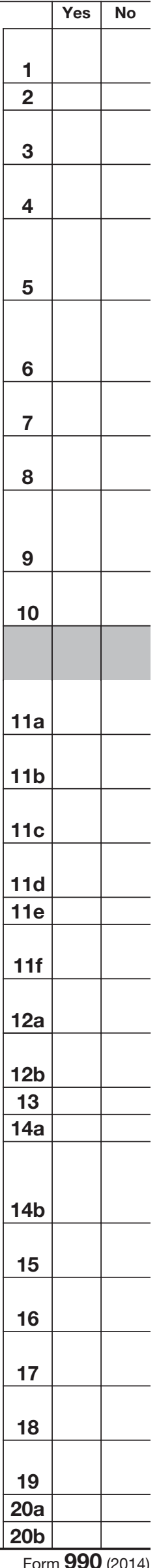


21 Did the organization report more than $\$ 5,000$ of grants or other assistance to any domestic organization or domestic government on Part IX, column (A), line 1? If "Yes," complete Schedule I, Parts I and II .

Did the organization report more than $\$ 5,000$ of grants or other assistance to or for domestic individuals on Part IX, column (A), line 2? If "Yes," complete Schedule I, Parts I and III

Did the organization answer "Yes" to Part VII, Section A, line 3, 4, or 5 about compensation of the organization's current and former officers, directors, trustees, key employees, and highest compensated employees? If "Yes," complete Schedule J .

24a Did the organization have a tax-exempt bond issue with an outstanding principal amount of more than $\$ 100,000$ as of the last day of the year, that was issued after December 31, 2002? If "Yes," answer lines 24b through $24 d$ and complete Schedule K. If "No," go to line $25 a$

b Did the organization invest any proceeds of tax-exempt bonds beyond a temporary period exception? .

c Did the organization maintain an escrow account other than a refunding escrow at any time during the year to defease any tax-exempt bonds?

d Did the organization act as an "on behalf of" issuer for bonds outstanding at any time during the year? .

25a Section 501(c)(3), 501(c)(4), and 501(c)(29) organizations. Did the organization engage in an excess benefit transaction with a disqualified person during the year? If "Yes," complete Schedule L, Part I

b Is the organization aware that it engaged in an excess benefit transaction with a disqualified person in a prior year, and that the transaction has not been reported on any of the organization's prior Forms 990 or $990-\mathrm{EZ}$ ? If "Yes," complete Schedule L, Part I .

26 Did the organization report any amount on Part X, line 5, 6, or 22 for receivables from or payables to any current or former officers, directors, trustees, key employees, highest compensated employees, or disqualified persons? If "Yes, " complete Schedule L, Part II

27 Did the organization provide a grant or other assistance to an officer, director, trustee, key employee, substantial contributor or employee thereof, a grant selection committee member, or to a $35 \%$ controlled entity or family member of any of these persons? If "Yes," complete Schedule L, Part III .

28 Was the organization a party to a business transaction with one of the following parties (see Schedule L, Part IV instructions for applicable filing thresholds, conditions, and exceptions):

a A current or former officer, director, trustee, or key employee? If "Yes," complete Schedule L, Part IV

b A family member of a current or former officer, director, trustee, or key employee? If "Yes," complete Schedule L, Part IV

c An entity of which a current or former officer, director, trustee, or key employee (or a family member thereof) was an officer, director, trustee, or direct or indirect owner? If "Yes," complete Schedule L, Part IV . Did the organization receive more than $\$ 25,000$ in non-cash contributions? If "Yes," complete Schedule $M$

30 Did the organization receive contributions of art, historical treasures, or other similar assets, or qualified conservation contributions? If "Yes," complete Schedule M

31 Did the organization liquidate, terminate, or dissolve and cease operations? If "Yes," complete Schedule N, Part I

Did the organization sell, exchange, dispose of, or transfer more than $25 \%$ of its net assets? If "Yes," complete Schedule N, Part II

33 Did the organization own $100 \%$ of an entity disregarded as separate from the organization under Regulations sections 301.7701-2 and 301.7701-3? If "Yes," complete Schedule R, Part I .

34 Was the organization related to any tax-exempt or taxable entity? If "Yes," complete Schedule R, Part II, III, or IV, and Part $V$, line 1

35a Did the organization have a controlled entity within the meaning of section 512(b)(13)?

b If "Yes" to line $35 \mathrm{a}$, did the organization receive any payment from or engage in any transaction with a controlled entity within the meaning of section 512(b)(13)? If "Yes," complete Schedule R, Part V, line 2 .

36 Section 501(c)(3) organizations. Did the organization make any transfers to an exempt non-charitable related organization? If "Yes," complete Schedule R, Part V, line 2 .

37 Did the organization conduct more than $5 \%$ of its activities through an entity that is not a related organization and that is treated as a partnership for federal income tax purposes? If "Yes," complete Schedule $R$,

Part VI .

38 Did the organization complete Schedule O and provide explanations in Schedule O for Part VI, lines 11b and 19 ? Note. All Form 990 filers are required to complete Schedule O .

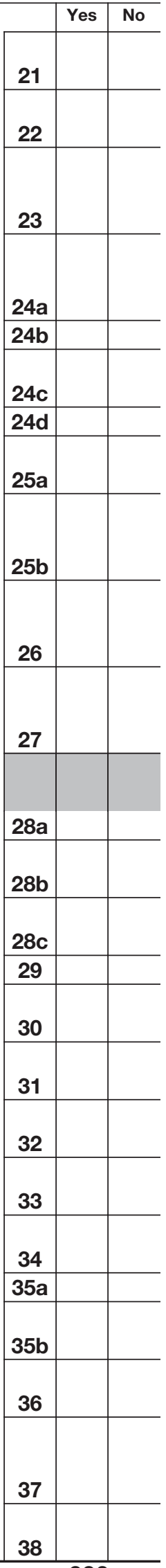

Form $990(2014)$ 
1a Enter the number reported in Box 3 of Form 1096. Enter -0- if not applicable

b Enter the number of Forms W-2G included in line 1a. Enter -0- if not applicable .

c Did the organization comply with backup withholding rules for reportable payments to vendors and reportable gaming (gambling) winnings to prize winners?

2a Enter the number of employees reported on Form W-3, Transmittal of Wage and Tax Statements, filed for the calendar year ending with or within the year covered by this return

\section{$2 a$}

b If at least one is reported on line $2 a$, did the organization file all required federal employment tax returns? Note. If the sum of lines $1 \mathrm{a}$ and $2 \mathrm{a}$ is greater than 250 , you may be required to e-file (see instructions) . .

3a Did the organization have unrelated business gross income of $\$ 1,000$ or more during the year?

b If "Yes," has it filed a Form 990-T for this year? If "No" to line 3b, provide an explanation in Schedule O .

4a At any time during the calendar year, did the organization have an interest in, or a signature or other authority over, a financial account in a foreign country (such as a bank account, securities account, or other financial account)?

b If "Yes," enter the name of the foreign country:

See instructions for filing requirements for FinCEN Form 114, Report of Foreign Bank and Financial Accounts (FBAR).

5a Was the organization a party to a prohibited tax shelter transaction at any time during the tax year?

b

c If "Yes" to line $5 \mathrm{a}$ or $5 \mathrm{~b}$, did the organization file Form 8886-T?

$6 a$ Does the organization have annual gross receipts that are normally greater than $\$ 100,000$, and did the organization solicit any contributions that were not tax deductible as charitable contributions? .

b If "Yes," did the organization include with every solicitation an express statement that such contributions or gifts were not tax deductible?

7 Organizations that may receive deductible contributions under section 170(c).

a Did the organization receive a payment in excess of $\$ 75$ made partly as a contribution and partly for goods and services provided to the payor?

b If "Yes," did the organization notify the donor of the value of the goods or services provided?

c Did the organization sell, exchange, or otherwise dispose of tangible personal property for which it was required to file Form 8282 ?

d If "Yes," indicate the number of Forms 8282 filed during the year

\section{7d}

e Did the organization receive any funds, directly or indirectly, to pay premiums on a personal benefit contract?

f Did the organization, during the year, pay premiums, directly or indirectly, on a personal benefit contract? .

g If the organization received a contribution of qualified intellectual property, did the organization file Form 8899 as required?

h If the organization received a contribution of cars, boats, airplanes, or other vehicles, did the organization file a Form 1098-C?

8 Sponsoring organizations maintaining donor advised funds. Did a donor advised fund maintained by the sponsoring organization have excess business holdings at any time during the year?

9 Sponsoring organizations maintaining donor advised funds.

a Did the sponsoring organization make any taxable distributions under section 4966 ?

b Did the sponsoring organization make a distribution to a donor, donor advisor, or related person?

10 Section 501(c)(7) organizations. Enter:

a Initiation fees and capital contributions included on Part VIII, line 12

b Gross receipts, included on Form 990, Part VIII, line 12, for public use of club facilities

11 Section 501(c)(12) organizations. Enter:

a Gross income from members or shareholders.

b Gross income from other sources (Do not net amounts due or paid to other sources against amounts due or received from them.)

b If "Yes," enter the amount of tax-exempt interest received or accrued during the year.

13 Section 501(c)(29) qualified nonprofit health insurance issuers.

a Is the organization licensed to issue qualified health plans in more than one state? Note. See the instructions for additional information the organization must report on Schedule O.

b Enter the amount of reserves the organization is required to maintain by the states in which the organization is licensed to issue qualified health plans

c Enter the amount of reserves on hand

14a Did the organization receive any payments for indoor tanning services during the tax year? .

b If "Yes," has it filed a Form 720 to report these payments? If "No, " provide an explanation in Schedule O 10a

$10 \mathrm{~b}$

\begin{tabular}{|c|}
$11 a$ \\
$11 b$ \\
\hline
\end{tabular}

$12 b$
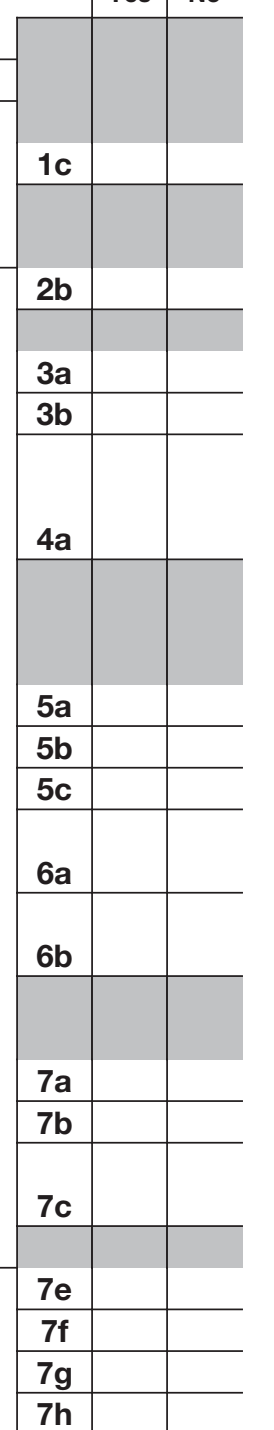

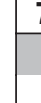

8
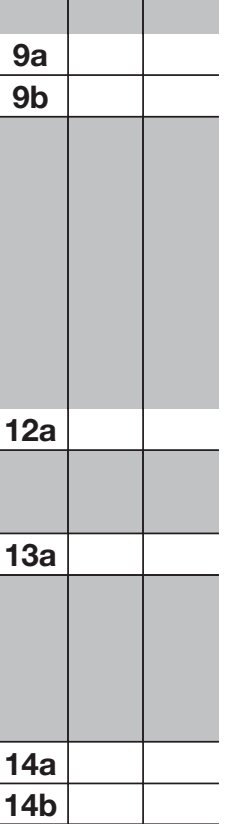

Form 990 (2014) 
Part VI Governance, Management, and Disclosure For each "Yes" response to lines 2 through $7 \mathrm{~b}$ below, and for a "No" response to line 8a, 8b, or $10 \mathrm{~b}$ below, describe the circumstances, processes, or changes in Schedule O. See instructions. Check if Schedule O contains a response or note to any line in this Part VI

\section{Section A. Governing Body and Management}

1a Enter the number of voting members of the governing body at the end of the tax year. If there are material differences in voting rights among members of the governing body, or if the governing body delegated broad authority to an executive committee or similar committee, explain in Schedule O.

b Enter the number of voting members included in line 1a, above, who are independent

$\mid \begin{aligned} & 1 \\ & 1\end{aligned}$

2 Did any officer, director, trustee, or key employee have a family relationship or a business relationship with any other officer, director, trustee, or key employee?

3 Did the organization delegate control over management duties customarily performed by or under the direct supervision of officers, directors, or trustees, or key employees to a management company or other person?

4 Did the organization make any significant changes to its governing documents since the prior Form 990 was filed?

5 Did the organization become aware during the year of a significant diversion of the organization's assets? .

6 Did the organization have members or stockholders?

7a Did the organization have members, stockholders, or other persons who had the power to elect or appoint one or more members of the governing body?

b Are any governance decisions of the organization reserved to (or subject to approval by) members, stockholders, or persons other than the governing body?

8 Did the organization contemporaneously document the meetings held or written actions undertaken during the year by the following:

a The governing body?

b Each committee with authority to act on behalf of the governing body?

9 Is there any officer, director, trustee, or key employee listed in Part VII, Section A, who cannot be reached at the organization's mailing address? If "Yes," provide the names and addresses in Schedule $O$.

Section B. Policies (This Section B requests information about policies not required by the Internal Revenue Code.)

10a Did the organization have local chapters, branches, or affiliates?

b If "Yes," did the organization have written policies and procedures governing the activities of such chapters, affiliates, and branches to ensure their operations are consistent with the organization's exempt purposes?

11a Has the organization provided a complete copy of this Form 990 to all members of its governing body before filing the form?

b Describe in Schedule $O$ the process, if any, used by the organization to review this Form 990.

12a Did the organization have a written conflict of interest policy? If "No," go to line 13

b Were officers, directors, or trustees, and key employees required to disclose annually interests that could give rise to conflicts?

c Did the organization regularly and consistently monitor and enforce compliance with the policy? If "Yes," describe in Schedule O how this was done.

13 Did the organization have a written whistleblower policy? . . . . . . . . . . . . . . . . . . . . . . .

14 Did the organization have a written document retention and destruction policy?

15 Did the process for determining compensation of the following persons include a review and approval by independent persons, comparability data, and contemporaneous substantiation of the deliberation and decision?

a The organization's CEO, Executive Director, or top management official

b Other officers or key employees of the organization. If "Yes" to line $15 \mathrm{a}$ or $15 \mathrm{~b}$, describe the process in Schedule O (see instructions).

16a Did the organization invest in, contribute assets to, or participate in a joint venture or similar arrangement with a taxable entity during the year?

b If "Yes," did the organization follow a written policy or procedure requiring the organization to evaluate its participation in joint venture arrangements under applicable federal tax law, and take steps to safeguard the organization's exempt status with respect to such arrangements?

\begin{tabular}{|l|l|l}
\multicolumn{1}{l|}{} & Yes & No \\
\hline $10 \mathrm{a}$ & & \\
\hline $10 \mathrm{~b}$ & & \\
\hline $11 \mathrm{a}$ & & \\
\hline $12 \mathrm{a}$ & & \\
\hline $12 \mathrm{~b}$ & & \\
\hline $12 \mathrm{c}$ & & \\
\hline 13 & & \\
\hline 14 & & \\
\hline & & \\
\hline $15 \mathrm{a}$ & & \\
\hline $15 \mathrm{~b}$ & & \\
\hline & & \\
\hline $16 \mathrm{a}$ & & \\
\hline & & \\
\hline $16 \mathrm{~b}$ & & \\
\hline
\end{tabular}

\section{Section C. Disclosure}

17 List the states with which a copy of this Form 990 is required to be filed

18 Section 6104 requires an organization to make its Forms 1023 (or 1024 if applicable), 990, and 990-T (Section 501(c)(3)s only) available for public inspection. Indicate how you made these available. Check all that apply.

$\square$ Own website $\quad \square$ Another's website $\quad \square$ Upon request $\quad \square$ Other (explain in Schedule O)

19 Describe in Schedule O whether (and if so, how) the organization made its governing documents, conflict of interest policy, and financial statements available to the public during the tax year.

20 State the name, address, and telephone number of the person who possesses the organization's books and records: 
Part VII Compensation of Officers, Directors, Trustees, Key Employees, Highest Compensated Employees, and Independent Contractors

Check if Schedule O contains a response or note to any line in this Part VII

\section{Section A. Officers, Directors, Trustees, Key Employees, and Highest Compensated Employees}

1a Complete this table for all persons required to be listed. Report compensation for the calendar year ending with or within the organization's tax year.

- List all of the organization's current officers, directors, trustees (whether individuals or organizations), regardless of amount of compensation. Enter - 0 - in columns (D), (E), and ( $F$ ) if no compensation was paid.

- List all of the organization's current key employees, if any. See instructions for definition of "key employee."

- List the organization's five current highest compensated employees (other than an officer, director, trustee, or key employee) who received reportable compensation (Box 5 of Form W-2 and/or Box 7 of Form 1099-MISC) of more than $\$ 100,000$ from the organization and any related organizations.

- List all of the organization's former officers, key employees, and highest compensated employees who received more than $\$ 100,000$ of reportable compensation from the organization and any related organizations.

- List all of the organization's former directors or trustees that received, in the capacity as a former director or trustee of the organization, more than $\$ 10,000$ of reportable compensation from the organization and any related organizations.

List persons in the following order: individual trustees or directors; institutional trustees; officers; key employees; highest compensated employees; and former such persons.

Check this box if neither the organization nor any related organization compensated any current officer, director, or trustee.

(A)

Name and Title

(1)

$(2)$

(3)

(4)

(5)

(6)

(7)

(8)

(9)

(10)

(11)

(12)

(13)

(14)

(B)

Average

hours per

week (list any

hours for

related

organizations

below dotted

line)
(C)

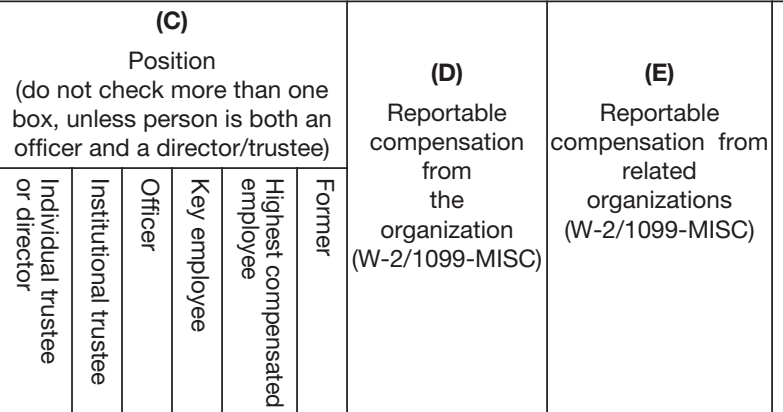

(F)

\section{Estimated} amount of other compensation

from the

organization

and related organizations

(1)

(4)

(5)

(6)

)

(8)

9)

(10)

(11) 
Part VII Section A. Officers, Directors, Trustees, Key Employees, and Highest Compensated Employees (continued)

(A)

Name and title
(B)

Average hours per week (list any

hours for related organizations below dotted line)

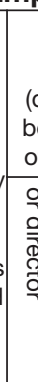

$$
\text { (C) }
$$

(do not check more than one

box, unless person is both an

officer and a director/trustee)

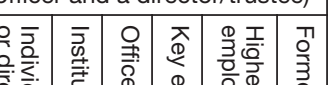

(D)

Reportable compensation

from

the

organization

W-2/1099-MISC)
(F)

Estimated amount of other compensation from the organization and related organizations

(15)

(16)

(17)

(18)

(19)

(20)

(21)

(22)

(23)

$(24)$

$(25)$

$1 b$ Sub-total

d Total (add lines $\mathbf{1 b}$ and 1c)

2 Total number of individuals (including but not limited to those listed above) who received more than $\$ 100,000$ of reportable compensation from the organization

3 Did the organization list any former officer, director, or trustee, key employee, or highest compensated employee on line 1a? If "Yes," complete Schedule $J$ for such individual

4 For any individual listed on line 1a, is the sum of reportable compensation and other compensation from the organization and related organizations greater than $\$ 150,000$ ? If "Yes," complete Schedule $J$ for such individual

5 Did any person listed on line 1a receive or accrue compensation from any unrelated organization or individual for services rendered to the organization? If "Yes," complete Schedule J for such person

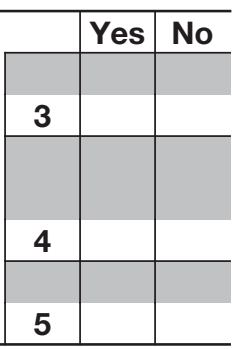

\section{Section B. Independent Contractors}

1 Complete this table for your five highest compensated independent contractors that received more than $\$ 100,000$ of compensation from the organization. Report compensation for the calendar year ending with or within the organization's tax year.

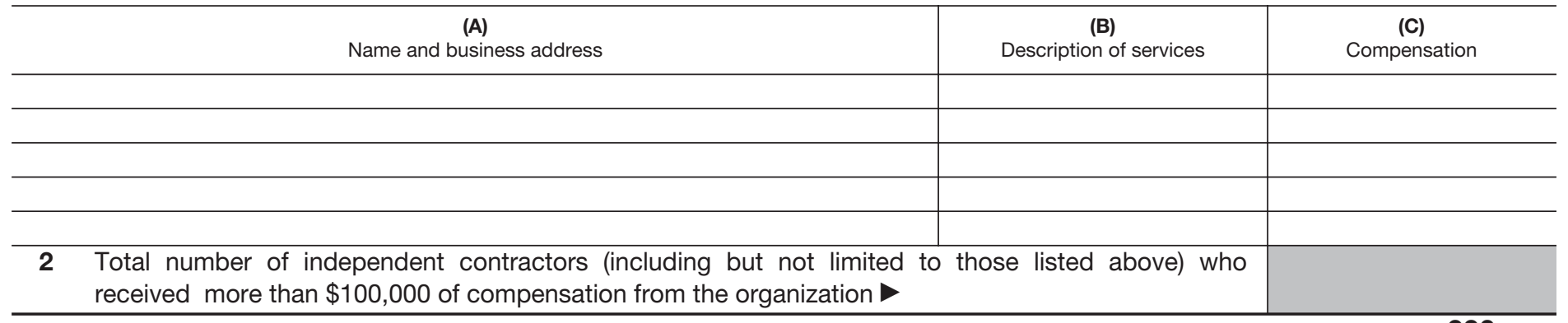




\section{Part VIII Statement of Revenue}

Check if Schedule O contains a response or note to any line in this Part VIII .

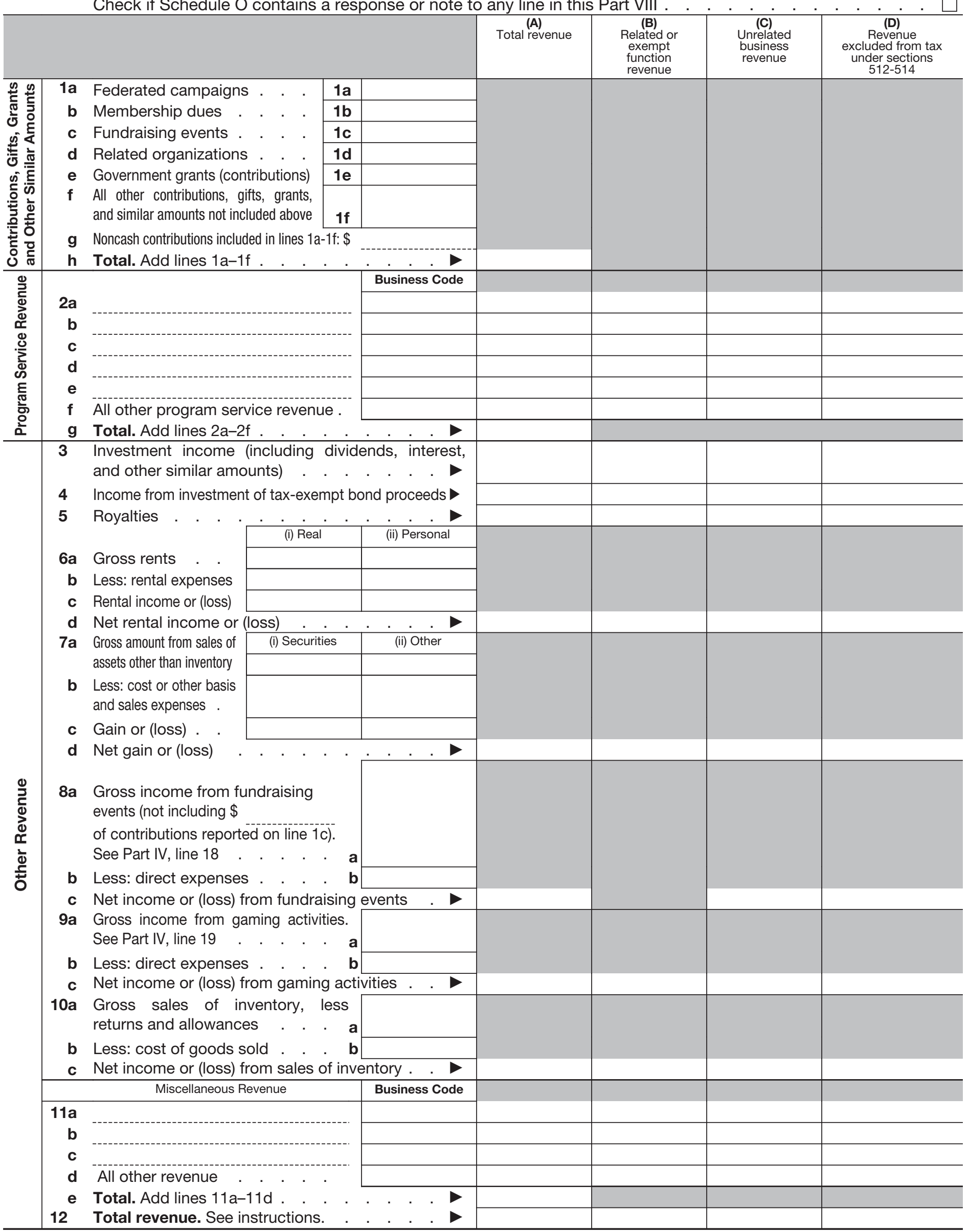


Note: Form SS-4 begins on the next page of this document.

\section{Change to Domestic Employer Identification Number (EIN) Assignment by Toll-Free Phones}

Beginning January 6, 2014, the IRS will refer all domestic EIN requests received by toll-free phones to the EIN Online Assistant. You can access the Assistant by going to www.irs.gov, entering "EIN" in the "Search" feature and following instructions for applying for an EIN online.

\section{Attention \\ Limit of one (1) Employer Identification Number (EIN) Issuance per Business Day}

Effective May 21, 2012, to ensure fair and equitable treatment for all taxpayers, the Internal Revenue Service (IRS) will limit Employer Identification Number (EIN) issuance to one per responsible party per day. For trusts, the limitation is applied to the grantor, owner, or trustor. For estates, the limitation is applied to the decedent (decedent estate) or the debtor (bankruptcy estate). This limitation is applicable to all requests for EINs whether online or by phone, fax or mail. We apologize for any inconvenience this may cause.

\section{Change to Where to File Address and Fax-TIN Number}

There is a change to the Instructions for Form SS-4 (Rev. January 2011). On page 2, under the "Where to File or Fax" table, the address and FaxTIN number have changed. If you are applying for an Employer Identification Number (EIN), and you have no legal residence, principal place of business, or principal office or agency in any state or the District of Columbia, file or fax your application to:

Internal Revenue Service Center

Attn: EIN International Operation

Cincinnati, $\mathrm{OH} 45999$

Fax-TIN: 859-669-5987

This change will be included in the next revision of the Instructions for Form SS-4. 


\section{Form SS-4}

(Rev. January 2010)

Department of the Treasury Internal Revenue Service
Application for Employer Identification Number

(For use by employers, corporations, partnerships, trusts, estates, churches, government agencies, Indian tribal entities, certain individuals, and others.)

See separate instructions for each line.

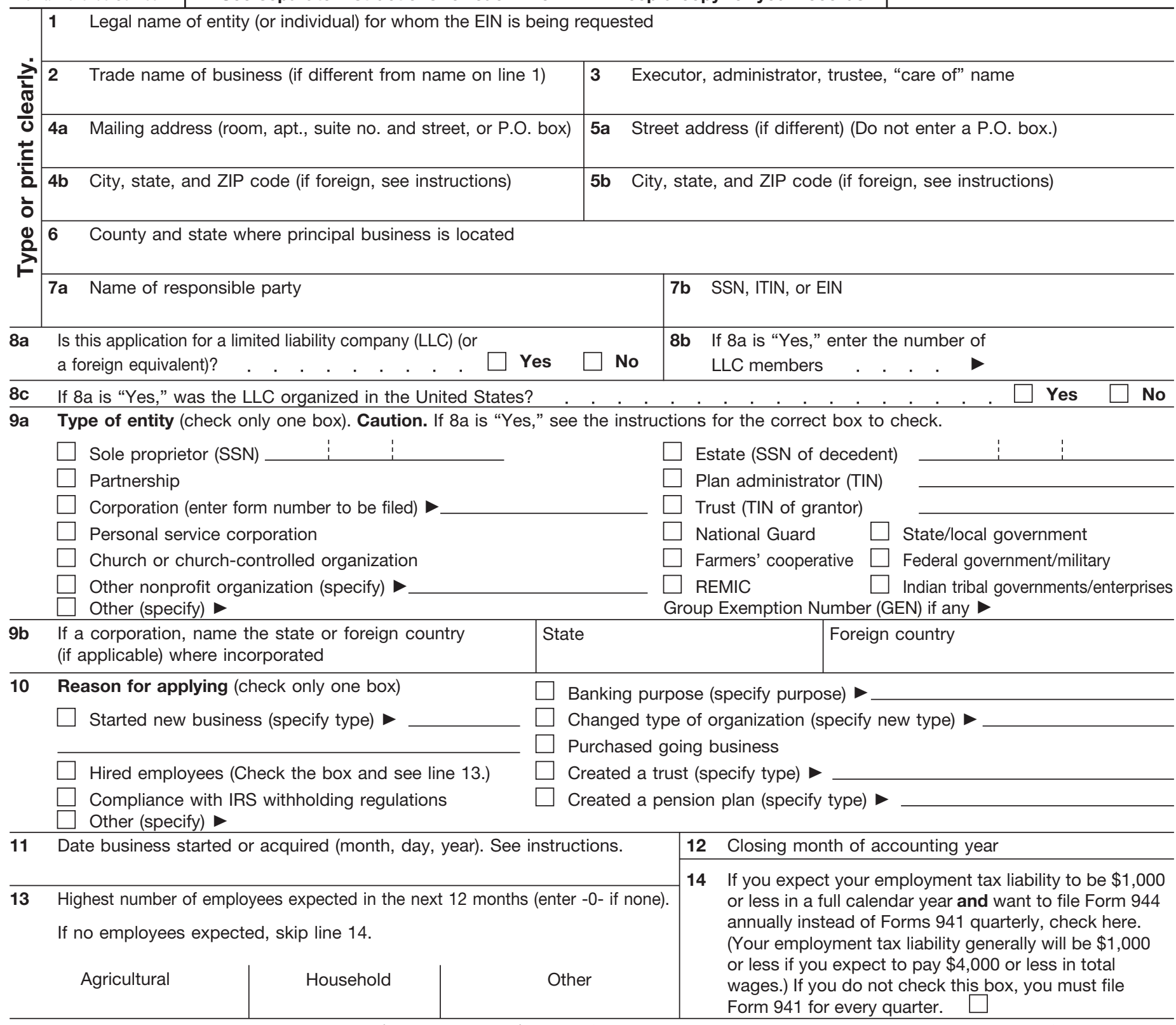

15 First date wages or annuities were paid (month, day, year). Note. If applicant is a withholding agent, enter date income will first be paid to nonresident alien (month, day, year) .

16 Check one box that best describes the principal activity of your business. $\square$ Health care \& social assistance $\square$ Wholesale-agent/broker
$\square$ Construction
$\square$ Rental \& leasing
Transportation \& warehousing
Accommodation \& food service
Wholesale-other
$\square$ Retail
Real estate
Manufacturing
Finance \& insurance
Other (specify)

17 Indicate principal line of merchandise sold, specific construction work done, products produced, or services provided.

$18 \quad$ Has the applicant entity shown on line 1 ever applied for and received an EIN? $\square$ Yes $\square$ No If "Yes," write previous EIN here

\begin{tabular}{l|l|c}
\hline \multirow{3}{*}{$\begin{array}{l}\text { Third } \\
\text { Party } \\
\text { Designee }\end{array}$} & Complete this section only if you want to authorize the named individual to receive the entity's EIN and answer questions about the completion of this form. \\
\cline { 2 - 4 } & Designee's name & Designee's telephone number (include area code) \\
\cline { 2 - 4 } & Address and ZIP code & Designee's fax number (include area code) \\
\hline Under penalties of perjury, I declare that I have examined this application, and to the best of my knowledge and belief, it is true, correct, and complete. & Applicant's telephone number (include area code) \\
Name and title (type or print clearly) & $\left(\begin{array}{c}\text { Applicant's fax number (include area code) } \\
\text { Signature }\end{array}\right.$ & $($ Date
\end{tabular}


